University of Tennessee Health Science Center

UTHSC Digital Commons

\title{
$5-2011$
}

\section{The Design and Synthesis of Autotaxin Inhibitors and Analogs of Lysophosphatidic Acid}

\author{
Renuka Niranjan Gupte \\ University of Tennessee Health Science Center
}

Follow this and additional works at: https://dc.uthsc.edu/dissertations

Part of the Chemicals and Drugs Commons, and the Pharmaceutics and Drug Design Commons

\section{Recommended Citation}

Gupte, Renuka Niranjan, "The Design and Synthesis of Autotaxin Inhibitors and Analogs of Lysophosphatidic Acid" (2011). Theses and Dissertations (ETD). Paper 112. http://dx.doi.org/10.21007/ etd.cghs.2011.0121.

This Dissertation is brought to you for free and open access by the College of Graduate Health Sciences at UTHSC Digital Commons. It has been accepted for inclusion in Theses and Dissertations (ETD) by an authorized administrator of UTHSC Digital Commons. For more information, please contact jwelch30@uthsc.edu. 


\title{
The Design and Synthesis of Autotaxin Inhibitors and Analogs of Lysophosphatidic Acid
}

\author{
Abstract \\ Lysophosphatidic acid (LPA) is a naturally occurring bioactive phospholipid. It has a wide array of \\ biological effects like cell proliferation, survival, migration, apoptosis invasion, wound healing and \\ angiogenesis. Autotaxin (ATX) was identified as an autocrine tumor cell motility factor from A2058 \\ melanoma conditioned medium. ATX has lysophospholipase $D$ enzyme activity and is responsible for the \\ cleavage of lysophophatidylcholine (LPC) leading to the generation of LPA. Antagonists of Autotaxin \\ would have a potential therapeutic application in cancer research. Chapter 1 is an introduction of LPA and \\ autotaxin. It provides the background and significance of the research. Chapter 2 explores the synthesis \\ of the stereoisomers of 3-CCPA and the pharmacological activites of these isomers. Chapter 3 discusses \\ the design and synthesis of benzyl and naphthalene-methyl phosphonic acid inhibitors of autotaxin with \\ anti-invasive and anti-metastatic actions. Chapter 4 elaborates on the search for new non-lipid, drug like \\ LPA analogs. Chapter 5 provides an overview of the work detailed in the dissertation; as well as future \\ directions that will help further the scope of these projects.

\section{Document Type} \\ Dissertation

\section{Degree Name} \\ Doctor of Philosophy (PhD)

\section{Program} \\ Pharmaceutical Sciences

\section{Research Advisor} \\ Duane D. Miller, Ph.D.

\section{Keywords} \\ LPA, Autotaxin.

\section{Subject Categories} \\ Chemicals and Drugs | Medicine and Health Sciences | Pharmaceutics and Drug Design | Pharmacy and \\ Pharmaceutical Sciences

\section{Comments} \\ Two year embargo expired May 2013
}


THE DESIGN AND SYNTHESIS OF AUTOTAXIN INHIBITORS AND ANALOGS OF LYSOPHOSPHATIDIC ACID

\author{
A Dissertation \\ Presented for \\ The Graduate Studies Council \\ The University of Tennessee \\ Health Science Center
}

\begin{abstract}
In Partial Fulfillment
Of the Requirements for the Degree

Doctor of Philosophy

From The University of Tennessee
\end{abstract}

By

Renuka Niranjan Gupte

May 2011 
Copyright (C) 2011 by Renuka N. Gupte All rights reserved 


\section{Dedication}

This dissertation is dedicated to my greatest supporters and idols, my husband and friend Dr.Varun Vaidya and my parents, Mr.Niranjan Gupte and Ms.Savita Gupte. 


\section{Acknowledgements}

I would like to thank my major professor and mentor Dr. Duane D. Miller for giving me a chance to advance professionally and for his support and help throughout this dissertation process. I would also like to thank my dissertation committee members; Dr. Gabor J. Tigyi, Dr. Wei Li, Dr. Isaac O. Donkor and Dr. Richard E. Lee for providing me excellent feedback and also for their continuous encouragement. Without them this dissertation could not have been possible. I give special thanks to Dr.Yan Lu, Dr.Anjaiah Siddam, Dr. Jayprakash Pagadala, Dr. Zhao Wang and Dr.James Fells for their expertise, support, assistance and friendship. I would also like to thank all the members of the "Miller research group", Dr. Charlie Duke, Dr. Renukadevi Patil, Dr.Shivaputra Patil, Dr. Kui Zeng and Mr.Jianjun Chen. I thank all the members of Dr.Tigyis Lab, especially Dr.Yuko Fujiwara and Dr.Dianna Liu. I would also like to extend thanks to our collaborators on the research projects in this dissertation: Dr. Daniel Baker (University of Memphis) and Dr. Abby Parrill (University of Memphis) and their lab members. I would also like to thank Dr. Paul W.Erhardt for allowing me to complete the synthesis of the last few compounds at the University of Toledo. I'd like to thank my family who supported me and kept me encouraged.

The research on autotaxin inhibitors (Chapters 2 and 3) was supported by NIH grant CA92160 (Dr.Tigyi), the Van Vleet Oncology Research Fund (Dr.Tigyi), the Breast Cancer Research Foundation (Dr.Panupinthu) and Lpath Inc. (Dr.Mills). 


\begin{abstract}
Lysophosphatidic acid (LPA) is a naturally occurring bioactive phospholipid. It has a wide array of biological effects like cell proliferation, survival, migration, apoptosis invasion, wound healing and angiogenesis. Autotaxin (ATX) was identified as an autocrine tumor cell motility factor from A2058 melanoma conditioned medium. ATX has lysophospholipase D enzyme activity and is responsible for the cleavage of lysophophatidylcholine (LPC) leading to the generation of LPA. Antagonists of Autotaxin would have a potential therapeutic application in cancer research. Chapter 1 is an introduction of LPA and autotaxin. It provides the background and significance of the research. Chapter 2 explores the synthesis of the stereoisomers of 3-CCPA and the pharmacological activites of these isomers. Chapter 3 discusses the design and synthesis of benzyl and naphthalene-methyl phosphonic acid inhibitors of autotaxin with anti-invasive and anti-metastatic actions. Chapter 4 elaborates on the search for new non-lipid, drug like LPA analogs. Chapter 5 provides an overview of the work detailed in the dissertation; as well as future directions that will help further the scope of these projects.
\end{abstract}




\section{Table of Contents}

Chapter 1. Introduction ................................................................................................................1

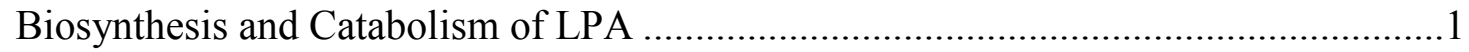

Extracellular Generation of LPA ....................................................................... 2

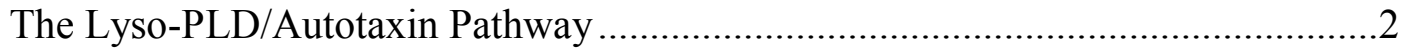

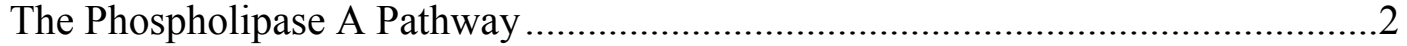

Mild Oxidation of Low Density Lipoprotein ......................................................2

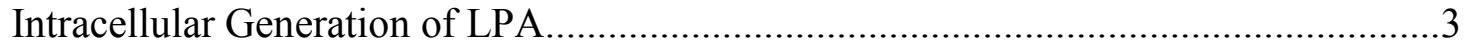

The Glycerophosphate Acyl Transferase (GPAT) Pathway ..................................

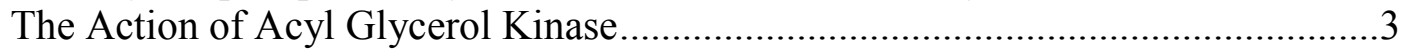

Reduction of Acyl Dihydroxy Acetone Phosphate ..................................................

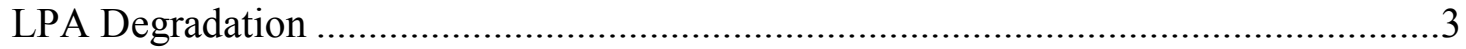

LPA Degradation by Phosphatases ...................................................................

LPA Degradation by Lysophospholipases .................................................... 4

LPA Degradation by Acyltranferases.............................................................. 4

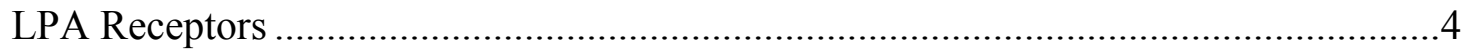

LPA Plasma Membrane GPCR ..................................................................... 4

PPAR $\gamma$ : An Intracellular Receptor of LPA .....................................................

Importance of LPA in Physiological Systems .........................................................5

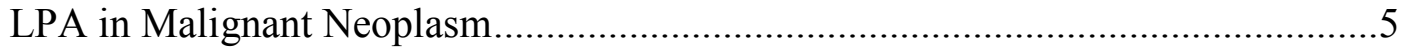

LPA in Nervous System ................................................................................ 6

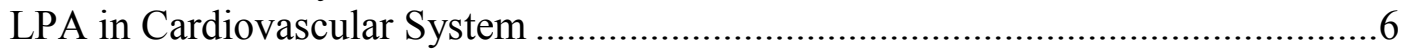

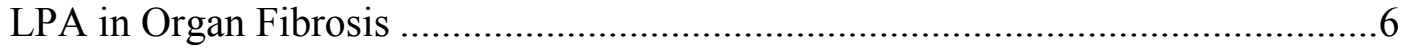

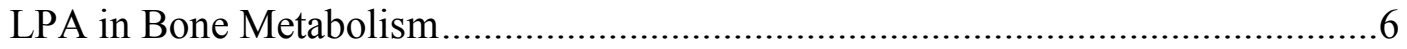

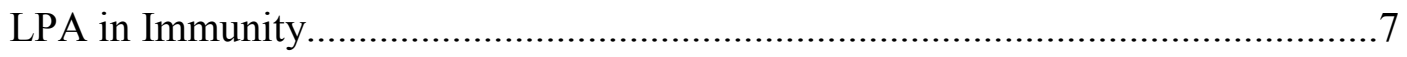

Physiological and Pathological Role of Autotaxin ..................................................

Chapter 2. Synthesis and Pharmacological Evaluation of the Stereoisomers of 3-Carba Cyclic-Phosphatidic Acid ................................................................................10

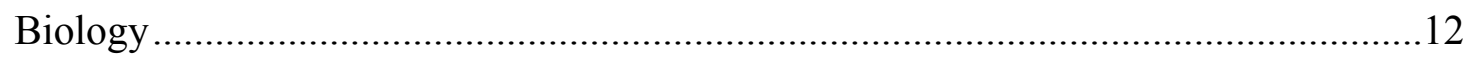

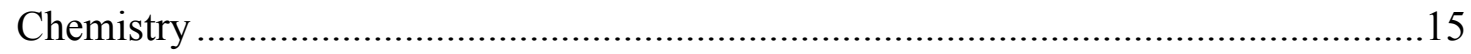

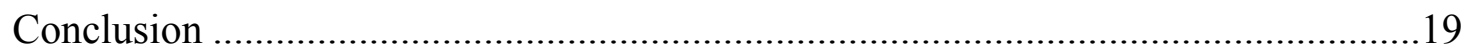

Chapter 3. Benzyl and Naphthalene-Methyl Phosphonic Acid Inhibitors of Autotaxin with Anti-Invasive and Anti-Metastatic Actions .......................................20

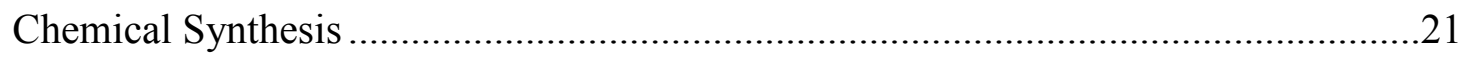

Biological Results ...................................................................................................23

Effect of 4-Substituted Benzyl Phosphonic Acid and 6-Substituted

Naphthalene-2yl-Methyl Phosphonic Acid Derivatives on Autotaxin and

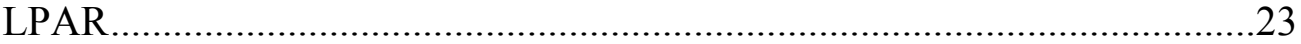

ATX Inhibitors Block Hepatocarcinoma Invasion of Mesothelial and HUVEC

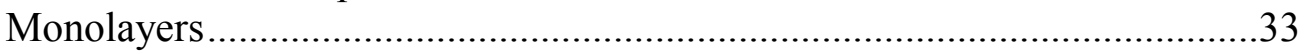

ATX Inhibitors Reduce B16 Melanoma Metastasis In Vivo .................................33 


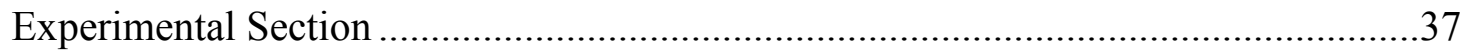

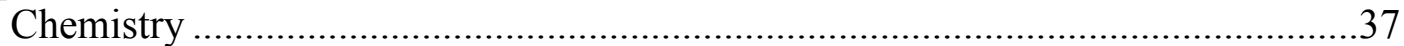

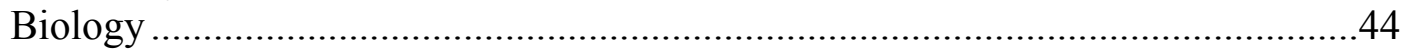

Autotaxin Inhibition Screening Assay ...........................................................44

Determination of the Mechanism of Autotaxin Inhibition ....................................44

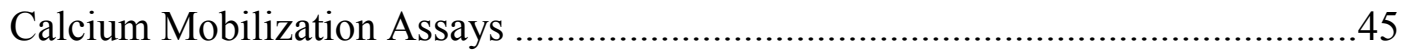

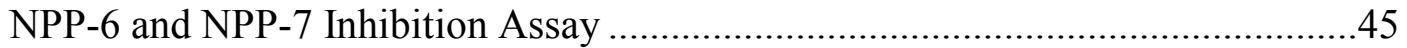

MM1 Hepatoma Cell Invasion of Endothelial Monolayers ..................................45

B16-F10 Murine Melanoma Metastasis Model.....................................................46

Chapter 4. Discovery of Non-Lipid LPA Analogues................................................47

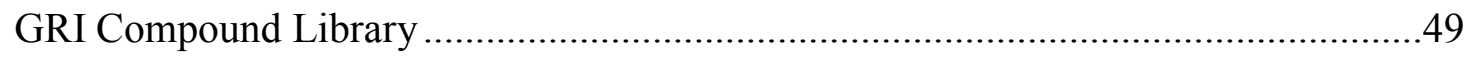

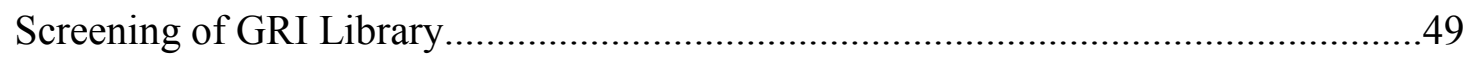

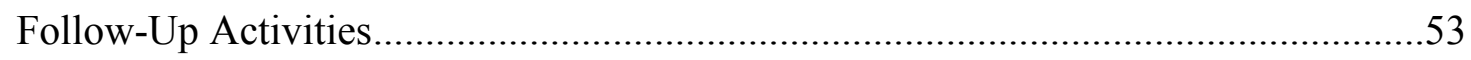

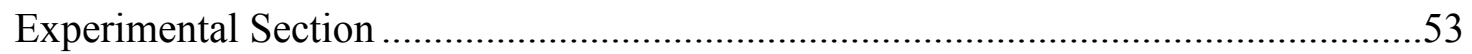

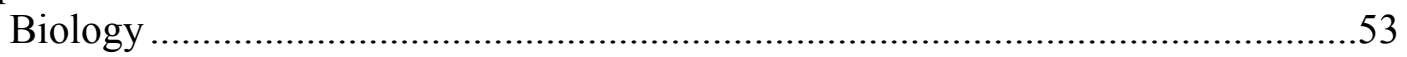

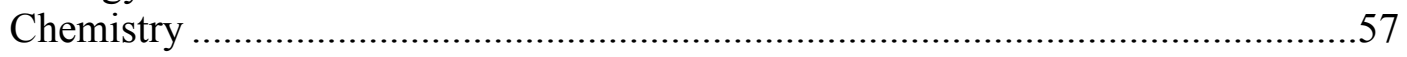

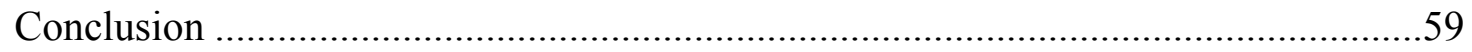

Chapter 5. Discussion of Dissertation ..................................................................................61

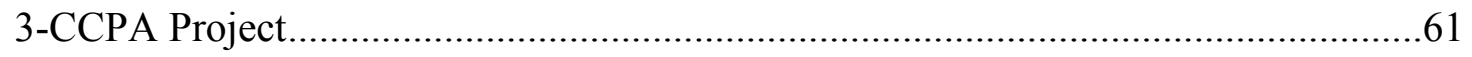

Benzyl and Naphthalene-Methyl Phosphonic Acid Inhibitors of Autotaxin Project....61

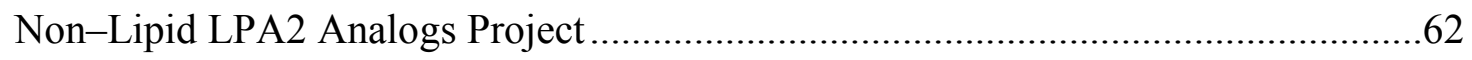

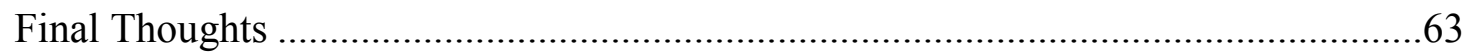

List of References ...............................................................................................................64

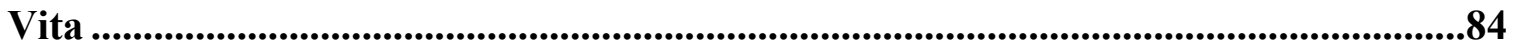




\section{List of Tables}

Table 3.1. Characterization of Benzyl Phosphonic Acids at ATX, NPP6 and NPP7.... 28

Table 3.2. Characterization of Naphthylphosphonic Acids at ATX, NPP6 and

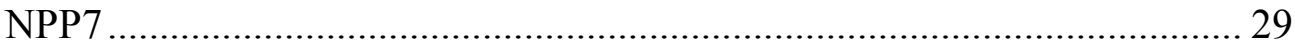

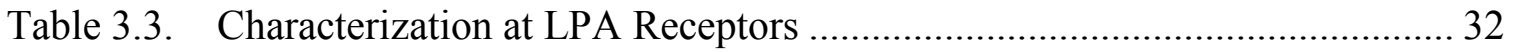

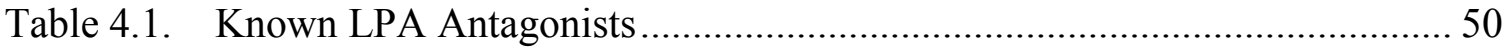

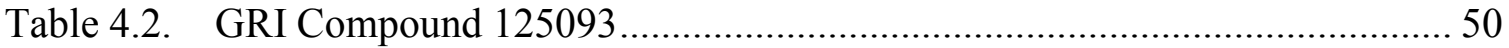

Table 4.3. GRI 977143 Identified as a Lead Compound for LPA 2 Agonist Activity.... 55 


\section{List of Figures}

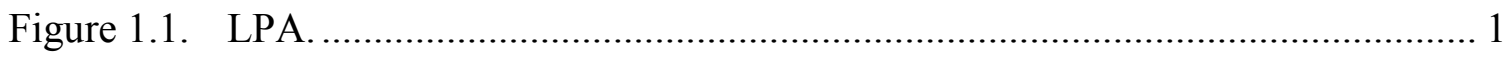

Figure 2.1. Dose Response Relationship of ATX Inhibition by LPA, R-3-CCPA, S-3-CCPA and Racemic-3-CCPA Analogs............................................ 13

Figure 2.2. Dose-Response Relationship of LPA 5 Mediated................................... 14

Figure 2.3. Lack of Stereoselectivity in Lung Metastasis of B16-F10 Melanoma Cells by R-3-CCPA, S-3-CCPA and Racemic-3-CCPA Analogs in a Mouse Model. ...................................................................................... 16

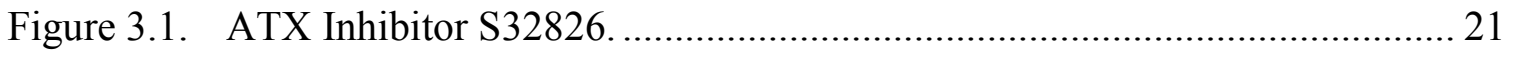

Figure 3.2. Inhibition of ATX-Mediated Hydrolysis of FS3 by LPA, S32826, Compound 30, or $38 \mathrm{~b}$. 30

Figure 3.3. Profiling of LPA Receptor and ATX Transcripts................................... 34

Figure 3.4. Effect of Compound 30, 38b, and LPA-BP on the Lung Metastasis of B16-F10 Melanoma. ....................................................................................... 36

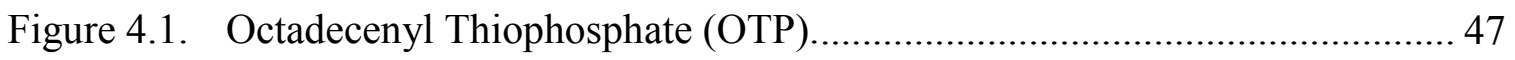

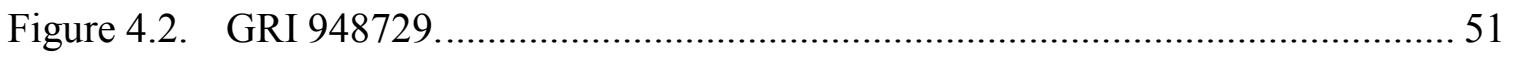

Figure 4.3. Structural Fingerprints for the Similarity Search.................................. 51

Figure 4.4. Similarity Search Protocol................................................................ 52

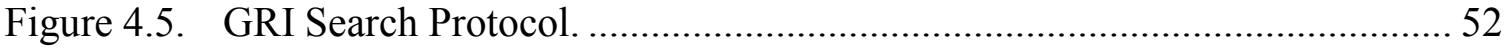




\section{List of Schemes}

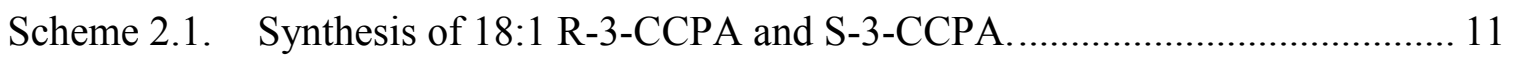

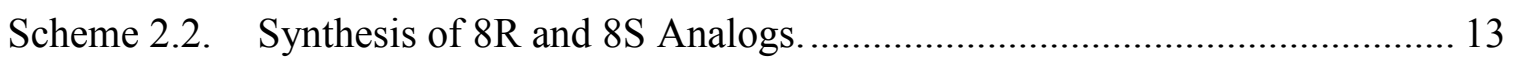

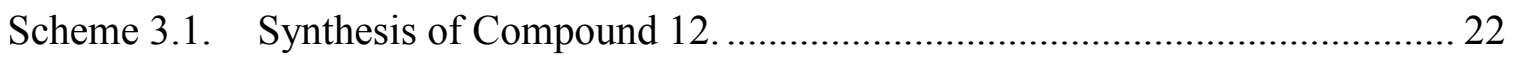

Scheme 3.2. Synthesis of Compound 18......................................................... 22

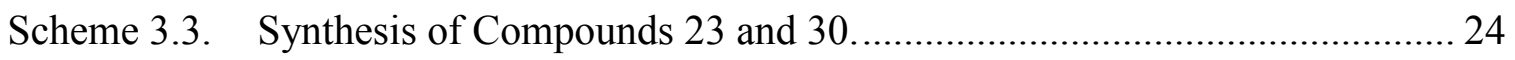

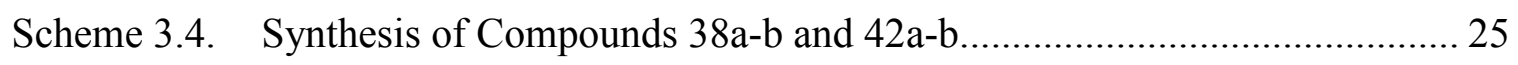

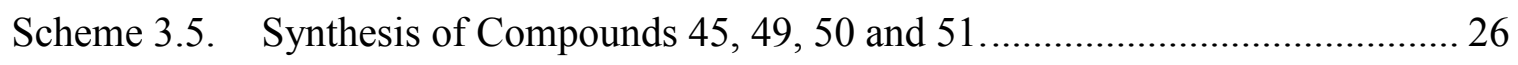

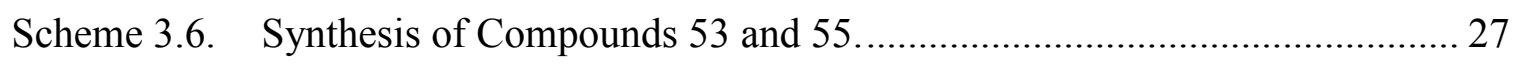

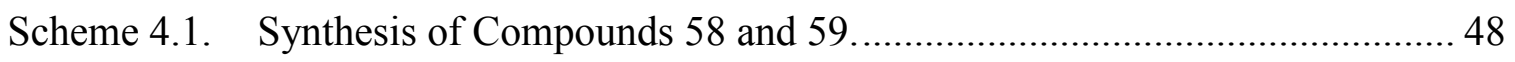

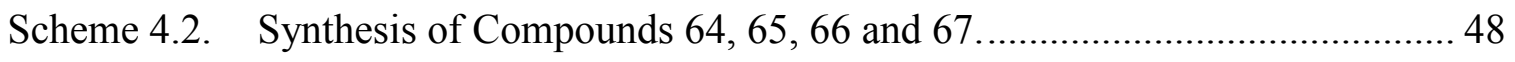

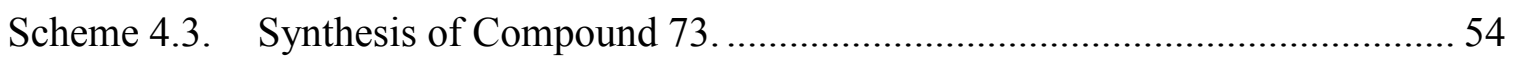

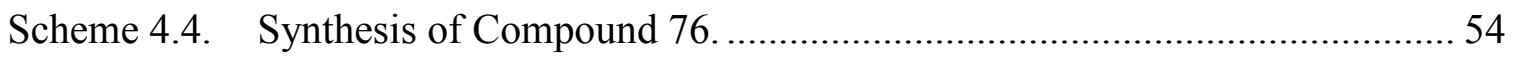

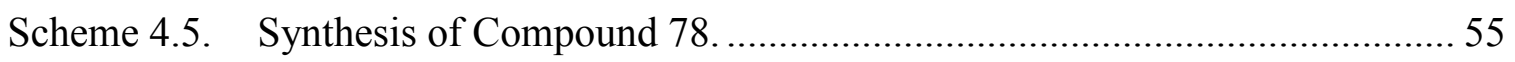

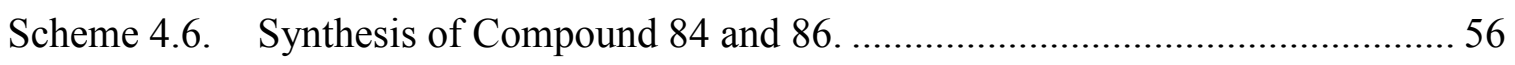




\section{List of Abbreviations}

Acyl DHAP

AGK.

AGPAT.

ATX.

BBB

C1P...

cAMP

CCPA.

CPA.

DCM

DIC.

DMAP

DMEM.

DMF.

DMSO

EDG.

ERK.

ESI-MS

EtOH.

FBS

GPAT.

GPC.

GPCR.

HRMS

LDL

LPA

LPAAT

LPC.

LPP.

LysoPLD

MAG.

MAGK

$\mathrm{MeOH}$

MGAT

moxLDL

MW

NMR

NPP

PA.

PAP-2.

$\mathrm{PC}$

PE.

PLA1
Acyl dihydroxy acetone phosphate

.Acyl glycerol kinase 1-acylglycerol-3-phosphate Autotaxin .Blood brain barrier Ceramide-1-phosphate .Cyclic adenosine monophosphate .Carba cyclic phosphatidic acid .Cyclic phosphatidic acid Dichloromethane Diisopropyl carbodiimide Dimethylamino pyridine Dulbeccos modified eagles medium .Dimethylformamide Dimethyl sulfoxide Endothelial differentiation gene Extracellular signal-regulated kinase Electrospray ionisation mass spectrometry Ethanol .Fetal bovine serum ..Glycerophosphate acyl transferase Glycerophosphoryl choline .G-protein coupled receptors High resolution mass spectrometry .Low density lipoprotein .Lysophosphatidic acid .Lysophosphatidic acid acyl transferase .Lysophosphatidyl choline ..Lipid phosphate phosphohydrolase .Lysophospholipase D .Monoacyl glycerol Monoacyl glycerol kinase Methanol Monoacyl glycerol transferase Mildly oxidized low density lipoprotein ..Molecular weight Nuclear magnetic resonance ...Nucleotide pyrophosphatase/phosphodiesterase Phosphatidic acid .Phosphatidate phosphatases type 2 .Phosphatidyl choline Phosphatidylethanolamine Phospholipase $\mathrm{A}_{1}$ 


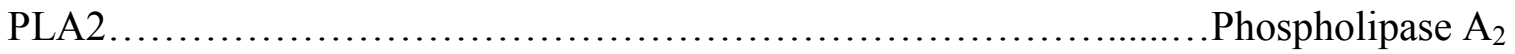

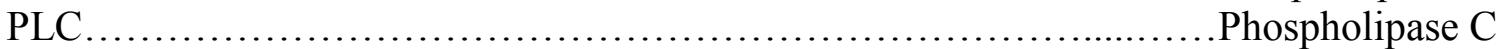

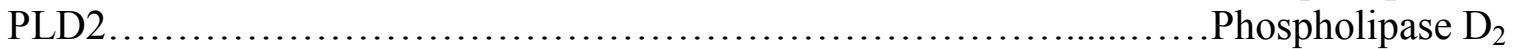

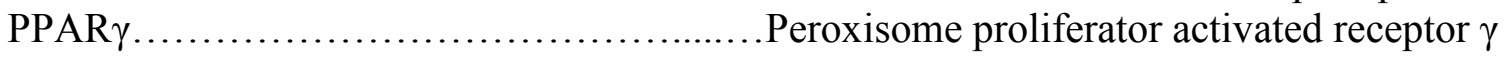

PPTS ............................................... Pyridinium p-toluene sulfonate

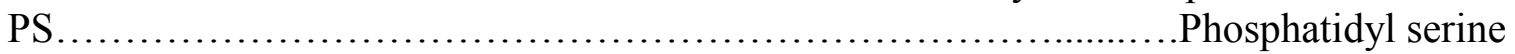

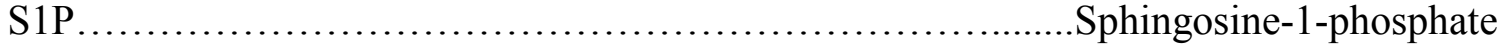

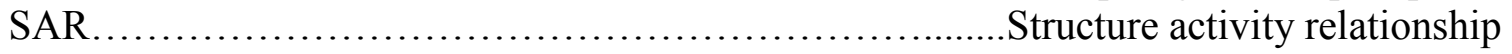

SPC ................................................ Sphingophosphorylcholine

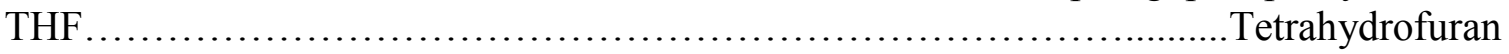

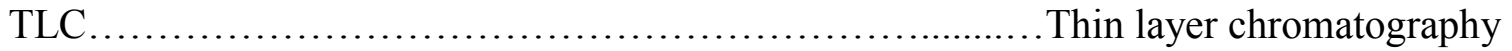

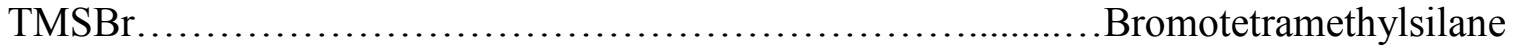




\section{Chapter 1. Introduction}

Lysophosphatidic acid(LPA) is a naturally occurring bioactive phospholipid. It has a wide array of biological effects like cell proliferation, survival, migration, apoptosis invasion, wound healing and angiogenesis. ${ }^{1}$ Lysphosphatidic acid (LPA, Figure 1.1) is a simple phospholipid and consists of a glycerol backbone with a hydroxyl group at the sn-2 (or sn-1) position, a phosphate group at the sn-3 position, and a fatty acid chain at the sn-1 (or sn-2) position. Most of the LPA fatty acids are long chain saturated (16:0, 18:0) or unsaturated $(18: 1,18: 2,20: 4)$ fatty acids linked to the glycerol backbone by acyl or alkyl linkage. Significant levels of LPA have been detected extracelluarly in biological fluids such as serum, ${ }^{2,3}$ sputum, ${ }^{4}$ seminal fluid, ${ }^{5}$ and bronchoalveolar lavage fluid. ${ }^{4}$ In addition, platelets, cancer cells and adipocytes, also generate extracellular LPA. ${ }^{6}$

\section{Biosynthesis and Catabolism of LPA}

LPA can be generated by several different mechanisms. Extracellular LPA is formed catalytically by cleavage of lysophospholipids by lysophospholipase D (lyso-PLD). Extracelular LPA is also generated via secreted PLA enzymes, phosphatidyl serine specific PLA PL $_{1}$ and secretory PLA 2 . Secretory type-II PLA 2 and phosphatidic acid

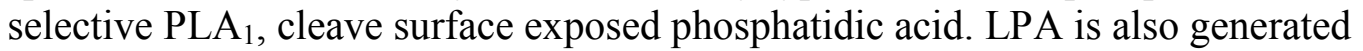
extracellularly by mild oxidation of low density lipoproteins.

The LysoPLD that generates LPA has recently been found to be identical to the cell motility stimulating factor, autotaxin (ATX). ATX also produces cyclic phosphatidic acid (CPA) which is a naturally occuring analog of LPA in which the sn-2 hydroxy group forms a 5-membered ring with the sn-3 phosphate. ${ }^{7}$ In mammalian cells, CPA is generated intracellularly by PLD2 and acts as an inhibitor of PPAR $\gamma .{ }^{8} 3$-carba analogue (3CCPA 18:1) is a selective weak agonist of $\mathrm{LPA}_{5} / \mathrm{GPR} 92$ that fails to activate $\mathrm{LPA}_{1 / 2 / 3 / 4}$ and also inhibits ATX. ${ }^{9,10}$

It is produced intracelluarly by the enzymes glycerophosphate acyltransferase (GPAT), ${ }^{11}$ acylglycerol kinase (AGK) ${ }^{12}$ and by the reduction of acyl dihydroxy acetone phosphate (acyl DHAP) ${ }^{13}$ with the help of a reductase. Major pathway for the intracellular production of LPA was proven to be via $\mathrm{Ca}^{2+}$ independent Phospholipase A2. ${ }^{14}$<smiles>O=C([InH])OC[C@H](O)COP(=O)(O)O</smiles>

Figure 1.1. LPA. 


\section{Extracellular Generation of LPA}

\section{The Lyso-PLD/Autotaxin Pathway}

Autotaxin (ATX) was identified as an autocrine tumor cell motility factor from A2058 melanoma conditioned medium. ${ }^{15}$ ATX has lysophospholipase D enzyme activity and is responsible for the cleavage of lysophophatidylcholine (LPC) leading to the generation of LPA $^{16,17}$ and CPA. ${ }^{18}$ ATX is under feedback inhibition by its hydrolysis products LPA, CPA, and sphingosine-1-phosphate (S1P). ${ }^{19}$ Lyso-PLD generates LPA by hydrolyzing the phosphodiester bond of lysphospholipids, which are formed by the action of PLA 1 and $\mathrm{PLA}_{2}$ on phospholipids.

\section{The Phospholipase A Pathway}

LPA is generated from the hydrolysis of phosphatidic acid (PA) at sn-1 or sn-2 position by $\mathrm{PLA}_{1}$ or $\mathrm{PLA}_{2}$, respectively. Activation of platelets results in LPA production by different mechanisms. Only about $10 \%$ of the total serum LPA is contributed by hydrolysis of PA by PLA enzymes. PLA enzymes can also convert a varitety of phospholipids, e.g., phosphatidylcholine (PC), phosphatidylethanolamine (PE), Phosphatidylserine (PS) with a varying specificity to their corresponding lysolipid forms. Upon activation, platelets release PLA $_{1}$ and PLA $_{2}$ enzymes that generate a de novo pool of lysophospholipids from phospholipids, which serve as substrates for lyso-PLD to generate LPA. ${ }^{20}$ Thus the rate-limiting step in LPA generation in blood is not the hydrolysis of phosphodisterase bond by lyso-PLD, but the release of PLA and PLA $_{2}$ enzymes from platelets and de novo generation of a new lysophospholipids pool. Microvesicles, shed by activated inflammatory cells, have altered membrane asymmetry resulting in accumulation of PA in the outer leaflet of plasma membrane. Secretory or type II PLA 2 released from these microvesicles is involved in LPA production by generating the corresponding lyso-lipids from PE and PC, which upon lyso-PLDmediated hydrolysis result in LPA production. Phospholipase D (PLD) may also be involved in PLA mediated PA-derived LPA production by generating the PA from phospholipids including PC, PE and PS.

\section{Mild Oxidation of Low Density Lipoprotein}

Mild oxidation of low density lipoprotein (mox LDL) generates LPA resulting in its thrombotic and artherogenic actions. LPA also elicits platelet aggregation and intraarterial thrombus formation after the rupture of lipid rich atherosclerotic plaques. ${ }^{21}$ 


\section{Intracellular Generation of LPA}

The Glycerophosphate Acyl Transferase (GPAT) Pathway

LPA is a key intermediate in the synthesis of phospholipids and triglycerides in many cell types. GPAT which is located in the endoplasmic reticulum and in the mitochondria, catalyzes, the acylation of glycerol 3-phosphate generating LPA.

\section{The Action of Acyl Glycerol Kinase}

Phosphorylation of monoacylglycerol (MAG) by MAGK in the inner leaflet of the plasma membrane results in LPA formation. MAGK has also been proposed to be involved in the formation of arachidonyl-LPA in platelets. Similar to GPAT pathway, LPA produced by MAGK pathway also contributes to the intracellular LPA pool.

\section{Reduction of Acyl Dihydroxy Acetone Phosphate}

Intracellular LPA can also be synthesized by reduction of acyl DHAP in peroxisomes. Pancreatic islets when exposed to high glycose concentrations are shown to form LPA utilizing this pathway.

\section{LPA Degradation}

The degradation of LPA occurs in three different pathways as discussed below.

\section{LPA Degradation by Phosphatases}

LPA is dephosphorylated to form MAG by phosphatases that belong to phosphatidate phosphatases type2 (PAP-2) that are also known as lipid phosphate phospohydrolase (LPP). ${ }^{22,23}$ There are four isoforms of LPP family, which includes LPP1, LPP1 $\alpha$, LPP2 and LPP3 that have been cloned and characterized in mammals. ${ }^{24-26}$ Although all of these isoforms dephosphorylate LPA and other phospholipids, they show different selectivites for the lipid substrate in vitro. LPP1 has been shown to have the rank order preference of LPA $>$ PA $>$ sphingosine 1-phosphate $(\mathrm{S} 1 \mathrm{P})>$ ceramide 1-phosphate $(\mathrm{C} 1 \mathrm{P}) \cdot{ }^{26,27} \mathrm{LPP} 2$ is selective for PA $>$ C1P $>$ LPA $>$ S1P and LPP3 shows similar activity towards PA and LPA with a preference over C15 and S1P. ${ }^{26}$ LPP1 did not show any stereo selectivity and acyl group selectivity over alkyl group in LPA analogs. ${ }^{28}$ The differential tissue distribution and substrate selectivities of LPP isoforms may be significantly affecting the biological actions of LPA. 


\section{LPA Degradation by Lysophospholipases}

The second pathway of LPA degradation involves the removal of the long chain fattyacyl group of LPA so as to convert LPA to glycerophosphate. Two distinct lysophospholipases with specificity towards LPA and LPC have been characterized currently. ${ }^{29-32}$

\section{LPA Degradation by Acyltranferases}

LPA acyltransferases (LPAAT), also known as 1-acylglycerol 3-phosphate acyltransferases (AGPAT), catalyzes the acylation of LPA to form PA. ${ }^{33-35}$ LPAAT enzymes include transmembrane family of proteins. The LPAAT family enzymes has seven enzymes that have been characterized till date, including, LPAAT $\alpha$, LPAAT $\beta$, LPAAT $\gamma$, LPAAT $\delta$, LPAAT $\varepsilon$, LPAAT $\zeta$, LPAAT $\eta .{ }^{36,37}$ For the synthesis of PA from LPA, two LPAATs (LPAAT1, and 2) have been cloned and characterized. Namely, human LPAAT1 (also called AGPAT1 or LPAAT $\alpha$ ) and human LPAAT2 (also called AGPAT2 or LPAAT $\beta$ ). Human LPAAT1 shows higher activity towards 14:0-, 16:0-, and 18:2-CoAs, while human LPAAT2 prefers 20:4-CoA over 16:0-or 18:0-CoA. ${ }^{37}$

\section{LPA Receptors}

Extracellular LPA exerts its wide array of pharmacological effects through the activation of G-protein coupled receptors (GPCRS). In addition to the GPCR's, LPA also activates the nuclear transcription factor, peroxisome proliferator activated receptor $\gamma(\operatorname{PPAR} \gamma)$.

\section{LPA Plasma Membrane GPCR}

LPA GPCR's have been acknowledged to be in two distinct gene families, namely, the endothelial gene (EDG) family and the P2Y gene cluster. ${ }^{38}$ The EDG family encodes GPCR's specific to LPA and Sphingosine 1 phosphate (S1P). ${ }^{38}$ The first three LPA receptors, viz. $\mathrm{LPA}_{1}, \mathrm{LPA}_{2}$ and $\mathrm{LPA}_{3}$ belong to the EDG family. These three receptors share $45-56 \%$ of their amino acid identity. ${ }^{38,39}$ Whereas, LPA 4 , LPA, GPR87, P2Y5 and $\mathrm{P} 2 \mathrm{Y} 10$ are the members of the P2Y gene cluster. ${ }^{38} \mathrm{LPA}_{4}$ and $\mathrm{LPA}_{5}$ share $20-24 \%$ amino acid identity. ${ }^{40}$

$\mathrm{LPA}_{1-2}$ are ubiquitously present. LPA is their endogeneous ligand and activator. $\mathrm{LPA}_{1} / \mathrm{EDG} 2 / \mathrm{vzg}-1$ was the first reported LPA receptor. ${ }^{41,42} \mathrm{LPA}_{1}$ mediates its intracellular responses through the interaction with $\mathrm{G}_{\mathrm{i} / \mathrm{o}}, \mathrm{G}_{\mathrm{q}}$ and $\mathrm{G}_{12 / 13}$ proteins. ${ }^{43}$ The cellular effects mediated by $\mathrm{LPA}_{1}$ include the inhibition of adenyl cyclase, ${ }^{41}$ stimulation of Rho signaling, ${ }^{44}$ activation of serum response factor, ${ }^{45}$ Phospholipase C (PLC), ERK, Akt, Rac, DNA synthesis, $\mathrm{Ca}^{2+}$ signaling. ${ }^{46} \mathrm{LPA}_{2}$ shares $60 \%$ amino acid identity with $\mathrm{LPA}_{1} \cdot{ }^{47}$ Analogous to $\mathrm{LPA}_{1}, \mathrm{LPA}_{2}$ also is associated with $\mathrm{G}_{\mathrm{i} / \mathrm{o}}, \mathrm{G}_{\mathrm{q}}$ and $\mathrm{G}_{12 / 13}$ proteins that mediate inhibition of adenyl cyclase, stimulation of Rho signaling, activation of PLC, 
ERK, Akt and intracellular $\mathrm{Ca}^{2+}$ signaling. ${ }^{48,49} \mathrm{LPA}_{3}$ shows approximately $50 \%$ amino acid sequence homology with $\mathrm{LPA}_{1}$ and $\mathrm{LPA}_{2}$. LPA3 is associated with $\mathrm{G}_{\mathrm{i} / \mathrm{o}}$ and $\mathrm{G}_{\mathrm{q}}$ proteins that mediate activation of PLC, ERK and $\mathrm{Ca}^{2+}$ signaling and $\mathrm{LPA}_{3}$ has also been reported to stimulate and inhibit the adenyl cyclase. ${ }^{43,49}$

$\mathrm{LPA}_{4}$ shows a wide tissue distribution with high levels in ovary, uterus and placenta. ${ }^{40} \mathrm{It}$ mediates intracellular responses via $\mathrm{G}_{\mathrm{q}}$ and $\mathrm{G}_{12 / 13}$ proteins that mediate the activation of cyclic AMP. ${ }^{50-52} \mathrm{LPA}_{5}$ shows high expression in the CD8 ${ }^{+}$lymphocytes, B cells, platelets and the dorsal root ganglion cells and is associated with $\mathrm{G}_{\mathrm{q}}$ and mediates the activation of cAMP. ${ }^{51-53}$ Squamous cell carcinomas showed a high expression of GPR87. ${ }^{54-56}$ GPR87 mediates cellular responses via $\mathrm{G}_{\mathrm{q}}$ and $\mathrm{G}_{16}$ proteins. $\mathrm{P} 2 \mathrm{Y} 5$ was found to be expressed in Henley and Huxley layers of the scalp hair follicles. ${ }^{57}$ The cellular responses are mediated through $\mathrm{G}_{\mathrm{q}}, \mathrm{G}_{\mathrm{s}}$ and $\mathrm{G}_{12 / 13}$ by stimulating cAMP. ${ }^{58} \mathrm{P} 2 \mathrm{Y} 10$ was detected in uterus, brain, prostate, lung, placenta, skeletal muscles and brain cells and it is associated with the RhoA-ROCK signaling axis mediated through $\mathrm{G}_{\mathrm{q}}$ and $\mathrm{G}_{16}{ }^{59}$

\section{PPAR $\gamma:$ An Intracellular Receptor of LPA}

Peroxisome proliferator activated receptor $\gamma(\operatorname{PPAR} \gamma)$ is a nuclear receptor for LPA that exhibits its activity intracellularly. ${ }^{60}$ The PPAR family consists of three members PPAR $\alpha$, PPAR $\beta / \delta$ and PPAR $\gamma .{ }^{61}$ LPA induced activation of PPAR $\gamma$ appears to be an important step in the regulation of adipogenesis, macrophage function, neointima formation, and atherogenesis. ${ }^{38,62}$

\section{Importance of LPA in Physiological Systems}

\section{LPA in Malignant Neoplasm}

LPA mediates a plethora of physiological and pathological activities via interactions with a series of high affinity $\mathrm{G}$ protein-coupled receptors (GPCR). LPA is a mitogen, motogen and an anti-apoptotic agent. ${ }^{38}$ Both LPA receptor family members and autotaxin (ATX/LysoPLD), the primary LPA-producing enzyme, are aberrantly expressed in many cancers. The ATX-LPA receptor axis plays a causal role in tumorigenesis and cancerrelated inflammation, further validating the ATX-LPA receptor axis as a rich therapeutic target in cancer. ${ }^{38,63}$ LPA conveys resistance to chemo and radiation therapy through its anti-apoptotic action. ${ }^{64-66}$ The $^{\mathrm{LPA}_{2}}$ receptor is implicated in chemoresistance. ${ }^{65,67-70}$ Siva-1 also binds and sequesters the anti-apoptotic BCL- $X_{L}$ protein and promotes the progression of apoptosis via the mitochondrial pathway. ${ }^{38,71-73}$ LPA induced molecular complex between $\mathrm{LPA}_{2}$ and Siva-1 fosters the anti-apoptotic effect of LPA. ${ }^{38}$ LPA is responsible for the upregulation of matrix metalloprotease (MMP) production, which in turn promotes the proliferation of cancer cells and invasion. ${ }^{38,74-76}$ 


\section{LPA in Nervous System}

LPA and its receptors are involved in maintaining the normal physiology of the nervous system. Both $\mathrm{LPA}_{1}$ and $\mathrm{LAP}_{2}$ are expressed in the central nervous system. ${ }^{77} \mathrm{LPA}$ is important in myelination and Schwann cell survival. ${ }^{38,78-81}$ LPA has also been suggested to modulate the blood-brain barrier (BBB) by enhancing the tight junction permeability in brain-derived endothelial cells. ${ }^{82}$ LPA boosts the formation of cortical folds that leads to the development of gyri in the cerebral cortex.$^{38,83-85}$ LPA is involved in mediating neuropathic pain. ${ }^{38}$ When LPC is injected intrathecally, it has been proven to evoke neuropathic pain and result in de-myelination ${ }^{38,86,87}$ These effects of LPA require ATX and the responsible bioactive compound is LPA which is generated from LPC hydrolysis by ATX. ${ }^{86,88}$

\section{LPA in Cardiovascular System}

LPA seems to be playing a vital role in thrombogenesis and atherogenesis. ${ }^{89,90}$ It has been identified in mox-LDL, human atherosclerotic plaques and the supernatants of activated platelets. ${ }^{20,90}$ LPA and mox-LDL mediates platelets shape change and platelet aggregation in isolated platelets. ${ }^{89}$ LPA that is released upon the rupture of unstable atherosclerotic plaques in vivo, encounter platelets circulating in the blood and cause platelet shape change and aggregation, ultimately leading to the formation of thrombus. ${ }^{21,89}$ In addition to the thrombogenic activity, LPA also has atherogenic properties. LPA increases the endothelial permeability and monocyte adhesion to the endothelium. ${ }^{90-92}$ LPA also increases the vascular tone of the vascular smooth muscle cells in many animal models. ${ }^{90,93,94}$ LPA generation is an important target for manipulating pathological angiogenesis and thrombosis. ${ }^{38}$

\section{LPA in Organ Fibrosis}

LPA has a mitogenic effect on fibroblasts ${ }^{38,95,96}$ and it also increases connective tissue growth factor production contributing to tissue fibrosis. ${ }^{38,97-99}$ LPA has been implicated in renal, ${ }^{38,100}$ hepatic, ${ }^{38,101,102}$ and pulmonary fibrosis. ${ }^{38,103,104}$ In several pharmacological models, the inhibition of $\mathrm{LPA}_{1}$ receptor inhibits the progression of fibrosis. ${ }^{38} \mathrm{LPA}_{1}$ receptor antagonist based therapies would provide a therapeutic management of fibrosis. ${ }^{38,100,103}$

\section{LPA in Bone Metabolism}

LPA has also been identified as a mitogen for osteoblasts. ${ }^{38,105-108}$ It has been shown to prevent osteoblasts apoptosis ${ }^{109}$ and stimulate alkaline phosphatase expression ${ }^{110}$ and cell migration. ${ }^{38} \mathrm{LPA}$ is also shown to be a potent stimulator of dendrite outgrowth, which is inhibited by $\mathrm{LPA}_{1} / \mathrm{LPA}_{3}$ antagonist Ki16425 and pertusis toxin. ${ }^{38,111}$ Pharmacological 
manipulation of LPA receptors may pave a way to preventing bone loss and bone metastasis of cancers. ${ }^{38}$

\section{LPA in Immunity}

The cellular markers of immune responses like, T lymphocytes, ${ }^{112} \mathrm{~B}$ cells, ${ }^{113-115}$ eosinophils, ${ }^{116}$ neutrophils, ${ }^{117}$ macrophages, ${ }^{118}$ mast cells, ${ }^{119}$ and dendritic cells, ${ }^{120-122}$ express LPA receptors. ${ }^{38}$ Natural killer cells act in response to LPA by chemotaxis and increased production of IFN $\gamma .{ }^{38,123-125}$ LPA differentially regulates the development of CD1 dendritic cells. CD-1 molecules are involved in the T cell recognition of self lipids. ${ }^{38,126-128} \mathrm{CD} 1$ restricted $\mathrm{T}$ cells mediate defence mechanisms and pro-inflammatory responses in case of autoimmune diseases like lupus erythematodes, ${ }^{129}$ multiple sclerosis ${ }^{130}$ and autoimmune thyroditis ${ }^{131}$ in host. ${ }^{38}$

\section{Physiological and Pathological Role of Autotaxin}

Autotaxin (ATX) was identified as an autocrine tumor cell motility factor from A2058 melanoma conditioned medium. ${ }^{15}$ ATX has lysophospholipase D enzyme activity and is responsible for the cleavage of lysophophatidylcholine (LPC) leading to the generation of $\mathrm{LPA}^{16,17}$ and CPA. ${ }^{18}$ High levels of autotaxin are generated in a wide variety of metastatic human tumor cell lines including human teratocarcinoma, ${ }^{132}$ hepatocellularcarcinoma, ${ }^{133}$ metastatic breast cancer, ${ }^{134}$ ovariancancer, ${ }^{135}$ thyroid carcinoma, ${ }^{136}$ prostate cancer, ${ }^{137}$ follicular lymphoma ${ }^{138}$ and glioblastomamultiforme. ${ }^{139}$ ATX plays an important role in the chemotherapeutic resistance of breast ${ }^{140}$ and ovarian cancer cells. ${ }^{135}$ ATX is under feedback inhibition by its hydrolysis products LPA, CPA, and sphingosine-1-phosphate (S1P). ${ }^{19}$ Lyso-PLD generates LPA by hydrolyzing the phosphodiester bond of lysphospholipids, which are formed by the action of PLA $\mathrm{P}_{1}$ and $\mathrm{PLA}_{2}$ on phospholipids. Two groups independently reported purifying lyso-PLD, which unexpectedly is identical to autotaxin (ATX), a $125 \mathrm{kDa}$ glycoprotein that stimulates tumor cell motility. ATX was originally isolated from human melanoma cells and was implicated in the metastatic and invasive potential of cancer cells and angiogenesis in various cell types. ATX-deficient mice die at embryonic day 9.5 with profound vascular defects in the yolk sac and embryo.

Molecular cloning of ATX revealed that ATX/Lyso-PLD is a member of nucleotide pyrophosphatase/phosphodiesterase (NPP) family, which includes NPP1, NPP2, NPP3, NPP4, NPP5, NPP6, and NPP7. ATX possesses NPP ativity to hydrolyze nucleosides such as ATP and ADP generating nucleoside 5'-monophosphate and ATX is categorized as NPP-2. NPP-2 is the only PLD in NPP family and it catalyzes production of lysophosphatidic acid (LPA) in extracellular fluids. NPP-1, 2 and 3 catalyse the hydrolysis of pyrophoshphate and phosphodiester bonds in a two step mechanism in which two essential divalent metal ions are required for the formation of a nucleotidylated active site threonine intermediate and the subsequent release of nucleoside 5'-mono-phosphate. NPP members have been localized in different cellular 
compartments and are differentially targeting the plasma membranes of polarized cells, suggesting specific roles of NPP's in cells and tissues. Human NPP-1 is highly expressed in bone and cartilage cells with intermediate expression in heart,liver, placenta and testis. ${ }^{141}$ NPP-3 promotes differentiation and invasion of glial cells. The function of NPP-4 and NPP-5 is unknown. NPP-6 and NPP-7 are choline specific phospholipase C. NPP-6 converts LPC to monoacylglycerol and phosphocholine and also hydrolyses sphingophosphorylcholine (SPC) and glycerophosphorylcholine (GPC). NPP-7 is identical to alkaline sphingomyelinase (alk-Smase) which hydrolyzes sphingomyelin to generate ceramide in the intestinal tract protecting the mucosa of inflammation and tumorogenesis. ${ }^{142}$

As described earlier, there is a growing body of evidence that links ATX to cancer. ATX boosts aggressiveness, metastasis, angiogenesis in malignancies and also is proven to increase the resistance to chemotherapeutic agents. ATX-LPA axis is a promising therapeutic target for the management of cancer.

Chapter 2 includes the stereospecific synthesis of 3-CCPA. Cyclic phosphatidic acid (CPA) is a naturally occurring analog of lysophosphatidic acid (LPA) in which the sn-2 hydroxy group forms a 5-membered ring with the sn-3 phosphate. Here we describe the synthesis of R-3-CCPA and S-3-CCPA along with their pharmacological properties as inhibitors of lysophospholipase D/autotaxin, agonists of the LPA ${ }_{5}$ GPCR, and blockers of lung metastasis of B16-F10 melanoma cells in a C57BL/6 mouse model. S-3CCPA was significantly more efficacious in the activation of $\mathrm{LPA}_{5}$ compared to the $\mathrm{R}$ stereoisomer. In contrast, no stereoselective differences were found between the two isomers toward the inhibition of autotaxin or lung metastasis of B16-F10 melanoma cells in vivo. These results extend the potential utility of these compounds as potential lead compounds warranting evaluation as cancer therapeutics.

Chapter 3 focuses on discovery of a potent ATX inhibitor. Autotaxin (ATX, NPP2) is a member of the nucleotide pyrophosphate phosphodiesterase enzyme family. ATX catalyzes the hydrolytic cleavage of lysophosphatidylcholine (LPC) via a lysophospholipase D activity which leads to the generation of the growth factor-like lipid mediator lysophosphatidic acid (LPA). ATX is highly upregulated in metastatic and chemotherapy-resistant carcinomas and represents a potential target to mediate cancer invasion and metastasis. Here we report the synthesis and pharmacological characterization of non-lipid inhibitors of ATX based on the [4-(tetradecanoylamino) benzyl] phosphonic acid scaffold that was previously found to lack sufficient stability in cellular systems. The new 4-substituted benzyl phosphonic acid and 6-substituted naphthalene-2yl-methyl phosphonic acid analogs blocked ATX with $\mathrm{K}_{\mathrm{i}}$ values in the lowmicromolar-nanomolar range through a mixed-mode mechanism of inhibition. None of the compounds tested inhibited the activity of related enzymes (NPP6 and NPP7). In addition, the compounds were evaluated as agonists or antagonists of seven LPA receptor subtypes. Analogs 22 and 30b, the two most potent ATX inhibitors, dose-dependently inhibited the invasion of MM1 hepatoma cells across murine mesothelial and human vascular endothelial monolayers in vitro. Likewise, compounds 22 and 30b significantly reduced lung metastasis of B16-F10 syngeneic mouse melanoma in a post-inoculation 
treatment paradigm. The described 4-substituted benzyl phosphonic acids and 6-substituted naphthalene-2yl-methyl phosphonic acids represent new lead compounds that effectively inhibit the ATX-LPA-LPA receptor axis both in vitro and in vivo.

Chapter 4 focuses on the discovery of non-lipid LPA agents by screening the GRI compound library and ultimately identifying a lead. 


\section{Chapter 2. Synthesis and Pharmacological Evaluation of the Stereoisomers of 3-Carba Cyclic-Phosphatidic Acid*}

Lysophosphatidic acid (LPA) is a pleiotrophic phospholipid growth factor with multiple roles in cancer metastasis and progression. ${ }^{134}$ LPA elicits numerous biological effects including the promotion of cellular survival, mitogenesis, angiogenesis, migration, and cancer invasion that are mediated, at least in part, by specific cell surface $G$ proteincoupled receptors (GPCR) and intracellular targets that include the nuclear hormone receptor peroxisome proliferator-activated receptor (PPAR $\gamma) .{ }^{1}$ Cylic-phosphatidic acid (1-acyl-2,3-glycerophosphate, CPA) is a naturally occurring analog of LPA in which the sn-2 hydroxy group forms a 5-membered ring with the sn-3 phosphate. ${ }^{7} \mathrm{CPA}$ affects numerous cellular functions, including inhibition of cell cycle progression, induction of stress fiber formation, inhibition of tumor cell invasion and metastasis, and regulation of differentiation and survival of neuronal cells. ${ }^{10} \mathrm{CPA}$ is a weak agonist of the $\mathrm{LPA}_{1}$ and $\mathrm{LPA}_{2}$ GPCR. ${ }^{9}$ Substitution of the sn-2 or sn-3 oxygen with a methylene in CPA yields carba-CPA (CCPA), a stabilized analog of CPA. ${ }^{144}$ Previous work has shown that 3-CCPA does not activate the $\mathrm{LPA}_{1-4} \mathrm{GPCR}^{9}$ but is a weak agonist of $\mathrm{LPA}_{5}{ }^{52}$

Autotaxin (ATX) was initially identified as an autocrine tumor cell motility factor from melanoma cell conditioned medium. ${ }^{15}$ ATX has lysophospholipase D enzyme activity and is responsible for the hydrolysis of lysophophatidylcholine leading to the generation of LPA $^{16,17}$ and CPA. ${ }^{145}$ While ATX can also produce sphingosine-1-phosphate (S1P) in vitro, it does not appear to contribute in a major way to S1P production in vivo. High levels of autotaxin are generated by a wide variety of metastatic human tumor cell lines including human teratocarcinoma, ${ }^{132}$ hepatocellularcarcinoma,${ }^{133}$ metastatic breast cancer, ${ }^{134}$ ovariancancer ${ }^{135}$ thyroid carcinoma, ${ }^{136}$ prostate cancer,${ }^{137}$ follicular lymphoma ${ }^{138}$ and glioblastomamultiforme. ${ }^{139}$ ATX also plays an important role in the chemotherapeutic resistance of breast ${ }^{140}$ and ovarian cancer cells ${ }^{135}$ to chemotherapeutic agents. ATX is under feedback inhibition by its hydrolytic products LPA, CPA, and sphingosine-1-phosphate (S1P). ${ }^{19}$ Racemic 2-CCPA and 3-CCPA are potent inhibitors of ATX activity and 3-CCPA has been shown to reduce lung metastasis of B16-F10 melanoma cells injected intravenously into C57BL/6 mice. ${ }^{9}$ We hypothesized that after the synthesis of stereochemically pure isomers 18:1 3-CCPA we would be able to distinguish between differences in the pharmacological activities of the two steroisomers. To further explore the therapeutic utility of 3-CCPA, we synthesized and characterized both the R-3-CCPA and S-3-CCPA.The approach used for the synthesis of the two stereoisomers of 3-CCPA is shown in Scheme 2.1. Dimethylphosphonate derivatives $2 \mathrm{R}$

* This chapter is adapted with permission from Elsevier publishing services. Gupte, R.; Siddam, A.; Lu, Y.; Li, W.; Fujiwara, Y.; Panupinthu, N.; Pham, T. C.; Baker, D. L.; Parrill, A. L.; Gotoh, M.; Murakami-Murofushi, K.; Kobayashi, S.; Mills, G. B.; Tigyi, G.; Miller, D. D. Synthesis and pharmacological evaluation of the stereoisomers of 3-carba cyclic-phosphatidic acid. Bioorg. Med. Chem. Lett. 2010, 20, 7525-7528. 

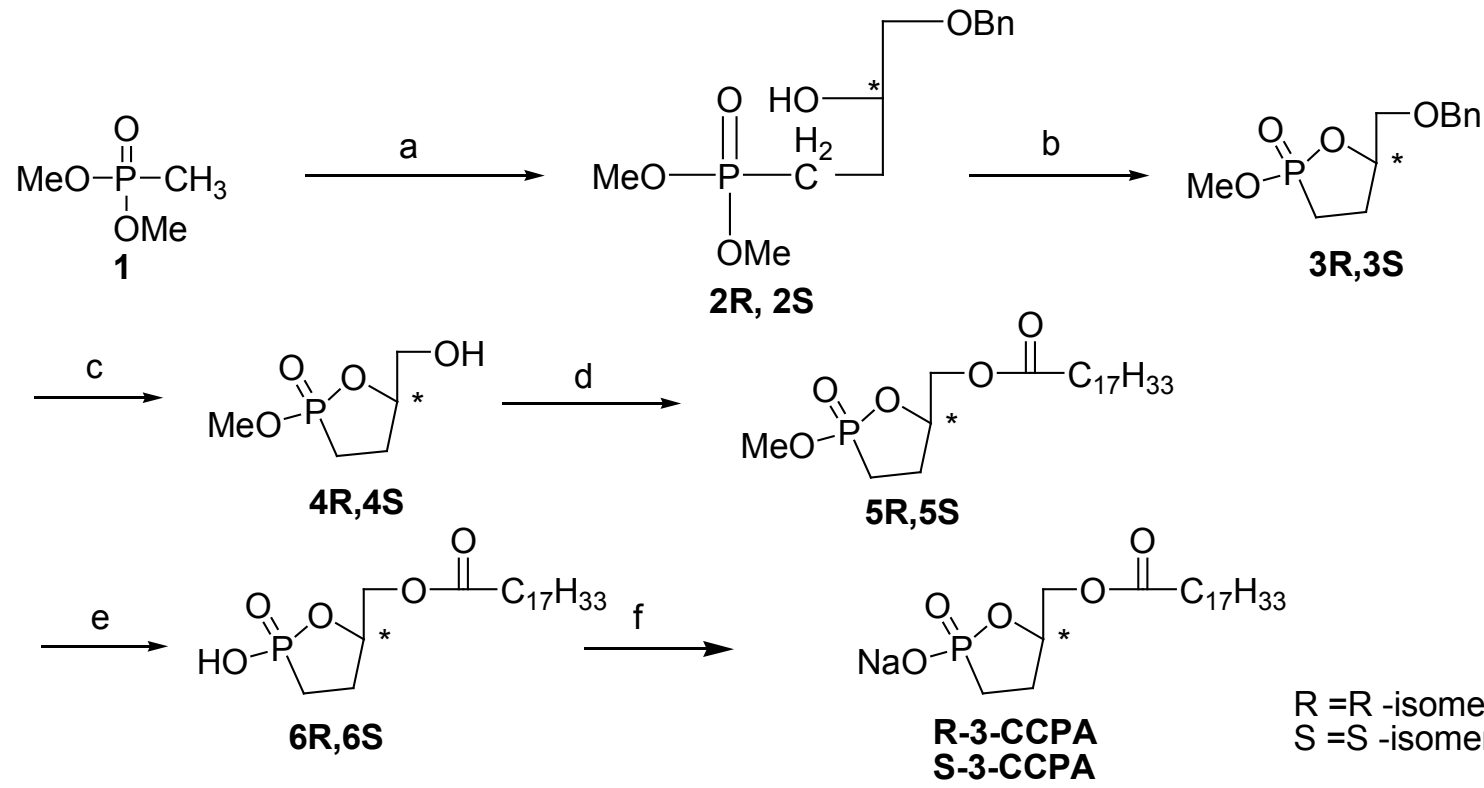

$\mathrm{R}=\mathrm{R}$-isomer
$\mathrm{S}=\mathrm{S}$-isomer

Scheme 2.1. Synthesis of 18:1 R-3-CCPA and S-3-CCPA.

Reagents and conditions: (a)(i) THF, n-BuLi $\left(2.5 \mathrm{M}\right.$ in hexane), $-78^{\circ} \mathrm{C}, 0.5 \mathrm{hr}$; (ii) RBenzyl glycidyl ether (R)/S-Benzyl glycidyl ether (S); (iii) THF, $\mathrm{BF}_{3} \mathrm{OEt}_{2},-78^{\circ} \mathrm{C}, 2 \mathrm{hr}$; (iv)-20 ${ }^{\circ} \mathrm{C}$, 2hr, 68\%; (b) PPTS, Toluene, Reflux, 5hr, 65\%; (c) $\mathrm{H}_{2}, \mathrm{Pd}(\mathrm{OH})_{2} / \mathrm{C}, \mathrm{MeOH}$, $82.5 \%$; (d) $\mathrm{C}_{17} \mathrm{H}_{33} \mathrm{COOH}$, DMAP, DIC, DCM, $18 \mathrm{hr}, 78 \%$; (e) TMSBr, $\mathrm{CH}_{2} \mathrm{Cl}_{2}, 1 \mathrm{hr}, 53 \%$; (f) $0.05 \mathrm{M} \mathrm{NaOH}$. 
and $2 \mathrm{~S}$ were generated from compound 1 using n-butyllithium, $\mathrm{BF}_{3}$ etherate and either the R-or S-isomer of benzylglycidyl ether. The corresponding 3-carbacyclic analogs 3R and $3 \mathrm{~S}$ resulted from treatment with pyridinium $p$-toluenesulfonate (PPTS). Following benzyl group deprotection by hydrogenation, the resulting alcohols $4 \mathrm{R}$ and $4 \mathrm{~S}$ were converted to oleoyl esters 5R and 5S using N,N'-diisopropylcarbodiimide (DIC) and dimethylaminopyridine (DMAP). Final products R-3-CCPA and S-3-CCPA were prepared by methyl group deprotection and conversion to the corresponding sodium salts using $\mathrm{TMSBr}$ and dilute $\mathrm{NaOH}$, respectively. Optical rotations were determined by dissolving the compounds in methanol, to be $+7.3^{\circ}$ for R-3-CCPA and for S-3-CCPA, the optical rotation was $-7.9^{\circ}$. Each compound was purified by silica gel column chromatography and verified by mass spectrometry, NMR and HRMS.

Compounds $3 \mathrm{R}$ and $3 \mathrm{~S}$ were also converted to the benzyl ether derivatives of 3-CCPA as shown in Scheme 2.2. However in the Autotaxin inhibition assay, Compound 8R and 8S failed to show any activity.

\section{Biology}

Compounds R-3-CCPA and S-3-CCPA were examined for their ability to block ATXmediated hydrolysis of FS-3(Echelon Biosciences, Inc. Salt Lake City, UT) using a fluorescence resonance energy transfer-based assay. ${ }^{146}$ Recombinant ATX (25 nmol) in the presence of various concentrations of R-3-CCPA, S-3-CCPA, or LPA 18:1 (positive control) in assay buffer consisting of $1 \mathrm{mM} \mathrm{MgCl}_{2}, 1 \mathrm{mM} \mathrm{CaCl}_{2}, 3 \mathrm{mM} \mathrm{KCl}, 140 \mathrm{mM}$ $\mathrm{NaCl}, 50 \mathrm{mM}$ Tris-HCl, $\mathrm{pH} 8.0$ and $15 \mu \mathrm{M}$ fatty acid free BSA was added to FS-3 (final concentration $1 \mu \mathrm{M}$ ). The ATX inhibition assay was carried out in Dr.Tigyis Laboratory. Assays were performed in white wall 96-well plates (Corning Inc., Corning, NY) and the fluorescence (excitation $485 \mathrm{~nm}$, emission $538 \mathrm{~nm}$ ) was measured at the beginning and after 2 hours of incubation at $37^{\circ} \mathrm{C}$ using a FLEX stationII plate reader (Molecular Devices, Sunnyvale, CA). Data were normalized to the corresponding vehicle control, and the mean \pm standard deviation of triplicate wells was used to calculate ATX activity as per cent of vehicle control (Figure 2.1).

The dose response-relationship of ATX inhibition showed little difference between the R-3-CCPA, S-3-CCPA or the racemate. However, R-3-CCPA was approximately 2 fold more potent in this assay than S-3-CCPA. The kinetic mechanism by which R-3-CCPA and S-3-CCPA inhibited recombinant ATX-mediated hydrolysis of FS-3 were determined by varying the concentration of the substrate (FS-3, ranging from 0.3 to 20 $\mu \mathrm{M})$ in the presence of three concentrations of each inhibitor $\left(0,0.5\right.$ and 2 times the $\left.\mathrm{IC}_{50}\right)$. Simultaneous non-linear regression using WinNonLin ${ }^{\circledR} 6.1$ (Pharsight, Mountain View, CA) was used to fit experimental data and calculate $K_{i}$ and $K_{i}{ }^{\prime}$ using the MichaelisMenten equations for competitive, uncompetitive, mixed-mode, and non-competitive inhibition as we have described in recent work. ${ }^{147-149}$ Mechanism of inhibition was assigned based on the lowest averaged percent residuals for each mechanism derived from curve fitting. Using this procedure R-3-CCPA and S-3-CCPA were determined to be mixed mode ATX inhibitors with $\mathrm{K}_{\mathrm{i}}$ values of 0.8 and $1.6 \mu \mathrm{M}$, respectively. 


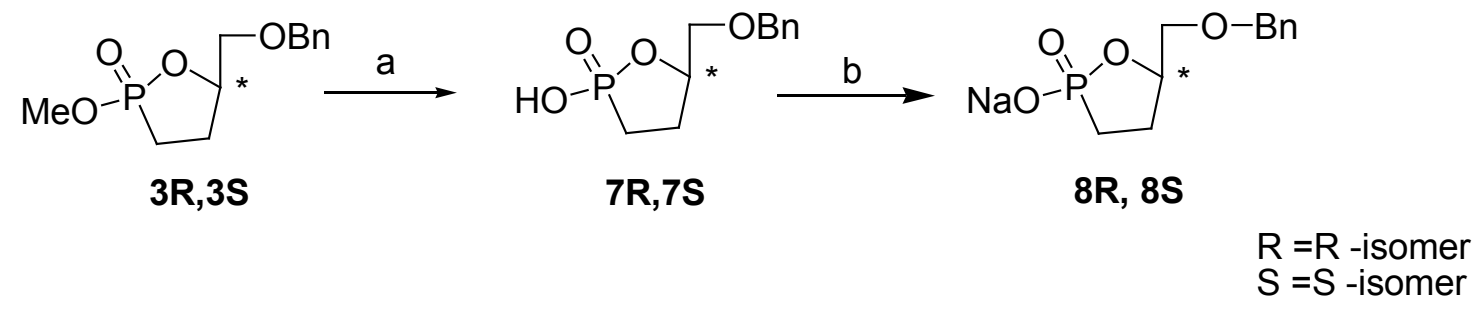

Scheme 2.2. Synthesis of $8 \mathrm{R}$ and $8 \mathrm{~S}$ Analogs.

Reagents and conditions: (a)TMSBr, $\mathrm{CH}_{2} \mathrm{Cl}_{2}, 1 \mathrm{hr}, 53 \%$; (b) $0.05 \mathrm{M} \mathrm{NaOH}$.

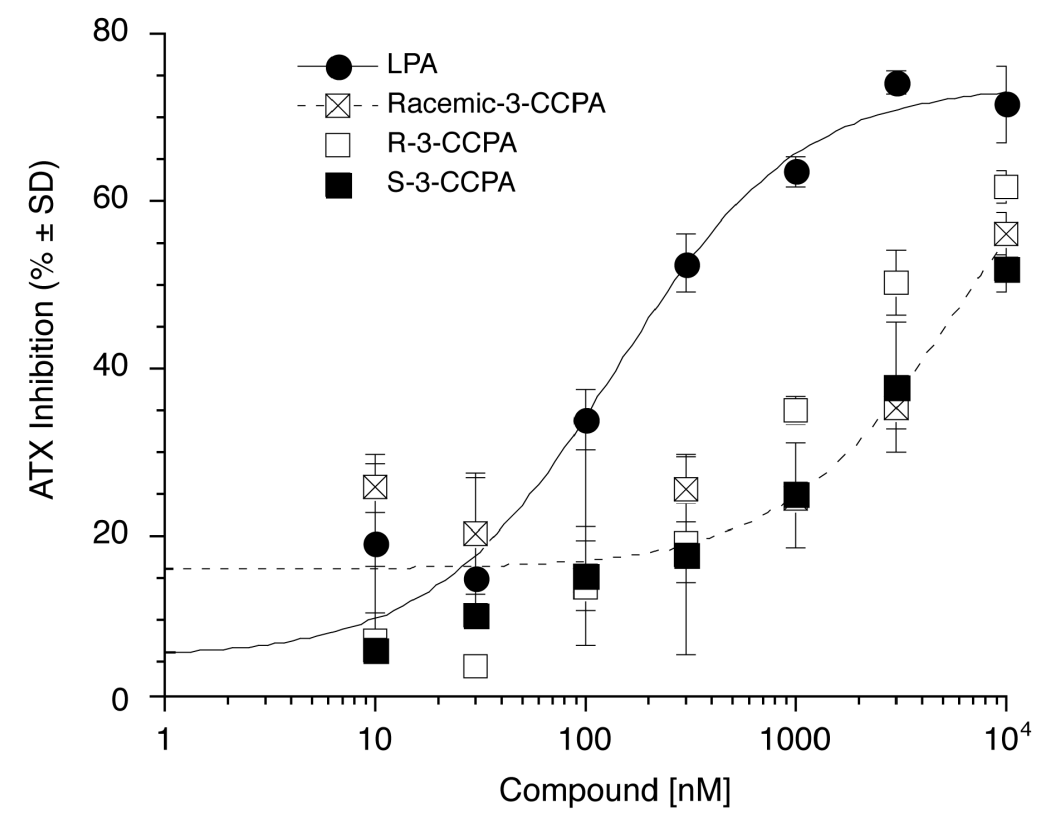

Figure 2.1. Dose Response Relationship of ATX Inhibition by LPA, R-3-CCPA, S-3CCPA and Racemic-3-CCPA Analogs. 
The mechanism of inhibition study was performed by Dr.Bakers group at the University of Memphis. The lack of ligand stereospecificity of the $\mathrm{LPA}_{1}, \mathrm{LPA}_{2}$, and $\mathrm{LPA}_{3}$ receptors has been published previously ${ }^{28}$ but no information of stereoselective ligand acitvitaion for $\mathrm{LPA}_{5}$ is currently available at the present time. Racemic-3-CCPA has previously been shown to be an agonist of the $\mathrm{LPA}_{5}$ GPCR ${ }^{52}$ Here we compared the dose-response curves of $\mathrm{LPA}_{5}$ activation for R-3-CCPA and S-3-CCPA with that of the racemate. These experiments were performed in B103 cells stably expressing $\mathrm{LPA}_{5}$. Wild type B103 cells do not produce $\mathrm{Ca}^{2+}$ transients in response to LPA and are widely used as a host cell for LPA receptor expression studies. B103-LPA 5 cells were loaded with Fura-2AM for 30 min in modified Krebs buffer containing 2\% (v/v) pluronic acid, rinsed with Krebs buffer, and changes in the intracellular $\mathrm{Ca}^{2+}$ concentration were monitored by determining the ratio of emitted light intensities at $520 \mathrm{~nm}$ in response to excitation at 340 and $380 \mathrm{~nm}$ using a FLEX station II plate reader (Molecular Devices, Sunnyvale, CA) ${ }^{150}$ The Activity of the sterioisomers on $\mathrm{LPA}_{5}$ was determined in Dr.Tigyi's Laboratory. Compound S-3-CCPA showed significantly higher $(\mathrm{p}<0.05)$ efficacy than did R-3-CCPA for LPA5-mediated calcium mobilization at concentrations above $1 \mu \mathrm{M}$ (Figure 2.2). Thus, the $\mathrm{LPA}_{5}$ receptor shows a slight stereoselectivity for the S-over the R-stereoisomer which contrasts the weak preference ( $\sim 2$-fold) shown by ATX for the R-isomer.

It has been previously shown that racemic 3-CCPA inhibited lung metastasis of B16-F10 melanoma in a mice model. To extend this observation, the stereoisomers were characterized in this model. ${ }^{9,10}$ This in vivo testing was carried out at the M.D Anderson Cancer Center by Dr. Mills's group. Eight-week-old female C57Bl/6 mice were

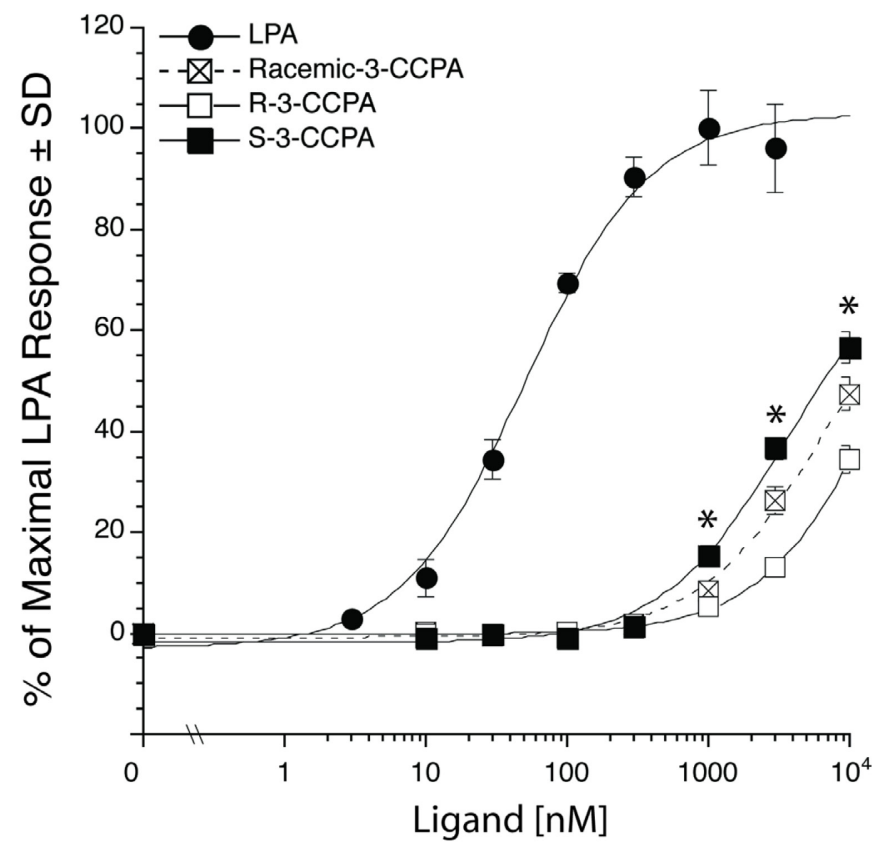

Figure 2.2. Dose-Response Relationship of LPA5 Mediated. 
inoculated with $5 \times 10^{4}$ melanoma cells via the tail vein and divided randomly into 4 groups. The groups then received either saline vehicle, R-3-CCPA, S-3-CCPA, or racemate (at $0.5 \mathrm{mg} / \mathrm{kg}$ intraperitoneally) $30 \mathrm{~min}$ after the B16-F10 inoculation and daily for an additional 10 days. Animals in all groups were monitored for an additional 10 days without further treatments. On day 21, all mice were sacrificed and lungs were dissected, fixed with formalin and the numbers of black melanoma nodules on the lung surface were counted in each sample (Figure 2.3). All 3-CCPA treated groups (R-3-CCPA, S-3-CCPA and Racemic-3-CCPA) significantly reduced the number of lung metastases compared to the vehicle treated group. However, no statistically significant differences were found between the 3-CCPA treated groups using ANOVA followed by Newman-Keuls multiple comparison test.

\section{Chemistry}

All starting materials, reagents and solvents were obtained from commercial suppliers and were used without further purification. Reactions were performed under an inert atmosphere of nitrogen, unless otherwise specified. Routine thin-layer chromatography (TLC) was performed on silica gel plates (Analtech, Inc., 250 microns). Flash chromatography was conducted on silica gel (Merck, grade 60, 230-400 mesh). ${ }^{1} \mathrm{H}$ NMR spectra were recorded on a Bruker ARX 300 spectrometer $(300 \mathrm{MHz})$ or Varian spectrometer $(500 \mathrm{MHz})$ using DMSO- $d_{6}$ and $\mathrm{CDCl}_{3}$ as solvents, and spectral data were consistent with assigned structures. Chemical shift values were reported as parts per million $(\delta)$, coupling constants $(J)$ are given in $\mathrm{Hz}$, and splitting patterns are designated as follows: s, singlet; d, doublet; t, triplet; q, quartet; $m$, multiplet. Optical rotation was measured on AUTOPOL III instrument at $25^{\circ} \mathrm{C}$ and at (wavelength) $\lambda=589$. Mass spectra were collected on a Bruker ESQUIRE electrospray ionization /ion (ESI) trap instrument in the positive and negative modes. High-resolution mass (HRMS) measurements were obtained using a Micromass Q-TOF2 mass spectrometer.

General procedure for the synthesis of $2 \mathrm{R} / 2 \mathrm{~S}$ : To a solution of methylphosphonic acid dimethyl ester $(2.6 \mathrm{ml}, 24.0 \mathrm{mmol})$ in THF $(40 \mathrm{ml})$ in a clean dry flask, was added n-butyllithium $\left(2.5 \mathrm{M}\right.$ solution in hexane) $(14.5 \mathrm{ml}, 24.0 \mathrm{mmol})$ at $-78^{\circ} \mathrm{C}$, and the reaction mixture was stirred for $0.5 \mathrm{~h}$ at $-78^{\circ} \mathrm{C}$. To this mixture was added $\mathrm{BF} 3$ etherate (3.04 ml, $24.0 \mathrm{mmol})$, followed by a solution of (R)-benzylglycidyl ether/(S)benzylglycidyl ether $(1.83 \mathrm{ml}, 12.0 \mathrm{mmol})$ in THF $(10 \mathrm{ml})$. The reaction mixture was stirred for $2 \mathrm{~h}$ at $-78^{\circ} \mathrm{C}$ and then warmed to $-20^{\circ} \mathrm{C}$ and stirred for $2 \mathrm{~h}$. The reaction mixture was quenched by the addition of saturated $\mathrm{NH}_{4} \mathrm{Cl}$, extracted with ethylacetate $(100 \mathrm{ml} \times 3)$ and washed with saturated $\mathrm{NaCl}(50 \mathrm{ml})$. The combined organic layer was dried over anhydrous MgSO4, and the solvent was removed under reduced pressure. The residue was purified by column chromatography on silica gel (eluted with $\mathrm{CHCl}_{3} / \mathrm{MeOH}$ $(30: 1))$ to give compound $2 \mathrm{R}$ or $2 \mathrm{~S}(66 \%-68 \%)$.

2R: ${ }^{1} \mathrm{H}$ NMR (500MHz, DMSO) $\delta=7.350(5 \mathrm{H}, \mathrm{m}) ; 4.819-4.809(1 \mathrm{H}, \mathrm{d}, \mathrm{J}=5) ; 4.482$ (2h, s); 3.614-3.600 (6H, d, J = 7 Hz); 3.376-3.269 (2H, m); 1.187-1.450 (4H, m). MS (ESI) $\mathrm{m} / \mathrm{z} 311.0[\mathrm{M}+\mathrm{Na}]^{+}$. 


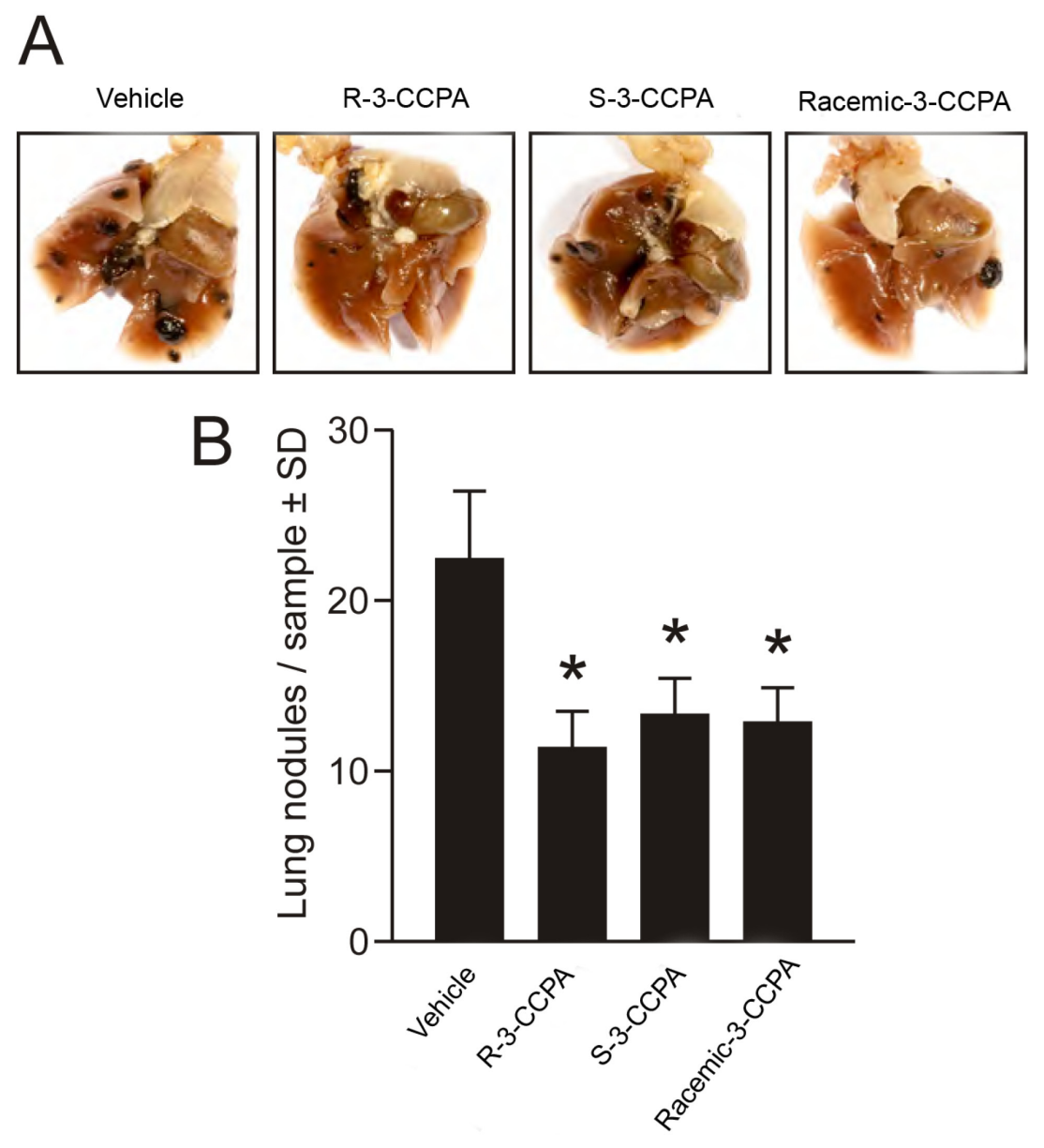

Figure 2.3. Lack of Stereoselectivity in Lung Metastasis of B16-F10 Melanoma Cells by R-3-CCPA, S-3-CCPA and Racemic-3-CCPA Analogs in a Mouse Model.

A) Representative images show fixed intrathoracic organs including lung lobules with visible nodules on the surfaces in black. Total numbers of nodules were reduced in samples treated with $7 \mathrm{R}, 7 \mathrm{~S}$ or racemate compared to vehicle. Scale bar is $0.5 \mathrm{~cm} . \mathrm{B}$ ) Lung nodules of B16-F10 melanoma cells were quantified. The number of lung nodules was significantly decreased in groups treated with R-3-CCPA, S-3-CCPA, and the Racemic-3-CCPA compared to vehicle. However, no statistically significant differences were found either between the stereoisomers or the racemate. Data represent the mean. \pm .SEM, $n=6-8$ mice. ${ }^{*} \mathrm{p}<0.05$ compared to vehicle analyzed by one-way ANOVA followed by Newman-Keuls multiple comparison test. 
2S: ${ }^{1} \mathrm{H}$ NMR (500MHz, DMSO) $\delta=7.36-7.282(5 \mathrm{H}, \mathrm{m}) ; 4.819-4.809(1 \mathrm{H}, \mathrm{d}, \mathrm{J}=5)$; 4.482 (2h, s); 3.614-3.600 (6H, d, J = 7Hz); 3.376-3.269 (2H, m); 1.187-1.450 (4H, m). MS (ESI) m/z $311.0[\mathrm{M}+\mathrm{Na}]$.

General procedure for the synthesis of $3 \mathrm{R} / 3 \mathrm{~S}$ : To a solution of $2 \mathrm{R} / 2 \mathrm{~S}$ (440 $\mathrm{mg}, 1.53$ $\mathrm{mmol})$ in toluene $(20 \mathrm{ml})$ was added a pyridinium p-toluenesulfonate $(1.15 \mathrm{~g}, 4.58$ $\mathrm{mmol}$ ), and the reaction mixture was heated at reflux for $3 \mathrm{~h}$. The mixture was cooled and diluted with ethyl acetate $(100 \mathrm{ml})$. The mixture was washed with saturated $\mathrm{NaCl}(70 \mathrm{ml})$, and the organic layer was dried over anhydrous $\mathrm{MgSO}_{4}$. The solvent was removed under reduced pressure, and the residue was purified by column chromatography on silica gel (300 Mesh) (eluted with $\mathrm{CHCl}_{3} / \mathrm{MeOH}(30: 1)$ ) to give 3R/3S (55\%-58\%).

3R: ${ }^{1} \mathrm{H}$ NMR $\left(300 \mathrm{MHz}, \mathrm{CDCl}_{3}\right) \delta=7.363-7.303(5 \mathrm{H}, \mathrm{m}) ; 4.608(2 \mathrm{~h}, \mathrm{~s}) ; 4.419-4.408(1 \mathrm{H}$, p); 3.816-3.779 (3H, d, J = 11.1Hz); 3.633-3.588 (2H, m); 2.218-1.889 (4H, m). MS (ESI) $\mathrm{m} / \mathrm{z} 257.0[\mathrm{M}+\mathrm{H}] ; \mathrm{m} / \mathrm{z} 279.0[\mathrm{M}+\mathrm{Na}]$.

3S: ${ }^{1} \mathrm{H}$ NMR (500MHz, $\left.\mathrm{CDCl}_{3}\right) \delta=7.378-7.312(5 \mathrm{H}, \mathrm{m}) ; 4.619(2 \mathrm{~h}, \mathrm{~s}) ; 4.419-4.408(1 \mathrm{H}$, p); 3.820-3.798 (3H, d, J = 11Hz); 3.628-3.619 (2H, m); 2.325-1.733 (4H, m). MS (ESI) $\mathrm{m} / \mathrm{z} 257.0[\mathrm{M}+\mathrm{H}] ; \mathrm{m} / \mathrm{z} 279.0[\mathrm{M}+\mathrm{Na}]$.

General procedure for the synthesis of 4R/4S: To a solution of 3R/3S (252 mg, 0.98 mmol) in ethanol $(5 \mathrm{ml})$ was added $20 \% \mathrm{Pd}(\mathrm{OH})_{2} / \mathrm{C}(25 \mathrm{mg})$, and the mixture was stirred under $\mathrm{H}_{2}$ at room temperature for 1 day. The catalyst was removed by filtration and the filtrate was evaporated under reduced pressure. The residue was purified by column chromatography on silica gel (eluted with $\mathrm{CHCl}_{3} / \mathrm{MeOH}(20: 1)$ ) to give $4 \mathrm{R} / 4 \mathrm{~S}(143 \mathrm{mg}$, $0.86 \mathrm{mmol}, 88 \%)$.

4R: ${ }^{1} \mathrm{H}$ NMR $\left(300 \mathrm{MHz}, \mathrm{CDCl}_{3}\right) \delta=4.54-4.3(1 \mathrm{H}, \mathrm{m}) ; 3.824-3.795(3 \mathrm{H}, \mathrm{d}, \mathrm{J}=8.7 \mathrm{~Hz})$; 3.639-3.623 (2H, m); 2.4-1.951 (4H, m). MS (ESI) m/z 188.9 [M + Na].

4S: ${ }^{1} \mathrm{H}$ NMR $\left(500 \mathrm{MHz}, \mathrm{CDCl}_{3}\right) \delta=4.509-4.473(1 \mathrm{H}, \mathrm{m}) ; 3.825-3.803(3 \mathrm{H}, \mathrm{d}, \mathrm{J}=11 \mathrm{~Hz})$; 3.649-3.602 (2H, m); $2.640(1 \mathrm{H}, \mathrm{s}) ; 2.310-1.900(4 \mathrm{H}, \mathrm{m})$. MS (ESI) m/z 188.9 [M + Na].

General procedure for the synthesis of $5 \mathrm{R} / 5 \mathrm{~S}$ : To a solution of palmitic acid $(0.288 \mathrm{~g}$, $1.018 \mathrm{mmol})$ in dry $\mathrm{CH}_{2} \mathrm{Cl}_{2}(5 \mathrm{ml})$, was added diisopropylcarbodiimide (0.154gm, 1.223 $\mathrm{mmol}$ ) and was allowed to stir for 10 minutes. To this reaction mixture, dimethylaminopyridine (DMAP) $(0.031 \mathrm{gm}, 0.254 \mathrm{mmol})$, triethylamine $(0.0857 \mathrm{gm}$, $0.848 \mathrm{mmol}) 4 \mathrm{R} / 4 \mathrm{~S}(0.140 \mathrm{~g}, 0.848 \mathrm{mmol})$ in $\mathrm{CH}_{2} \mathrm{Cl}_{2}(1 \mathrm{ml})$ were added successively at $0^{\circ} \mathrm{C}$. The reaction mixture was stirred for 1 day at room temperature. The reaction mixture was filtered, diluted with dichloromethane $(50 \mathrm{ml})$ and washed by saturated $\mathrm{NaCl}$ $(20 \mathrm{ml})$. The organic layer was dried over anhydrous $\mathrm{MgSO}_{4}$ and evaporated under reduced pressure. The residue was purified by column chromatography on silica gel (eluted with $\mathrm{CHCl}_{3} / \mathrm{MeOH}(40: 1)$ ) to give 5R/5S (0.331gm, 77\%). 
5R: ${ }^{1} \mathrm{H}$ NMR $\left(300 \mathrm{MHz}, \mathrm{CDCl}_{3}\right) \delta=5.366-5.318(2 \mathrm{H}, \mathrm{m}) ; 4.569-4.534(1 \mathrm{H}, \mathrm{m})$; 4.262-4.098 (2H, m); 3.804-3.782 (3H, d, J = 11Hz); 2.363 (6H, overlapping protons); $1.647-1.619(2 \mathrm{H}, \mathrm{m}) ; 1.306(20 \mathrm{H}, \mathrm{s}) ; 0.880(3 \mathrm{H}, \mathrm{t}) . \mathrm{MS}(\mathrm{ESI}) \mathrm{m} / \mathrm{z} 453.4[\mathrm{M}+\mathrm{Na}]$.

5S: ${ }^{1} \mathrm{H}$ NMR (500MHz, $\left.\mathrm{CDCl}_{3}\right) \delta=5.366-5.318(2 \mathrm{H}, \mathrm{m}) ; 4.569-4.534(1 \mathrm{H}, \mathrm{m})$; 4.262-4.098 (2H, m); 3.804-3.782 (3H, d, J = 11Hz); 2.363 (6H, overlapping protons); 1.647-1.619 (2H, m); $1.166(20 \mathrm{H}, \mathrm{s}) ; 0.90(3 \mathrm{H}, \mathrm{t})$. MS (ESI) m/z $453.3[\mathrm{M}+\mathrm{Na}]$.

General procedure for the synthesis of $6 \mathrm{R}, 6 \mathrm{~S}, 7 \mathrm{R}, 7 \mathrm{~S}$ : To a solution of $5 \mathrm{R} / 5 \mathrm{~S}$ or $3 \mathrm{R} / 3 \mathrm{~S}$ (1Eq) in $\mathrm{CH}_{2} \mathrm{Cl}_{2}(1 \mathrm{ml})$ was added bromotrimethylsilane (TMSBr) $(2 \mathrm{Eq})$, and the reaction mixture was stirred for $1 \mathrm{~h}$ at room temperature. The reaction mixture was condensed under reduced pressure, and methanol was added to it. This was stirred again for $30 \mathrm{~min}$, Methanol form the reaction mixture was evaporated and the residue was purified by column chromatography on silica gel (eluted with $\mathrm{CHCl}_{3} / \mathrm{MeOH}(10: 1)$ ) to give $6 \mathrm{R} / 6 \mathrm{~S}$ or $7 \mathrm{R} / 7 \mathrm{~S}$ respectively, and were isolated as pure products and immediately converted to sodium salts due to poor stability.

Synthesis of R-3-CCPA/ S-3-CCPA: To a solution of $6 \mathrm{R} / 6 \mathrm{~S}(0.066 \mathrm{~g}, 0.159 \mathrm{mmol})$ in diethyl ether $(2 \mathrm{ml})$ was added $1 \mathrm{M} \mathrm{NaOH}(0.0063 \mathrm{~g})$ in water at $0^{\circ} \mathrm{C}$. The reaction mixture was allowed to stir at room temperature for 30 minutes and a white precipitate was observed. The diethyl ether was removed on vacuum and the sample was freeze dried to obtain pure compounds R-3-CCPA/S-3-CCPA in quantitative yields.

R-3-CCPA: Optical rotation $=+7.3^{\circ}$ (methanol); ${ }^{1} \mathrm{H}$ NMR $\left(500 \mathrm{MHz}, \mathrm{CD}_{3} \mathrm{OD}\right)$ $\delta=5.366-5.318(2 \mathrm{H}, \mathrm{m}) ; 4.2-4.0(1 \mathrm{H}, \mathrm{m}) ; 3.65-3.45(2 \mathrm{H}, \mathrm{m}) ; 2.2-2.0(4 \mathrm{H}$, overlapping protons); $1.98-1.619(4 \mathrm{H}, \mathrm{m}$, overlapping protons $) ; 1.4-1.2(20 \mathrm{H}, \mathrm{s}) ; 0.90(3 \mathrm{H}, \mathrm{t}) .{ }^{31} \mathrm{P}$ NMR (300MHz, $\mathrm{CD}_{3} \mathrm{OD}$, Phosphoric acid external standard) $\delta=44.110 ;$ MS (ESI) $\mathrm{m} / \mathrm{z}$ $415.6[\mathrm{M}-\mathrm{H}]$. HRMS calcd for $\mathrm{C}_{22} \mathrm{H}_{40} \mathrm{O}_{5} \mathrm{P} ; 415.2613$; found: 415.2612 .

S-3-CCPA: Optical rotation $=-7.9^{\circ}$ (methanol) ${ }^{1} \mathrm{H}$ NMR $\left(500 \mathrm{MHz}, \mathrm{CD}_{3} \mathrm{OD}\right)$ $\delta=5.366-5.318(2 \mathrm{H}, \mathrm{m}) ; 4.2-4.0(1 \mathrm{H}, \mathrm{m}) ; 3.65-3.45(2 \mathrm{H}, \mathrm{m}) ; 2.2-2.0(4 \mathrm{H}$, overlapping protons); 1.98-1.619 (4H, m, overlapping protons); 1.4-1.2 (20H,s); $0.90(3 \mathrm{H}, \mathrm{t})$. MS (ESI) $\mathrm{m} / \mathrm{z} 415.1$ [M-H]. HRMS calcd for $\mathrm{C}_{22} \mathrm{H}_{40} \mathrm{O}_{5} \mathrm{P} ; 415.2613$; found: 415.2623 .

Synthesis of $8 \mathrm{R} / 8 \mathrm{~S}$ : To a solution of $7 \mathrm{R} / 7 \mathrm{~S}(0.066 \mathrm{~g}, 0.159 \mathrm{mmol})$ in diethyl ether $(2 \mathrm{ml})$ was added $1 \mathrm{M} \mathrm{NaOH}(0.0063 \mathrm{~g})$ in water at $0^{\circ} \mathrm{C}$. The reaction mixture was allowed to stir at room temperature for 30 minutes and a white precipitate was observed. The diethyl ether was removed on vacuum and the sample was freeze dried to obtain pure compounds $8 \mathrm{R} / 8 \mathrm{~S}$ in quantitative yields.

8R: ${ }^{1} \mathrm{H}$ NMR (300MHz, CD3OD) $\delta=7.340(5 \mathrm{H}, \mathrm{m}) ; 4.579(2 \mathrm{H}, \mathrm{s}) ; 4.25(1 \mathrm{H}, \mathrm{p}) ; 3.55$ $(2 \mathrm{H}, \mathrm{m}) ; 2.3-1.5(4 \mathrm{H}, \mathrm{m}) .{ }^{31} \mathrm{P}$ NMR $\left(300 \mathrm{MHz}, \mathrm{CD}_{3} \mathrm{OD}\right.$, Phosphoric acid external standard) $\delta=43.535$; MS (ESI) m/z $240.9[\mathrm{M}-\mathrm{H}]$. HRMS calcd for $\mathrm{C}_{11} \mathrm{H}_{14} \mathrm{O}_{4} \mathrm{P}$; 241.0635; found: 241.0632 . 
8S: ${ }^{1} \mathrm{H}$ NMR (500MHz, CD $\left.{ }_{3} \mathrm{OD}\right) \delta=7.378-7.312(5 \mathrm{H}, \mathrm{m}) ; 4.61$ (2h, s); 4.419-4.408 (1H, p); 3.628-3.619 (2H, m); 2.325-1.733 (4H, m). MS (ESI) m/z 240.8 [M-H]; HRMS calcd for $\mathrm{C}_{11} \mathrm{H}_{14} \mathrm{O}_{4} \mathrm{P} ; 241.0635$; found: 241.0638 .

\section{Conclusion}

In conclusion, we have synthesized pure stereoisomers of 3-CCPA and found that they inhibited ATX in vitro and B16-F10 melanoma metastasis in vivo without significant stereochemical preference. The lack of stereoselectivity is underlined by the equal efficacy of the racemic mixture. Interestingly, at the LPA ${ }_{5}$ GPCR the S-stereoisomer (S-3-CCPA) showed significantly higher efficacy. This is the first indication that the $\mathrm{LPA}_{5}$ receptor, unlike the $\mathrm{LPA}_{1,2,3}$ receptors shows stereo-selective activation by CCPA ligands. 


\section{Chapter 3. Benzyl and Naphthalene-Methyl Phosphonic Acid Inhibitors of Autotaxin with Anti-Invasive and Anti-Metastatic Actions*}

Autotaxin (ATX, NPP2) is member of the nucleotide pyrophosphate phosphodiesterase (NPP) enzyme family. ATX catalyzes the hydrolysis of lysophosphatidylcholine (LPC) via a lysophospholipase D (LPLD) activity that leads to the generation of the growth factor-like, lipid mediator lysophosphatidic acid (LPA). ${ }^{16,17}$ ATX is a $125 \mathrm{kDa}$ glycoprotein, originally isolated from human melanoma cells, that stimulates tumor cell motility and has been implicated in the metastatic and invasive properties, as well as chemotherapeutic resistance of many carcinomas. ${ }^{56,132-138,140,152}$ NPP6 and NPP7 are the only other known NPP isoforms that utilize lysophospholipids as substrates. However, In contrast to ATX, NPP6 and NPP7 act as lysophospholipase C. NPP6 cleaves phosphocholine from LPC, sphingosylphosphorylcholine and glycerophosphorylcholine to generate monoacylglycerol, sphingosine and glycerol, respectively. ${ }^{153}$ NPP7, also referred to as alkaline sphingomyelinase hydrolyzes sphingomyelin to generate ceramide in the intestinal tract but also cleaves phosphocholine from LPC and platelet activating factor to generate monoacyl and alkyl-acetyl glycerols. ${ }^{154,155}$

ATX is required for normal development. Homozygous ATX knockout mice die in utero at day 9.5 coinciding with a period of vascular stabilization. ${ }^{156,157}$ Likewise, ATX plays an important role in the development of the nervous system as ATX knockout mice show defects in neural tube development. ${ }^{158}$ LPA is a mitogen, motogen, and anti-apoptotic agent, which provides survival advantages to carcinomas that utilize LPA in an autocrine or paracrine fashion. Ovarian cancer cells produce high levels of LPA. ${ }^{3,159,160}$ Copy numbers increase in ovarian cancers in chromosomal region 8q24, which contains the genes encoding for ATX and the Myc oncogene. ${ }^{161}$ Euer et.al. found that ATX was among the 40 most upregulated genes in highly metastatic cancers. ${ }^{162}$ Recently it has been shown that ectopic expression of ATX in mice leads to mammary intraepithelial neoplasia, which develops into invasive and metastatic tumors. ${ }^{163}$ ATX inhibits paclitaxel-induced apoptosis in breast cancer cells, ${ }^{140}$ and LPA renders ovarian cancer cells chemoresistant to cisplatin and adriamycin. ${ }^{65}$ ATX is also overexpressed in patients with recurrent disease after prior treatment with chemotherapy. ${ }^{164}$ In a genome-wide siRNA screen, we identified ATX as a candidate drug-resistance gene in ovarian cancer. ${ }^{135}$ In addition we showed that a lipid-like, small-molecule inhibitor of ATX, carba-cyclic-phosphatidic acid increases the sensitivity of resistant ovarian cancer cells to paclitaxel treatment. ${ }^{135}$

* This chapter is adapted with permission from Wiley-VCH Verlag GmbH \& Co. KGaA. Gupte, R.; Patil, R.; Liu, J.; Wang, Y.; Lee, S. C.; Fujiwara, Y.; Fells, J.; Bolen, A. L.; Emmons-Thompson, K.; Yates, C. R.; Siddam, A.; Panupinthu, N.; Pham, T. C.; Baker, D. L.; Parrill, A. L.; Mills, G. B.; Tigyi, G.; Miller, D. D. Benzyl and naphthalene methylphosphonic acid inhibitors of autotaxin with anti-invasive and anti-metastatic activity. ChemMedChem. 2011, 6, 922-935. 
The ATX-LPA-LPA receptor axis is a promising therapeutic target for the management of cancer metastasis and therapeutic resistance. ATX shows feedback inhibition by its hydrolysis products LPA, CPA, and sphingosine-1-phosphate (S1P). ${ }^{18,19}$ Thus, many initially identified ATX inhibitors are lipid-like substrate or product analogs. ${ }^{9,165-171}$ The characteristics of this type of compounds limit their utility as potential lead compounds for drug development. Non-lipid ATX inhibitors have also been identified but most of these compounds lack sufficient potency and characterization in tumor models. ${ }^{1,167,172-176}$ Recently, Ferry and colleagues described a non-lipid ATX inhibitor 4-tetradecanoylaminobenzyl phosphonic acid (S32826, Figure 3.1) that possessed nanomolar activity in vitro. ${ }^{177}$ Unfortunately, S32826 failed to show activity in cellular and in vivo systems. We hypothesized that hydrolysis of the amide bond present in S32826 could be the reason for its instability and thus lack of activity in cellular systems.

To overcome the presumed lack of stability of S32826, we designed analogs that were expected to be more stable than the parent compound. We have generated a panel of analogs that inhibit ATX with potencies comparable to that of S32826. These stabilized analogs inhibit ATX via a mixed-mode mechanism in vitro without any effect on the related lysophospholipid phosphodiesterases, NPP6 and NPP7 or on LPA receptors (LPAR). Two of these compounds, 30 and $38 \mathrm{~b}$ inhibited ATX-dependent invasion of rat MM1 hepatoma cells of mesothelial cell and human umbilical cord vascular endothelialcell (HUVEC) monolayers in vitro. In addition, 30 and $38 \mathrm{~b}$ showed a profound reduction in lung foci in vivo using the B16-F10 syngeneic melanoma metastasis model in $\mathrm{C} 57 \mathrm{BL} / 6$ mice. Based on these results compounds 30 and $38 \mathrm{~b}$ represent promising leads for further synthetic improvement and also provide proof of principle that ATX inhibitors offer therapeutic utility in the control of cancer metastasis in vivo.

\section{Chemical Synthesis}

The synthesis 4-(hexadecane-1-sulfonylamino)benzyl phosphonic acid (12) is depicted in Scheme 3.1. Commercially available 1-hexadecanesulfonyl chloride (10) was added to a mixture of 4-aminobenzylphosphonic acid diethyl ester (9) and

$\mathrm{N}, \mathrm{N}$-diisopropylethylamine in THF under reflux conditions to give compound 11, which was deprotected with bromotrimethylsilane (TMSBr) followed by addition of $\mathrm{MeOH}$ under stirring for $30 \mathrm{~min}$ to afford compound 12. The synthesis of compound 18 started with alkylation of 4-hydroxymethylphenol (13) (Scheme 3.2) using 1-bromotetradecane (14) in the presence of $\mathrm{K}_{2} \mathrm{CO}_{3}$ and 18-crown-6 to get compound 15 followed by treatment

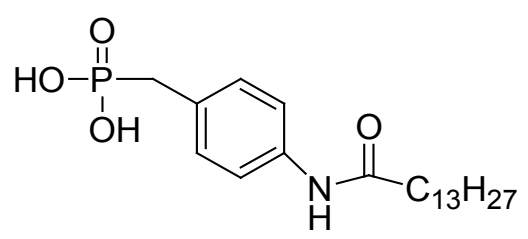

Figure 3.1. ATX Inhibitor S32826. 


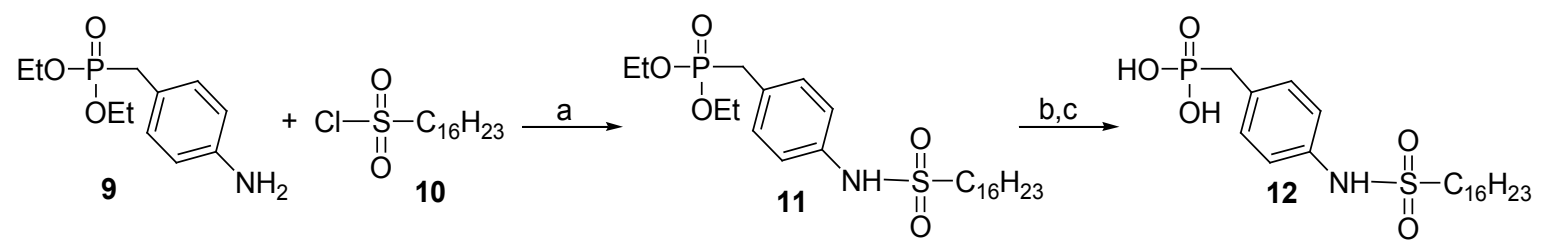

Scheme 3.1. Synthesis of Compound 12.

Reagents and conditions: (a) N,N-diisopropylethylamine,THF, reflux, 24h; (b) TMSBr, $\mathrm{CH}_{3} \mathrm{CN}$, Reflux, 1h; (c) $\mathrm{MeOH}, 30 \mathrm{~min}, \mathrm{rt}$.
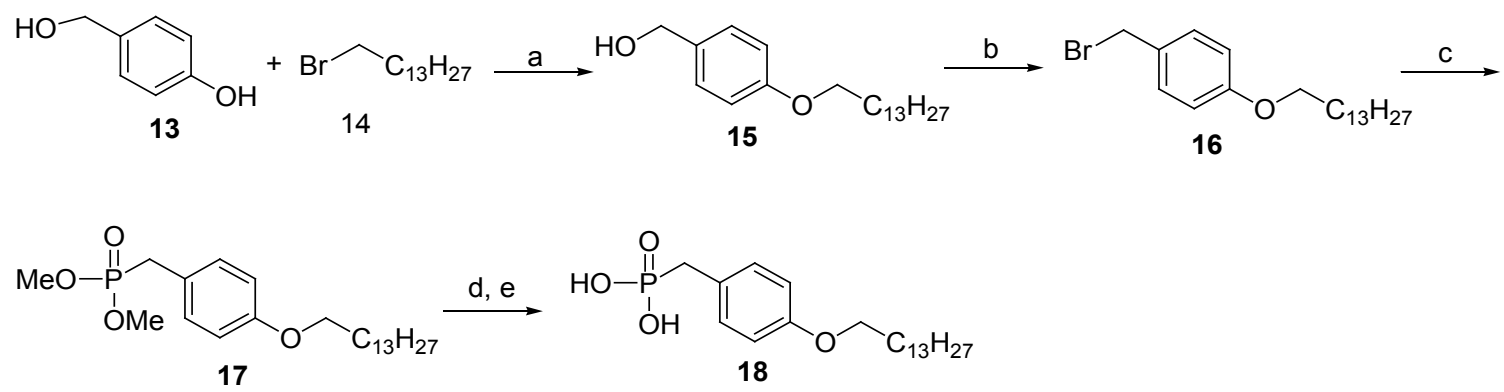

\section{Scheme 3.2. Synthesis of Compound 18.}

Reagents and conditions: (a) $\mathrm{K}_{2} \mathrm{CO}_{3}$, 18-crown-6, acetone, reflux, 16h; (b) $\mathrm{PBr}_{3}$, ether, rt, 30min; (c) $\mathrm{P}(\mathrm{OMe})_{3}$, reflux, 18h; (d) TMSBr, $\mathrm{CH}_{3} \mathrm{CN}$, Reflux, 1h; (e) $\mathrm{MeOH}, 30 \mathrm{~min}$, rt. 
with $\mathrm{PBr}_{3}$ to obtain 16 in $98 \%$ yield. The Michealis-Arubuzov reaction ${ }^{178}$ on compound 16 in trimethyl phosphate provided compound 17, which was then deprotected using TMSBr in anhydrous acetonitrile to yield 18 .

Scheme 3.3 demonstrates the synthesis of $(E)$-4-(pentadec-1-enyl)benzylphosphonic acid (26) and 4-pentadecylbenzylphosphonic acid (30). (E)-Methyl 4-(pentadec-1-enyl) benzoate (21) was synthesized by the Heck coupling of 19 and 20 using Palladium (II) acetate, and triethyl amine in anhydrous DMF. Compound 21 was reduced using LAH in $\mathrm{THF}$ at $0^{\circ} \mathrm{C}$ to room temperature to produce 22 and also saturated under catalytic hydrogenation conditions to generate compound 23. Bromination of Compound 22 with $\mathrm{PBr}_{3}$ in ether gave 24 which was then subjected to the Michealis-Arubuzov reaction ${ }^{178}$ using trimethyl phosphite to get 25. Compound 25 was treated with $\mathrm{TMSBr}$ in acetonitrile followed by addition of $\mathrm{MeOH}$ to furnish 26. Compound 30 was synthesized utilizing the same approach starting from compound 23. The synthesis of 6-substituted naphthalen-2-yl-methyl phosphonic acid analogs (38a-b \& 42a-b) was synthesized using the same procedure described for the synthesis of compounds 34 and 30 (Scheme 3.4). We then focused our medicinal chemistry efforts on phosphomimetic functional groups, the phosphomimetics include compounds 45, 49, 50, and 51 (Scheme 3.5). We started with the conversion of compound 27 into an aldehyde derivative 43 using pyridinium dichromate (PDC) in $\mathrm{CH}_{2} \mathrm{Cl}_{2}$. The resulting aldehyde 43 was then converted to the $\alpha$-hydroxy phosphonate derivative 36 using the Pudovik reaction. ${ }^{169,179}$ Compound 44 was deprotected using TMSBr to produce target compound 45. Compound 44 was treated with DAST in ether, $\mathrm{SOCl}_{2} / \mathrm{CH}_{2} \mathrm{Cl}_{2}$ and $\mathrm{PBr}_{3}$ /ether to obtain the desired compounds 46 , 47, and 48, respectively. Finally, the compounds 46, 47, and 48 were treated with TMSBr followed by addition of $\mathrm{MeOH}$ to afford compounds 49, 50, and 51 in good yields.

The synthesis of target compounds 53 and 55 is outlined in Scheme 3.6. Compound 27 was treated with a mixture of $1 H$-tetrazole and bis(2-cyanoethyl) $N, N$-diisopropylphosphoramidite in anhydrous $\mathrm{CH}_{2} \mathrm{Cl}_{2}$ followed by the addition of hydrogen peroxide to give the bis-cyanoethylprotected fatty alcohol phosphate 52 . Removal of the cyano ethyl groups with treatment of methanolic $\mathrm{KOH}$ followed by acidification furnished the phosphate 53. Similarly 27 was treated with a mixture of $1 H$-tetrazole and bis(2-cyanoethyl) $N, N$-diisopropylphosphoramidite in anhydrous $\mathrm{CH}_{2} \mathrm{Cl}_{2}$ followed by reflux in the presence of elemental sulfur to give bis-cyanoethyl protected fatty alcohol thiophosphate 38 , which, in turn, was treated with methanolic $\mathrm{KOH}$ followed by acidification to yield the thiophosphate 55 .

\section{Biological Results}

Effect of 4-Substituted Benzyl Phosphonic Acid and 6-Substituted Naphthalene-2ylMethyl Phosphonic Acid Derivatives on Autotaxin and LPAR

The first level of testing was done using $10 \mu \mathrm{M}$ concentrations of the compounds added to $2 \mathrm{nM}$ recombinant human ATX and the FRET substrate FS-3. After a $2 \mathrm{~h}$ incubation 

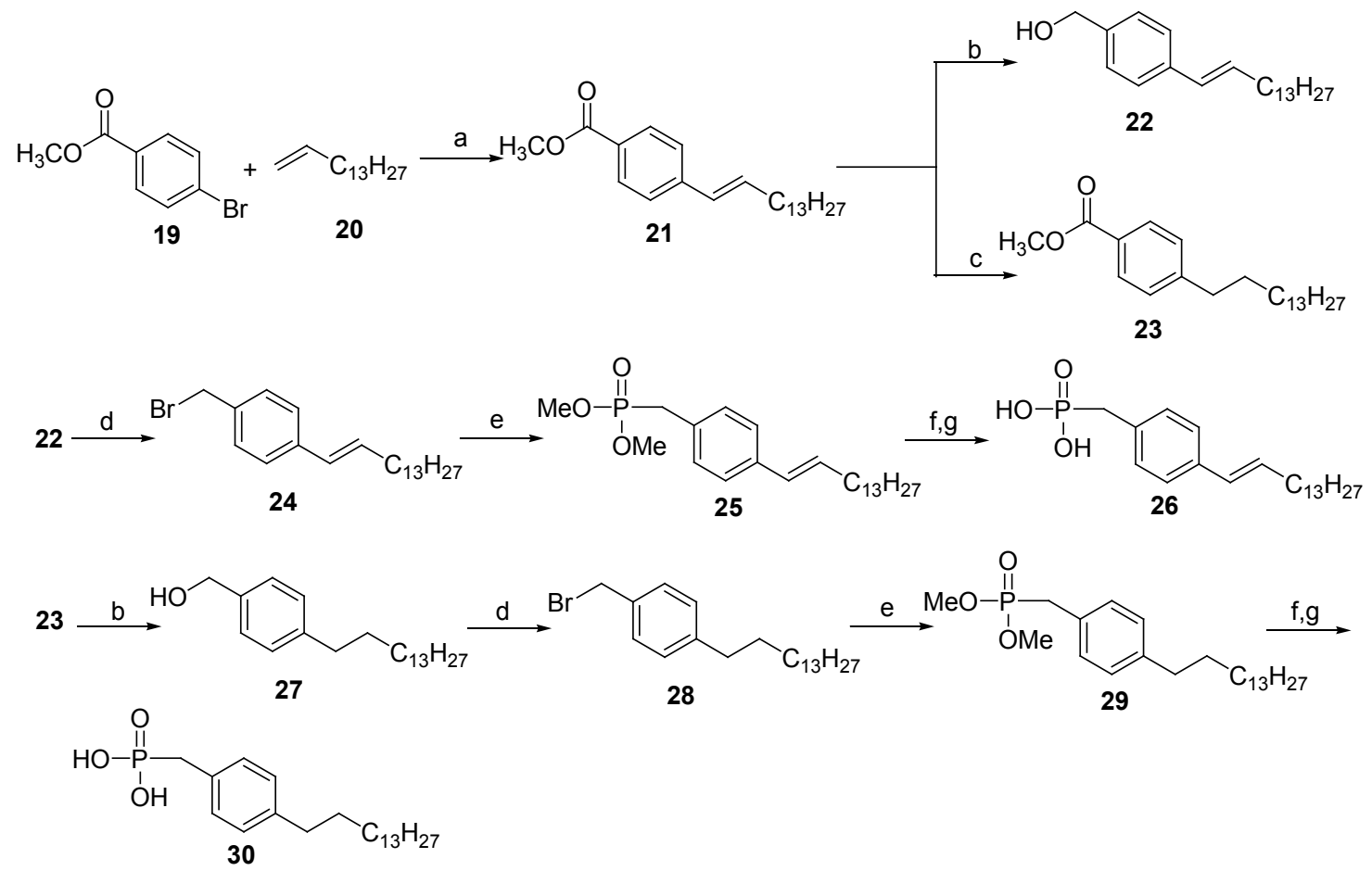

Scheme 3.3. Synthesis of Compounds 23 and 30.

Reagents and conditions: (a) $\mathrm{Pd}(\mathrm{OAc})_{2}, \mathrm{Et}_{3} \mathrm{~N}, \mathrm{DMF}$, reflux, $16 \mathrm{~h}$; (b) LAH, THF, $0^{\circ} \mathrm{C}-\mathrm{rt}$, 4h; (c) $\mathrm{H}_{2} / \mathrm{Pd} / \mathrm{C}, \mathrm{MeOH}$; (d) $\mathrm{PBr}_{3}$, ether, rt, 30min; (e) $\mathrm{P}(\mathrm{OMe})_{3}$, reflux, 18h; (f) $\mathrm{TMSBr}$, CH3CN, Reflux,1h; (g) MeOH, 30min, rt. 

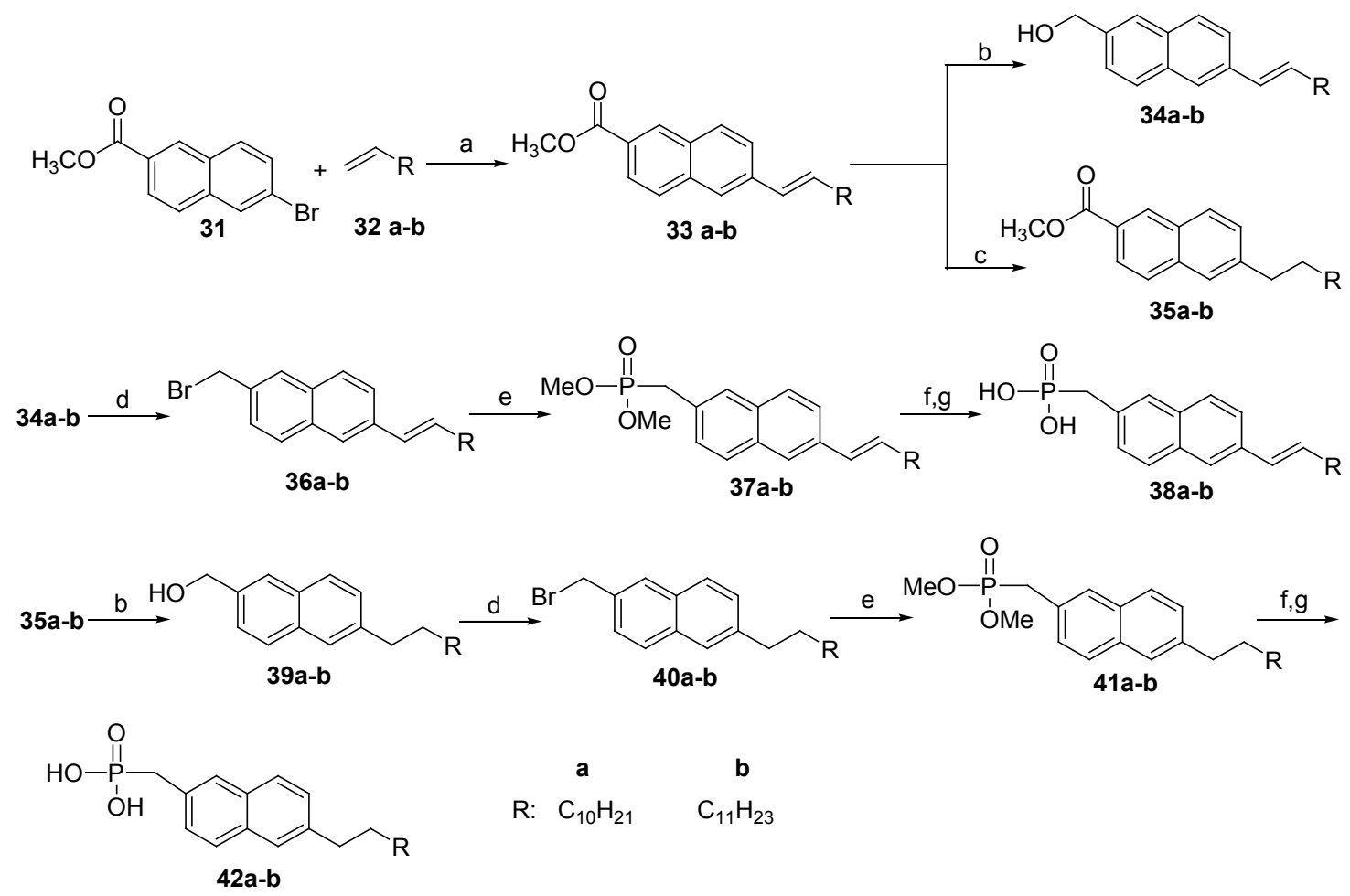

Scheme 3.4. Synthesis of Compounds 38a-b and 42a-b.

Reagents and conditions: (a) $\mathrm{Pd}(\mathrm{OAc})_{2}, \mathrm{Et}_{3} \mathrm{~N}$, DMF, reflux, 16h; (b) LAH, THF, $0^{\circ} \mathrm{C}$-rt, 4h; (c) $\mathrm{H}_{2} / \mathrm{Pd} / \mathrm{C}, \mathrm{MeOH}$; (d) $\mathrm{PBr}_{3}$, ether, rt, 30min; (e) $\mathrm{P}(\mathrm{OMe})_{3}$, reflux, 18h; (f) $\mathrm{TMSBr}$, $\mathrm{CH}_{3} \mathrm{CN}$, Reflux, 1h; (g) $\mathrm{MeOH}, 30 \mathrm{~min}$, rt. 


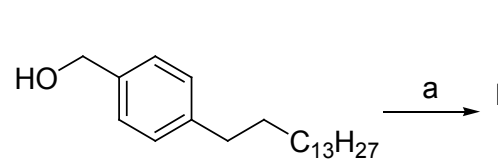

27

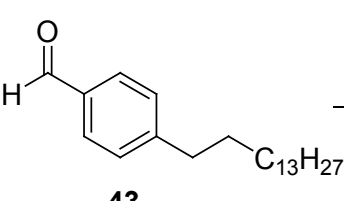

43

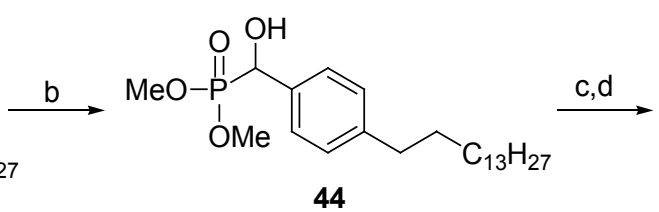

44<smiles>CCCCCCCCc1ccc(C(O)P(=O)(O)O)cc1</smiles>

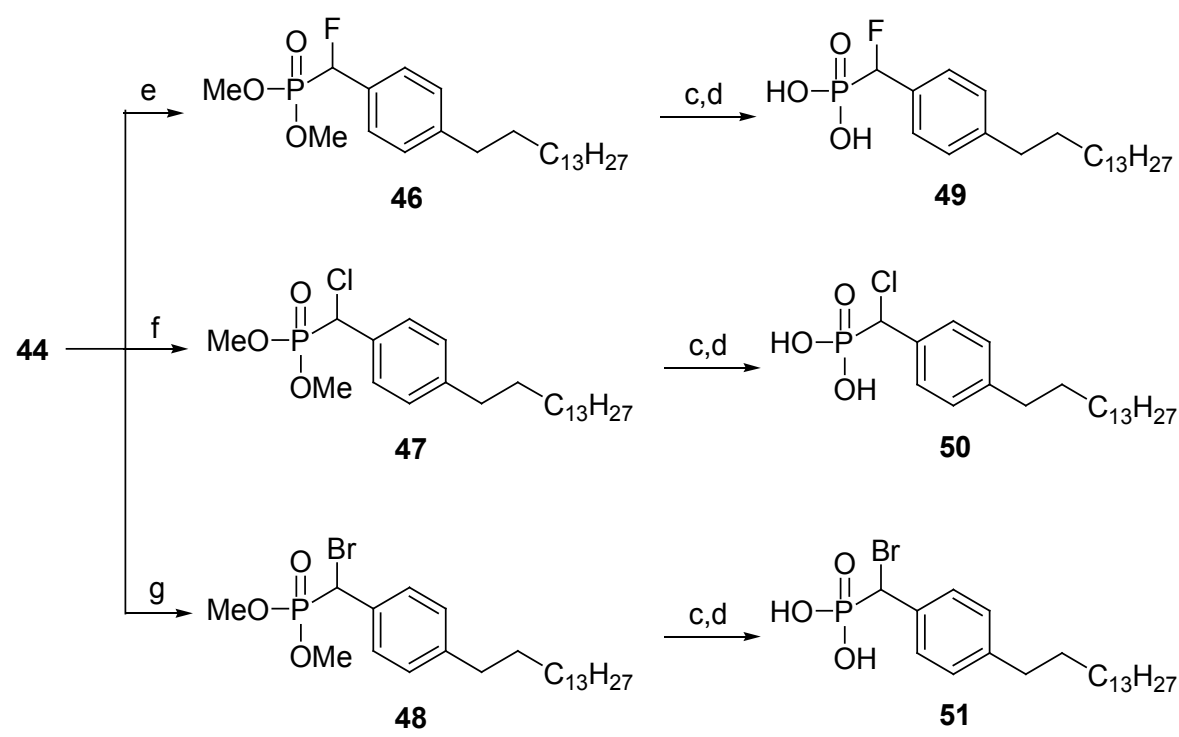

Scheme 3.5. Synthesis of Compounds 45, 49, 50 and 51.

Reagents and conditions: (a) PDC, DCM, rt, 16h; (b) $\mathrm{HP}\left(\mathrm{OCH}_{3}\right)_{2}, \mathrm{Et}_{3} \mathrm{~N}, 0^{\circ} \mathrm{C}$-rt, 4h; (c) $\mathrm{TMSBr}, \mathrm{CH}_{3} \mathrm{CN}$, Reflux, 1h; (d) $\mathrm{MeOH}, 30 \mathrm{~min}$, rt; (e) DAST, ether, $0^{\circ} \mathrm{C}-\mathrm{rt}, 1 \mathrm{~h}$; (f) $\mathrm{SOCl}_{2}$, DCM, reflux, 1h; (g) $\mathrm{PBr}_{3}$, ether, rt, 30min. 


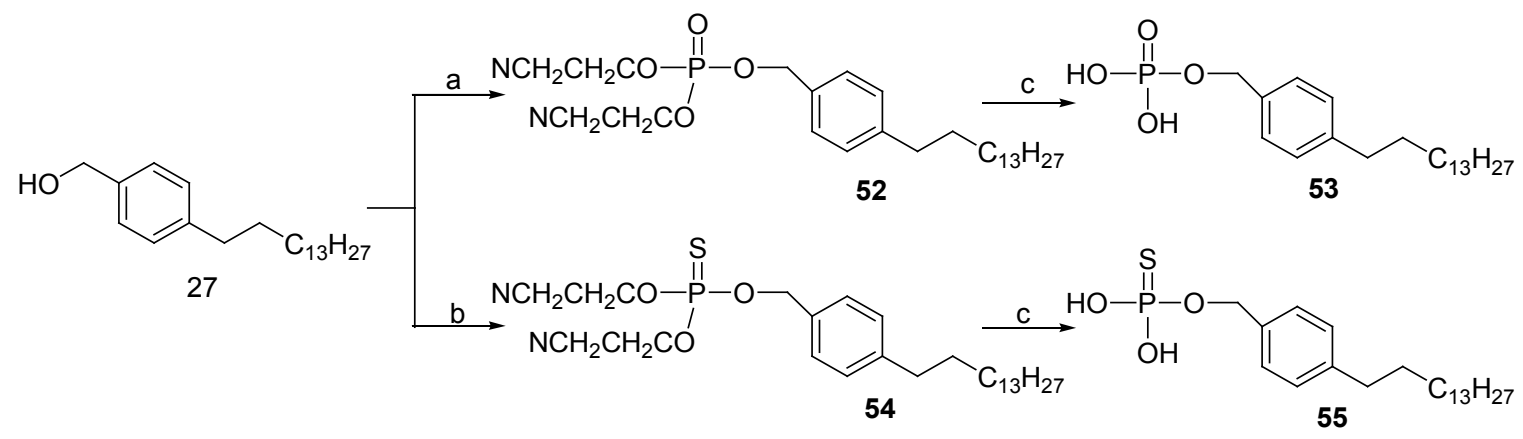

Scheme 3.6. Synthesis of Compounds 53 and 55.

Reagents and conditions: (a)(i) bis(2-cyanoethyl)-N,N-diisopropylphosphoramidite, 1H-tetrazole, $\mathrm{CH}_{2} \mathrm{Cl}_{2}$, rt; (ii) $50 \% \mathrm{H} 2 \mathrm{O} 2$; (b)(i) bis(2-cyanoethyl)-

$\mathrm{N}, \mathrm{N}$-diisopropylphosphoramidite, $1 \mathrm{H}$-tetrazole, $\mathrm{CH}_{2} \mathrm{Cl}_{2}$, rt; (ii) sulfur, reflux, 2h; (c)(i) $\mathrm{KOH}, \mathrm{MeOH}$; (ii) dil $\mathrm{HCl}$.

the amount of FS-3 hydrolyzed was measured and the residual ATX activity was expressed as a percent of the vehicle-treated sample less the autolysis of FS-3 in the absence of ATX. In this assay, S32826 reduced the amount of FS-3 hydrolyzed by $97 \%$ (Table 3.1 and Table 3.2). Among the 4-substituted benzyl phosphonic acid analogs compound 30 showed 95\% inhibition of FS-3 hydrolysis (Table 3.1), whereas compound $38 \mathrm{~b}$ from the 6-substituted naphthalene-2yl-methyl phosphonic acid series reduced FS-3 hydrolysis by 83\% (Table 3.2). Dose-response curves were generated with compounds S32836, 30 and 38b and compared to the feedback inhibition of the ATX product LPA (Figure 3.2). Each of these three compounds dose-dependently and completely inhibited ATX. The ATX inhibition assays were carried out in Dr.Tigyi's laboratory.

Subsequently, we generated analogs of compounds 22 and $38 \mathrm{~b}$ and examined their inhibition of ATX. The modifications were either in the aliphatic chain, the linker of the phosphate moiety, or on the phosphate moiety itself (Table 3.1 and Table 3.2). The most effective analogs based on the single $10-\mu \mathrm{M}$ dose inhibition assay were extensively characterized to determine $\mathrm{IC}_{50}, \mathrm{~K}_{\mathrm{i}}$, and $\mathrm{K}_{\mathrm{i}}$ ' values against ATX-mediated hydrolysis of FS-3. Replacement of the amide with a sulfonamide (12) reduced potency. Introduction of an ether (18) or alkene (26) connecting the hydrocarbon chain to the benzyl ring decreased the potency compared to the simple aliphatic chain. Linkage of the phosphate moiety in compound 53 through a methyl phosphonate reduced efficacy.

However, converting the phosphate to a thiophosphate (55) in this scaffold increased efficacy at $10 \mu \mathrm{M}$ 5.6-fold. $\alpha$-Halogenation of the linker methyl group generally decreased potency of compounds 49,50 , and 51 relative to compound 30 . Insertion of a $\alpha$-hydroxyl group into the linker methylene increased the potency of this analog but it did not surpass that of compound 30 . 
Table 3.1. Characterization of Benzyl Phosphonic Acids at ATX, NPP6 and NPP7.

\begin{tabular}{|c|c|c|c|c|c|c|c|c|c|c|}
\hline Compound & $\mathbf{X}$ & $\mathbf{Y}$ & $\mathbf{R}$ & $\begin{array}{l}\text { ATX } \\
\text { Activity, } \\
\text { \% Control } \\
(10 \mu M)\end{array}$ & $\begin{array}{l}\text { ATX } \\
\text { IC }_{50} \\
(\mu \mathrm{M})\end{array}$ & $\begin{array}{l}\text { ATX } \\
\text { Mechanism } \\
\text { of } \\
\text { Inhibition }\end{array}$ & $\begin{array}{l}\text { ATX } \\
K_{\mathbf{i}}(\mu M)\end{array}$ & $\begin{array}{l}\text { ATX } \\
\mathbf{K}_{\mathbf{i}}^{\prime}(\mu \mathrm{M})\end{array}$ & $\begin{array}{l}\text { NPP6 } \\
\text { Activity, } \\
\text { \% Control } \\
(10 \mu M)\end{array}$ & $\begin{array}{l}\text { NPP7 } \\
\text { Activity, } \\
\text { \% Control } \\
(10 \mu M)\end{array}$ \\
\hline S32826 & $\mathrm{O}$ & $\mathrm{CH}_{2}$ & $\mathrm{HN}_{\mathrm{C}_{13} \mathrm{H}_{27}}$ & 2.6 & ND & ND & $\mathrm{N} / \mathrm{A}$ & $\mathrm{N} / \mathrm{A}$ & 102.1 & 101.2 \\
\hline 12 & $\mathrm{O}$ & $\mathrm{CH}_{2}$ & $\mathrm{HN}^{-} \stackrel{\mathrm{O}}{\mathrm{O}} \mathrm{O}^{\mathrm{O}} \mathrm{C}_{16} \mathrm{H}_{33}$ & 24.1 & ND & ND & N/A & N/A & 102.0 & 93.5 \\
\hline 18 & $\mathrm{O}$ & $\mathrm{CH}_{2}$ & $\widehat{\mathrm{O}} \mathrm{C}_{13} \mathrm{H}_{27}$ & 30.4 & ND & ND & $\mathrm{N} / \mathrm{A}$ & $\mathrm{N} / \mathrm{A}$ & 102.0 & 100.6 \\
\hline 26 & $\mathrm{O}$ & $\mathrm{CH}_{2}$ & $\mathrm{C}_{13} \mathrm{H}_{27}$ & 18.8 & ND & ND & N/A & N/A & 104.0 & 97.7 \\
\hline 30 & $\mathrm{O}$ & $\mathrm{CH}_{2}$ & $\mathrm{C}_{13} \mathrm{H}_{27}$ & 5.2 & 0.17 & Mixed & 0.27 & 0.28 & 96.5 & 96.7 \\
\hline 45 & $\mathrm{O}$ & $\mathrm{CHOH}$ & $\mathrm{C}_{13} \mathrm{H}_{27}$ & 9.2 & 0.73 & Mixed & 0.45 & 0.70 & 99.6 & 101.0 \\
\hline 49 & $\mathrm{O}$ & $\mathrm{CHF}$ & $\mathrm{C}_{13} \mathrm{H}_{27}$ & 42.3 & 17.9 & Mixed & 4.97 & 5.54 & 101.1 & 102.6 \\
\hline 50 & $\mathrm{O}$ & $\mathrm{CHCl}$ & $\mathrm{C}_{13} \mathrm{H}_{27}$ & 117.9 & ND & ND & $\mathrm{N} / \mathrm{A}$ & $\mathrm{N} / \mathrm{A}$ & 100.6 & 99.9 \\
\hline 51 & $\mathrm{O}$ & $\mathrm{CHBr}$ & $\mathrm{C}_{13} \mathrm{H}_{27}$ & 60.1 & 10.1 & Mixed & 6.10 & 2.97 & 99.3 & 99.5 \\
\hline 53 & $\mathrm{O}$ & $\mathrm{O}-\mathrm{CH}_{2}$ & $\mathrm{C}_{13} \mathrm{H}_{27}$ & 85.2 & ND & ND & N/A & N/A & 100.9 & 98.8 \\
\hline 55 & $\mathrm{~S}$ & $\mathrm{O}-\mathrm{CH}_{2}$ & $\mathrm{C}_{13} \mathrm{H}_{27}$ & 15.2 & 1.54 & Mixed & 4.45 & 4.43 & 98.8 & 92.9 \\
\hline
\end{tabular}

ND - not determined, NA - not applicable since the mechanism of inhibition was not determined. 
Table 3.2. Characterization of Naphthylphosphonic Acids at ATX, NPP6 and NPP7.

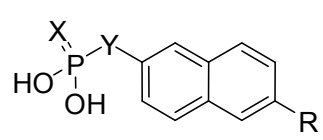

\begin{tabular}{|c|c|c|c|c|c|c|c|c|c|c|}
\hline Compound & $\mathbf{X}$ & $\mathbf{Y}$ & $\mathbf{R}$ & $\begin{array}{l}\text { ATX } \\
\text { Activity, } \\
\% \text { Control } \\
(10 \mu M)\end{array}$ & $\begin{array}{l}\text { ATX } \\
\text { IC } \\
(\mu \mathrm{M})\end{array}$ & $\begin{array}{l}\text { ATX } \\
\text { Mechanism } \\
\text { of Inhibition }\end{array}$ & $\begin{array}{l}\text { ATX } \\
\mathbf{K}_{\mathbf{i}}(\boldsymbol{\mu} M)\end{array}$ & $\begin{array}{l}\text { ATX } \\
K_{\mathbf{i}^{\prime}}(\mu M)\end{array}$ & $\begin{array}{l}\text { NPP6 } \\
\text { Activity, } \\
\text { \% Control } \\
(10 \mu M)\end{array}$ & $\begin{array}{l}\text { NPP7 } \\
\text { Activity, } \\
\text { \% Contro } \\
(\mathbf{1 0 \mu M})\end{array}$ \\
\hline 38a & $\mathrm{O}$ & $\mathrm{CH}_{2}$ & $\widehat{C}_{\mathrm{C}_{10} \mathrm{H}_{21}}$ & 61.3 & ND & ND & N/A & $\mathrm{N} / \mathrm{A}$ & 103.1 & 100.0 \\
\hline $38 \mathrm{~b}$ & $\mathrm{O}$ & $\mathrm{CH}_{2}$ & $\widehat{C}_{C_{11} H_{23}}$ & 17.3 & 1.40 & MIXED & 1.50 & 1.01 & 104.1 & 96.5 \\
\hline $42 a$ & $\mathrm{O}$ & $\mathrm{CH}_{2}$ & $\mathrm{C}_{10} \mathrm{H}_{21}$ & 19.9 & ND & ND & N/A & N/A & 101.0 & 98.8 \\
\hline $42 b$ & $\mathrm{O}$ & $\mathrm{CH}_{2}$ & $\mathrm{C}_{11} \mathrm{H}_{23}$ & 50.8 & ND & ND & N/A & N/A & 100.0 & 94.7 \\
\hline
\end{tabular}

ND - not determined, NA - not applicable since the mechanism of inhibition was not determined. 


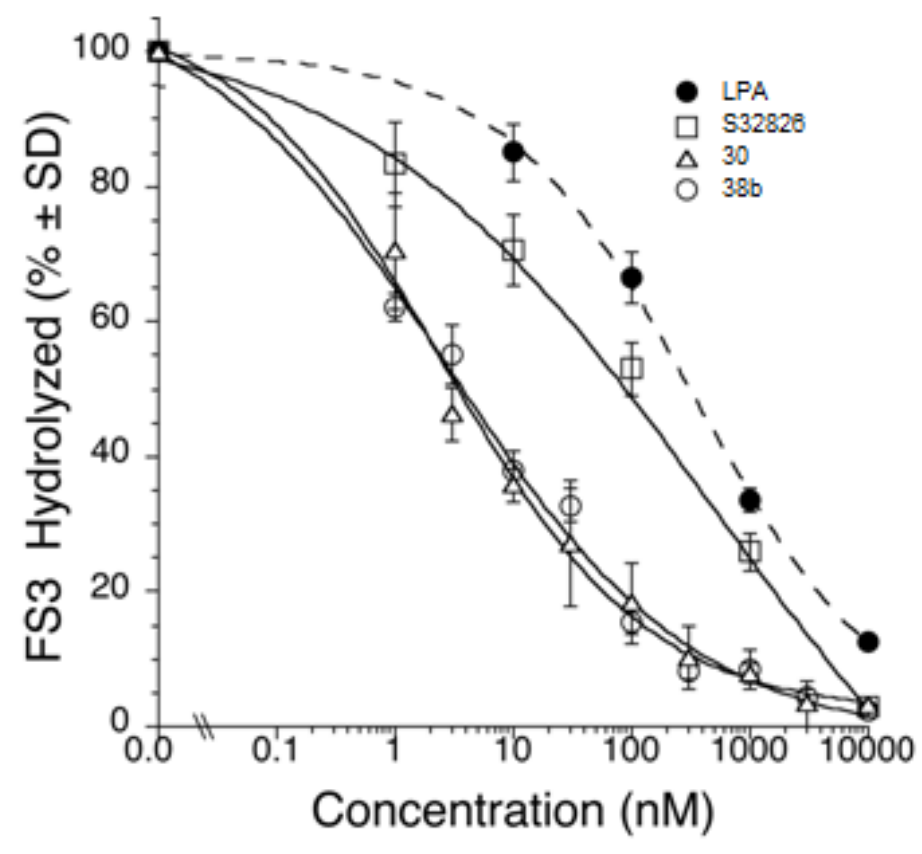

Figure 3.2. Inhibition of ATX-Mediated Hydrolysis of FS3 by LPA, S32826, Compound 30, or 38b.

$\operatorname{ATX}(2 \mathrm{nM})$ and $1 \mu \mathrm{M}$ FS3 were incubated in the presence of increasing concentrations of the inhibitors for $2 \mathrm{~h}$ and the fluorescent product was measured and expressed as percent of FS3 hydrolysis by ATX in the presence of vehicle less the autolysis of FS3 $(\mathrm{n}=3 \pm \mathrm{SD})$. 
Modification of the side chain at position 6 of the naphthalene-2yl-methyl phosphonic acid scaffold showed that the 10-carbon side chain was more effective than the 11 carbon chain and that incorporation of an alkene had differential effects depending on the chain length (decreased efficacy of compound 38a relative to $42 \mathrm{a}$, but increased efficacy of $38 \mathrm{~b}$ over $42 \mathrm{~b}$ ). Analysis of the seven analogs showed that compound 30 in the benzyl phosphonic acid series and compound $38 \mathrm{~b}$ in the naphthalene-methyl phosphonic acids were the most potent analogs with respect to ATX inhibition.

In order to determine the mechanism of ATX inhibition, $\mathrm{K}_{\mathrm{i}}$ (affinity of the compound for free enzyme) and $\mathrm{K}_{\mathrm{i}}$ ' (affinity of the compound for the enzyme substrate complex) were determined using simultaneous nonlinear fits of the Michaelis-Menten equations for competitive, uncompetitive, mixed-mode, and non-competitive inhibition as we have previously described. ${ }^{172,175,180}$ These experiments uniformly showed that these compounds displayed similar $\mathrm{K}_{\mathrm{i}}$ and $\mathrm{K}_{\mathrm{i}}{ }^{\prime}$ values which is consistent with a mixedworkmode type mechanism of inhibition.NPP6 and NPP7 are the only NPP isoforms beyond ATX that are known to utilize lysophospholipid phosphodiesters as substrates. Thus, specificity was addressed by determining the activity of NPP6 and NPP7 in the presence and absence of these analogs. None of the analogs tested blocked the activity of NPP6 or NPP7 by greater than $10 \%$ at a single $10 \mu \mathrm{M}$ dose (Table 3.1 and Table 3.2). The mechanism of inhibition of the comounds and their effect on NPP6 and NPP7 were carried out by Dr. Bakers group at the University of Memphis.

Some inhibitors of ATX, including LPA phosphonates ${ }^{165}$ and LPA bromophosphonates, ${ }^{170}$ have been shown to inhibit ATX and block LPA receptor subtypes. LPA bromophosphonate (LPA-BP) was also shown to inhibit cancer metastasis and reduced tumor size in mice. ${ }^{170}$ For this reason, we examined whether the two leads 30 and $38 \mathrm{~b}$ affected the activation of multiple LPA GPCR targets using cell lines overexpressing individual LPA GPCR coupled to $\mathrm{Ca}^{2+}$ mobilization as we have previously described. ${ }^{170}$ Analyses were done using $10 \mu \mathrm{M}$ concentrations of the test compounds alone or in combination with an $\mathrm{EC}_{50}$ concentration of LPA for the given receptor subtype to determine agonist and antagonist activity, respectively (Table 3.2).

Some of the compounds that showed $>10 \%$ attenuation of the LPA response or activation $>10 \%$ of LPA at a given receptor subtype at $10 \mu \mathrm{M}$ were subjected to doseresponse/inhibition experiments (Table 3.3). Unexpectedly, compounds 53 and 55 were weak but full agonists at $\mathrm{LPA}_{5}$ with $\mathrm{EC}_{50}$ values of $7.9 \mu \mathrm{M}$ and $2.9 \mu \mathrm{M}$, respectively. Compound 55 was also a partial agonist at $\mathrm{LPA}_{3}\left(\operatorname{Emax}_{10 \mu \mathrm{M}} \sim 44 \%\right.$ of the maximal LPA response). Compound 53 caused a 50\% reduction in the $\mathrm{LPA}_{2}$ response when applied at $10 \mu \mathrm{M}$. Compound $41 \mathrm{~b}$ elicited a $33 \%$ activation of $\mathrm{LPA}_{3}$ and a $17 \%$ activation at $\mathrm{LPA}_{5}$ when applied at $10 \mu \mathrm{M}$. Likewise, compound $30(10 \mu \mathrm{M})$ was a weak partial agonist at $\mathrm{LPA}_{2}\left(\mathrm{Emax}_{10 \mu \mathrm{M}} \sim 20 \%\right)$ whereas, analogs 45 and 49 inhibited this receptor subtype by $28 \%$ and $26 \%$, respectively. Based on these findings we conclude that these analogs were poor ligands of the LPA GPCR tested with the exception of compounds 53 and 55, which were full albeit weak agonists of LPA . At the present time, very few LPA $\mathrm{L}_{5}$ selective compounds have been described in the literature ${ }^{52}$ hence the identification of these two 
Table 3.3. Characterization at LPA Receptors.

\begin{tabular}{|c|c|c|c|c|c|c|c|c|c|}
\hline \multirow[t]{2}{*}{ Compound } & \multirow{2}{*}{$\begin{array}{l}\text { RH7777 } \\
\text { Vector } \\
\text { E }_{\max 10 \mu \mathrm{M}} \\
(\% \text { of ATP) }\end{array}$} & \multirow{2}{*}{$\begin{array}{l}\mathbf{L P A}_{1} \\
\left(\mathrm{E}_{\max 10 \mu \mathrm{M}}\right)\end{array}$} & \multirow{2}{*}{$\begin{array}{l}\mathbf{L P A}_{2} \\
\left(\mathrm{I}_{\operatorname{max10\mu M}}\right)\end{array}$} & \multirow{2}{*}{$\begin{array}{l}\mathbf{L P A}_{3} \\
\left(\mathbf{E}_{\max 10 \mu \mathrm{M}}\right)\end{array}$} & \multirow{2}{*}{$\begin{array}{l}\text { CHO Vector } \\
\mathbf{E}_{\max 10 \mu \mathrm{M}} \\
(\% \text { of ATP) }\end{array}$} & \multirow[t]{2}{*}{$\mathrm{LPA}_{4}$} & \multirow{2}{*}{$\begin{array}{l}\text { B103 Vector } \\
\mathbf{E}_{\max 10 \mu \mathrm{M}} \\
(\% \text { of } \mathrm{ATP})\end{array}$} & \multicolumn{2}{|c|}{$\mathbf{L P A}_{5}$} \\
\hline & & & & & & & & $\overline{\left(E_{\max 10 \mu M}\right)}$ & $\left(I_{\max 10 \mu M}\right)$ \\
\hline 30 & $>1$ & $\mathrm{NE}$ & 23 & 22 & $>1$ & $\mathrm{NE}$ & $>3$ & $\mathrm{NE}$ & $\mathrm{NE}$ \\
\hline $38 b$ & $>6$ & $\mathrm{NE}$ & $\mathrm{NE}$ & 33 & $>1$ & $\mathrm{NE}$ & $>3$ & 17 & $\mathrm{NE}$ \\
\hline 45 & $>1$ & $\mathrm{NE}$ & 28 & $\mathrm{NE}$ & $\mathrm{NE}$ & $\mathrm{NE}$ & $\mathrm{NE}$ & $\mathrm{NE}$ & 51 \\
\hline 49 & $>3$ & $\mathrm{NE}$ & 26 & 17 & $>5$ & $\mathrm{NE}$ & $>1$ & $\mathrm{NE}$ & $\mathrm{NE}$ \\
\hline 51 & $>5$ & $\mathrm{NE}$ & $\mathrm{NE}$ & $\mathrm{NE}$ & $>5$ & $\mathrm{NE}$ & $>2$ & $\mathrm{NE}$ & $\mathrm{NE}$ \\
\hline 50 & $>15$ & ND & $\mathrm{ND}$ & $\mathrm{ND}$ & $>74$ & ND & $>32$ & $\mathrm{ND}$ & ND \\
\hline 53 & $>6$ & $\mathrm{NE}$ & 50 & 13 & $>14$ & $\mathrm{NE}$ & $>2$ & $\begin{array}{l}100 \\
\left(\mathrm{EC}_{50}=\right. \\
7.9 \mu \mathrm{m})\end{array}$ & $\mathrm{NE}$ \\
\hline 55 & $>7$ & 10 & $\mathrm{NE}$ & 44 & $>14$ & $\mathrm{NE}$ & $>3$ & $\begin{array}{l}100 \\
\left(\mathrm{EC}_{50}=\right. \\
2.9 \mu \mathrm{m})\end{array}$ & $\mathrm{NE}$ \\
\hline
\end{tabular}

$\mathrm{NE}$ - no effect, ND - not definable due to effect on vector transfected cells, $\mathrm{E}_{\mathrm{MAX} 10 \mu \mathrm{M}}$ - maximal response at $10 \mu \mathrm{M}$ relative to the maximal response to either ATP in vector transfected cells or to LPA in LPA receptor expressing cells. 
hits might serve as a starting point for a more comprehensive characterization of the structure-activity relationship of this receptor subtype.

\section{ATX Inhibitors Block Hepatocarcinoma Invasion of Mesothelial and HUVEC Monolayers}

Cancer metastasis is a complex process that cannot be accurately modeled in vitro. Models that utilize cellular monolayers for the invasion of carcinoma cell come the closest to the situation in vivo. ${ }^{181-184}$ Here we used two different cell monolayers, mouse mesothelium and human vascular endothelium to examine the role of ATX in the invasion of MM1 hepatocarcinoma cells. The mesothelial monolayer is an accepted model for invasion of body cavities lined by serous cells whereas, the HUVEC monolayer is considered to be an in vitro model of hematogenous invasion of carcinomas.

The mesothelial and HUVEC cells of the monolayer and the invading MM1 cells express different levels of ATX (Figure 3.3A-C). Quantitative real-time PCR performed with mRNA isolated from MM1, mesothelium and HUVEC cells showed that the primary source of ATX is the MM1 cell as the other two cell types showed very low expression. MM1 cells showed robust expression of transcripts encoding the P2Y family of LPA receptors and $\mathrm{LPA}_{2}$ in the EDG receptor subfamily. In mesothelial cells $\mathrm{LPA}_{2}$ is the predominant receptor whereas, in HUVECs it is the $\mathrm{LPA}_{5}$ receptor.

Addition of LPC to the co-culture increases invasion in a dose-dependent manner (Figure 3.3D). We hypothesized that inhibition of ATX by our two lead compounds should attenuate LPA production in situ and reduce invasion of MM1 carcinoma cells through the mesothelial and HUVEC monolayers. Compounds 30 and $38 \mathrm{~b}$ were applied with or without LPC to the co-cultures and the number of invading cells was quantified after $24 \mathrm{~h}$ of the co-culture (Figure 3.3E). Both compounds inhibited MM1 cell invasion reaching a complete inhibition of LPA and likely ATX-dependent invasion above $3 \mu \mathrm{M}$. The two compounds were also tested for their ability to inhibit MM1 cell invasion of HUVEC monolayers (Figure 3.3F). Similarly to that seen for the invasion of murine mesothelial monolayers, compounds 30 and $38 \mathrm{~b}$ dose-dependently inhibited the LPC-dependent invasion of the HUVEC monolayer whereas, the compounds alone did not reduce the basal rate of invasion. These results provide evidence that the inhibition of ATX in situ can fully inhibit LPC-dependent invasion of carcinoma cells suggesting the potential applicability of our compounds in animal models of carcinoma metastasis. This study was performed in Dr. Tigyis Laboratory.

\section{ATX Inhibitors Reduce B16 Melanoma Metastasis In Vivo}

Inhibitors of ATX have been shown to reduce tumor metastasis in different animal models. ${ }^{9,170}$ Here we applied the syngeneic B16-F10 mouse melanoma model of hematogenous lung metastasis in $\mathrm{C} 57 \mathrm{BL} / 6$ mice that we previously showed responds to inhibitors of $\mathrm{ATX} .{ }^{9} \mathrm{C} 57 \mathrm{BL} / 6$ mice were inoculated with B16-F10 melanoma cells via the 


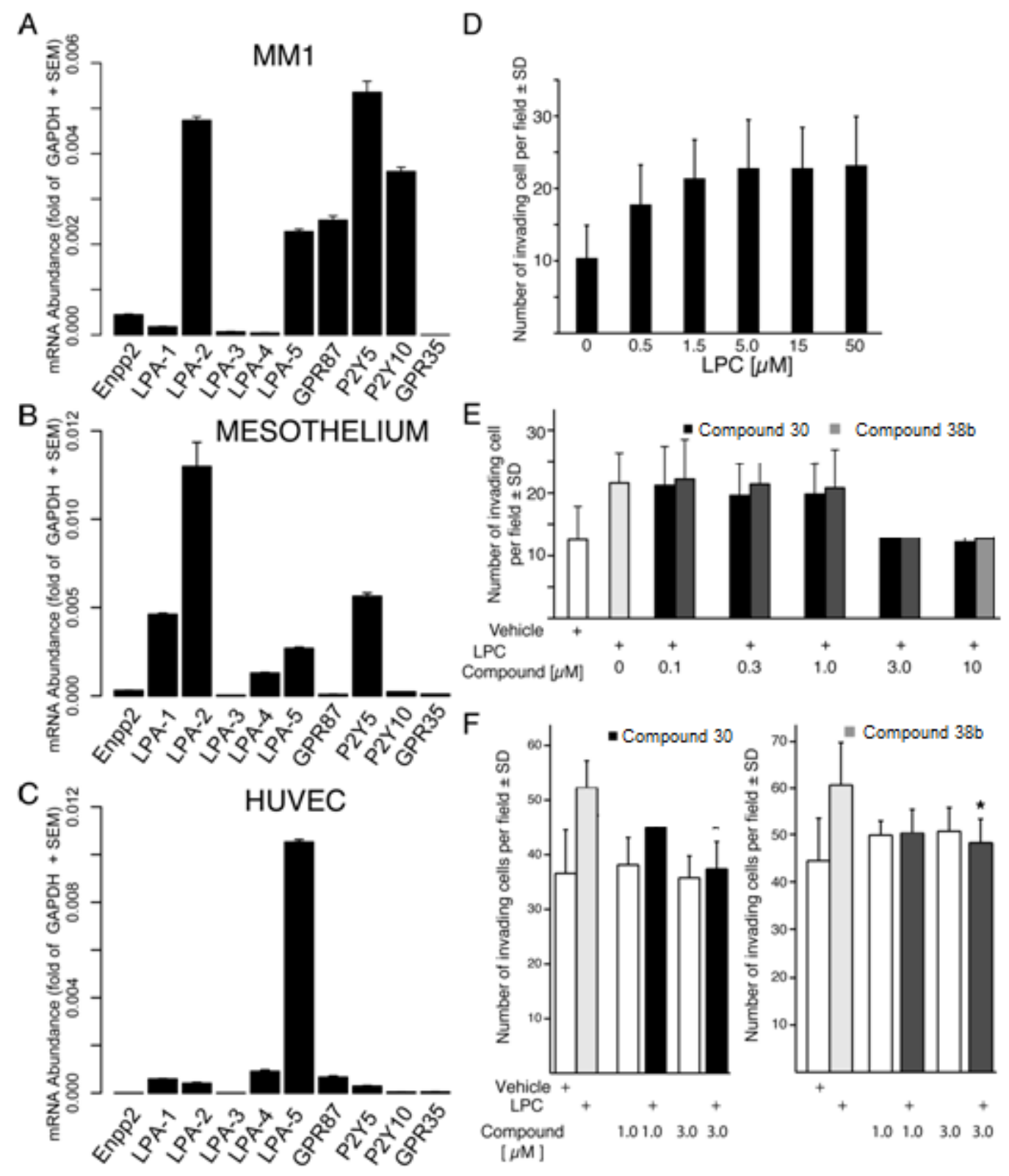

Figure 3.3. Profiling of LPA Receptor and ATX Transcripts.

MM1cells (A), mouse mesothelial (B) and HUVEC cells (C) using quantitative real-time PCR. (D) LPC dose-dependently increases the invasion of mesothelial monolayers by MM1 cells. (E) Compounds 30 and 38b dose dependently inhibit the invasion of mesothelial monolayers induced by LPC $(1.5 \mu \mathrm{M})$ that is reduced to the level of control at and above $3 \mu \mathrm{M}$ concentration. (F) Compounds 30 and $38 \mathrm{~b}$ block LPC-induced but do not alter the basal rate of invasion of HUVEC monolayers by MM1 cells. * Denotes $\mathrm{p}<0.05$ based on Student's t-test. 
tail vein. Beginning $30 \mathrm{~min}$ later the mice were treated with either $0.5 \mathrm{mg} / \mathrm{kg} /$ injection of the two lead compounds or vehicle (PBS with 1\% DMSO) via the intraperitoneal route for an additional 10 days. As a positive control, we also applied LPA-BP that we showed previously to inhibit the metastasis of breast and colon cancers in xenograft models. ${ }^{170,185}$ On day 21 the animals were sacrificed and the lungs were isolated and metastatic nodules in the lungs were quantified (Figure 3.4). In this metastasis model, compounds 30 and $38 \mathrm{~b}$ In the present study we provide evidence for the potential therapeutic utility of ATX inhibitors derived from the benzyl phosphonic acid scaffold. The in vivo testing was carried out at the MD Anderson Cancer Center by Dr.Mills Laboratory. We have modified and expanded this scaffold to 6-substituted naphthalene-methyl phosphonic acid derivatives that were also effective inhibitors of ATX. Our limited structure-activity analysis showed that some of these compounds are high potency inhibitors of ATX without significant effects on LPA GPCR in the nanomolar and low micromolar range. Unlike the parent compound S32826 that lacked activity in cellular assays, ${ }^{177}$ these novel analogs showed strong inhibition of ATX-mediated tumor cell invasion of mesothelial and endothelial cell monolayers and were as effective in vivo as the previously reported dual action ATX inhibitor and LPA GPCR antagonist LPA-BP. ${ }^{9,170,185}$

There is increasing interest in developing inhibitors of ATX to control the tumor promoting and pro-inflammatory roles of LPA. ${ }^{166,167,170,172-175,186}$ Carba cyclicphosphatidic acid was the first ATX inhibitor scaffold explored to control carcinoma invasion and metastasis in vivo. ${ }^{9}$ Carba cyclic-phosphatidic acid inhibited ATX without activating $\mathrm{LPA}_{1-4}$. However, these compounds activate LPA 5 that complicates their utility. ${ }^{52}$ Subsequently, the sn-1 or sn-2 hydroxy groups of LPA have been replaced by fluorine, difluoromethyl, difluoroethyl, O-methyl or O-hydroxyethoxy groups to give non-migrating LPA analogues that resist acyltransferases ${ }^{187}$ and some of these compounds, including LPA-BP, have been found to possess dual action by inhibiting ATX and LPA GPCR. ${ }^{170}$ LPA-BP inhibited breast cancer metastasis and tumor growth in vivo. ${ }^{170}$ Several new ATX inhibitor scaffolds have been reported recently, ${ }^{166,167,172-175,186}$ however, these compounds have not been evaluated at other members of the NPP family and were not explored for their ability to control invasion and/or metastasis. Our study for the first time provides proof of the principle that non-lipid ATX inhibitors are capable of controlling cancer metastasis in vivo and also validate the monolayer invasion assay as a valuable cell-based screening for antimetastatic compounds.

The preclinical screening template consisting of assaying the activity of analogs against ATX, followed by related NPP isoforms, LPA GPCR, monolayer invasion assays, followed by the syngeneic animal metastasis model offers a comprehensive stepwise protocol for the identification of ATX inhibitors with utility to control tumor progression. Given the relatively short half-life of $\mathrm{ATX}^{188}$ and the high rate of LPA turnover in vivo ${ }^{167}$ we foresee the need of compounds with long plasma half-life and broad tissue distribution to control the constitutive production of ATX and the generation of LPA. The present data derived from cellular and in vivo experiments suggest that further modification of the benzyl and naphthyl phosphonic acid scaffolds might yield suitable derivatives for the control of carcinoma metastasis. Pharmacokinetic profiling will be a 

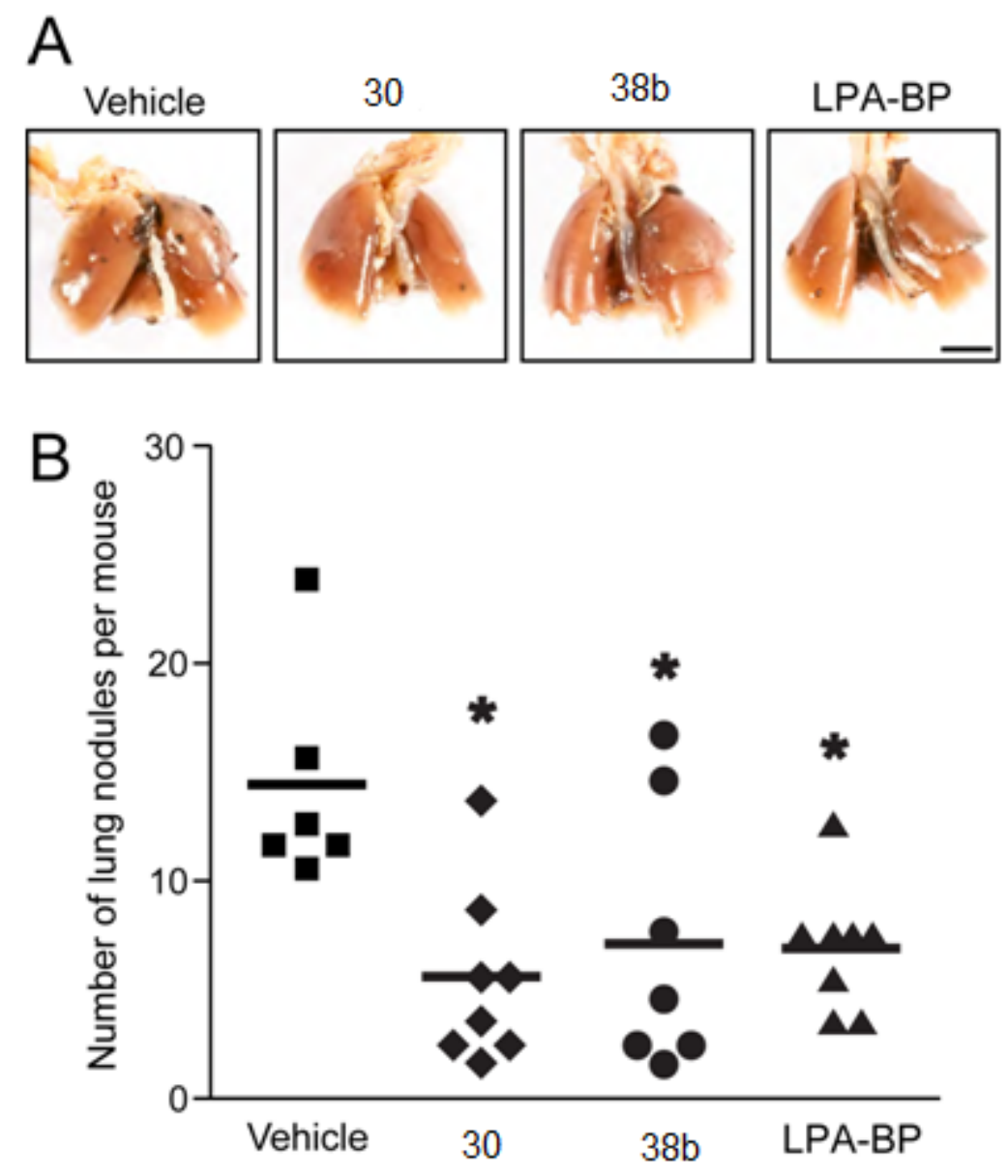

Figure 3.4. Effect of Compound 30, 38b, and LPA-BP on the Lung Metastasis of B16-F10 Melanoma.

(A) Representative lungs taken from the treatment groups. (B) Lung nodule counts in the treatment groups. ${ }^{*}$ Denotes $\mathrm{p}<0.05$ relative to vehicle. 
crucially important step in further evaluation and preclinical development of ATX inhibitors and such experiments are underway in our laboratories.

\section{Experimental Section}

\section{Chemistry}

All starting materials, reagents and solvents were obtained from commercial suppliers and were used without further purification. Reactions were performed under an inert atmosphere of argon, unless otherwise specified. Routine thin-layer chromatography (TLC) was performed on silica gel plates (Analtech, Inc., 250 microns). Flash chromatography was conducted on silica gel (Merck, grade 60, 230-400 mesh). ${ }^{1} \mathrm{H}$ NMR spectra were recorded on a Bruker ARX 300 spectrometer $(300 \mathrm{MHz})$ or Varian spectrometer $(500 \mathrm{MHz})$ using $\mathrm{DMSO}-d_{6}$ and $\mathrm{CDCl}_{3}$ as solvents, and spectral data were consistent with assigned structures. Chemical shift values were reported as parts per million $(\delta)$, coupling constants $(J)$ are given in $\mathrm{Hz}$, and splitting patterns are designated as follows: s, singlet; $d$, doublet; $t$, triplet; q, quartet; $m$, multiplet. Mass spectra were collected on a Brucker ESQUIRE electrospray/ion (ESI) trap instrument in the positive and negative modes. High-resolution mass (HRMS) measurements were obtained using a Micromass Q-TOF2 mass spectrometer. Elemental analyses $(\mathrm{C}, \mathrm{H}, \mathrm{N})$ was performed by Atlantic Microlab, Inc. (Norcross, GA), and results were within $\pm 0.4 \%$ of the theoretical values for the formula given.

Diethyl 4-(hexadecylsulfonamido)benzylphosphonate (11):1-hexadecanesulfonyl chloride $10(0.66 \mathrm{~g}, 2.05 \mathrm{mmol})$ was added to a mixture of $9(0.5 \mathrm{~g}, 2.05 \mathrm{mmol})$ and $N, N$-diisopropylethylamine $(0.04 \mathrm{~g}, 2.05 \mathrm{mmol})$ in THF and refluxed for $24 \mathrm{~h}$ to obtain compound 11. The reaction mixture was concentrated under high vacuum and purified by flash column chromatography $\left(\mathrm{CHCl}_{3} / \mathrm{MeOH} 3: 1\right)$ to give $0.524 \mathrm{~g}$ of pure $11(0.524 \mathrm{~g}$, $48 \%$ ) as a yellow solid. ${ }^{1} \mathrm{H}$ NMR (300 MHz, [D $]$ DMSO): $\delta=9.71(\mathrm{~s}, 1 \mathrm{H}), 7.10-7.25$ (overlapping signals, $4 \mathrm{H}) 3.897-3.948(\mathrm{p}, 4 \mathrm{H}, J=7.8 \mathrm{~Hz}), 3.11-3.18(\mathrm{~d}, 2 \mathrm{H}, J=21 \mathrm{~Hz})$ $3.07-2.95(\mathrm{t}, 2 \mathrm{H}, J=9 \mathrm{~Hz}) 1.7-1.56(\mathrm{p}, 2 \mathrm{H}) 1.231(\mathrm{~s}, 26 \mathrm{H}) 1.171-1.123(\mathrm{t}, 6 \mathrm{H}, J=7.2)$ 0.9-0.8 (t, 3H); MS (ESI) m/z 530.2 [M-H]-.

General procedure for synthesis of Phosphonic acid analogs (Compounds 12, 18, 26, 30, 38a, 38b, 42a, 42b, 45, 49, 50 and 51) (GP 1): To a suspension of phosphonate derivative ( 1 equiv) in anhydrous acetonitrile, $\mathrm{TMSBr}$ ( 2.5 equiv) was added and the reaction mixture was refluxed for $1 \mathrm{~h}$. The acetonitrile was then evaporated under reduced pressure and $\mathrm{MeOH}$ was added to the residue and stirred for 30 minutes at RT. The desired product was obtained in good yield after filtration of $\mathrm{MeOH}$ solution as a white solid.

General procedure for synthesis of compounds 16, 24, 28, 36a, 36b, 40a, 40b and 48 (GP 2): $\mathrm{PBr}_{3}(0.3$ equiv) was added slowly under stirring to a solution of alcohol derivative ( 1 equiv) in anhydrous $\mathrm{DCM}$ at $0^{\circ} \mathrm{C}$. The reaction mixture was stirred at room 
temperature for $1 \mathrm{~h}$ and the formation of the product was monitored by TLC. Water was added at $0^{\circ} \mathrm{C}$ to quench the reaction, extracted from the $\mathrm{DCM}$ and dried over $\mathrm{MgSO}_{4}$. The product was carried on to the next step without further purification.

General procedure for synthesis of compounds 17, 25, 29, 37a, 37b, 41a and 41b (GP 3): Trimethylphosphite (9 equiv) was added to dry bromide derivative (1 equiv)at room temperature and the mixture was refluxed for $18 \mathrm{~h}$. The trimethylphosphite was evaporated under high vacuum overnight and the crude residue was purified by column chromatography $\left(\mathrm{CHCl}_{3} / \mathrm{MeOH} 3: 1\right)$ to give pure compound in quantitative yield.

General procedure for synthesis of compounds 29, 33a and 33b (GP 4): To a mixture of aryl bromide derivative (1 equiv), Palladium (II) acetate ( $5 \mathrm{~mol} \%$ ), and triethyl amine (1 equiv) in anhydrous DMF was added substituted alkene (1 equiv) successively. The reaction mixture was refluxed for $16 \mathrm{~h}$, filtered on bed of celite and extracted with ethylacetate and water. The compound was purified by flash column chromatography using ethyl acetate and hexane (1:2) mixture.

General procedure for synthesis of Compound 22, 27, 34a, 26b, 39a and 31b (GP 5): Anhydrous THF was added to LAH ( 3 equiv) and stirred for 5 minutes. To this, a solution of corresponding methyl ester (1 equiv) in THF was added and the mixture was stirred at room temperature for $4 \mathrm{~h}$. The reaction mixture was cooled to $0^{\circ} \mathrm{C}$ and saturated sodium sulfate was added drop-wise to the mixture. The product was then extracted with ethyl acetate and the crude product was purified using flash column chromatography which was eluted with ethyl acetate and hexane mixture (1:1).

General procedure for the synthesis of compounds23, 27a and 27b (GP 6): To a solution of the corresponding alkene of the methyl ester derivative (1 equiv) in $\mathrm{MeOH}$ was added catalytic amounts of $\mathrm{Pd}(\mathrm{OH})_{2} / \mathrm{C}$ and the mixture was stirred at room temperature for $2 \mathrm{~h}$ using catalytic amount of hydrogen gas. The completion of reaction was monitored by TLC and the reaction mixture was filtered on a bed of celite. The filtrate was evaporated and purified by column chromatography (Chloroform:methanol 30:1).

4-(Hexadecane-1-sulfonylamino)benzyl phosphonic acid (4): According to general procedure GP 1 compound 4 was obtained as a solid $(0.093 \mathrm{gm}, 53 \%) .{ }^{1} \mathrm{H}$ NMR $(500$ MHz, [D 6 DMSO): $\delta=9.66(\mathrm{~d}, 1 \mathrm{H}, J=20 \mathrm{~Hz}) 7.18-7.08(\mathrm{~m}, 4 \mathrm{H}) ; 3.04-2.97(\mathrm{~m}, 2 \mathrm{H})$; 2.91 (d, $2 \mathrm{H}, J=20 \mathrm{~Hz})$; $1.64-1.61(\mathrm{~m}, 2 \mathrm{H}) 1.3-1.2(\mathrm{~s}, 26 \mathrm{H}) 0.86-0.83(\mathrm{t}, 3 \mathrm{H}, J=6 \mathrm{~Hz})$; MS (ESI) m/z 474.0 [M-H]-; Anal Calcd. For $\mathrm{C}_{23} \mathrm{H}_{42} \mathrm{NO}_{5} \mathrm{PS}: \mathrm{C}, 58.08 ; \mathrm{H}, 8.90 ; \mathrm{N}, 2.94$. Found: C, 58.31; H, 9.01; N, 2.92 .

4-(Tetradecyloxy)phenyl methanol (15): Anhydrous $\mathrm{K}_{2} \mathrm{CO}_{3}(0.556 \mathrm{~g}, 4.02 \mathrm{mmol})$ and 18 -crown-6 $(0.02 \mathrm{~g}, 0.076 \mathrm{mmol})$ were added to a solution of $13(0.5 \mathrm{~g}, 4.03 \mathrm{mmol})$ in acetone $(20 \mathrm{~mL})$ and the mixture was refluxed for $16 \mathrm{~h}$. The acetone was evaporated and the residue was partitioned between water and $\mathrm{CH}_{2} \mathrm{Cl}_{2}$. Pure compound $15(1.11 \mathrm{gm}$, $86 \%$ ) was obtained after flash column chromatography $\left(\mathrm{CHCl}_{3} \mathrm{MeOH} 3: 1\right) .{ }^{1} \mathrm{H} \mathrm{NMR}$ $\left(300 \mathrm{MHz}, \mathrm{CDCl}_{3}\right) \delta=7.27(\mathrm{~d}, 2 \mathrm{H}) ; 6.9(\mathrm{~d}, 2 \mathrm{H}) ; 4.6(\mathrm{~d}, 2 \mathrm{H}) ; 3.9(\mathrm{t}, 2 \mathrm{H}) ; 1.8(\mathrm{p}, 2 \mathrm{H}) ; 1.3$ (s, 20H); 0.8 (t, 3H); MS (ESI) m/z 319.0 [M-H]-. 
Dimethyl-4-(tetradecyloxy)benzylphosphonate (25): Compound 25 was obtained according to GP 3. ${ }^{1} \mathrm{H}$ NMR $\left(300 \mathrm{MHz}, \mathrm{CDCl}_{3}\right) \delta=7.2(\mathrm{~d}, 2 \mathrm{H}) ; 6.9(\mathrm{~d}, 2 \mathrm{H}) ; 3.93(\mathrm{t}, 2 \mathrm{H})$; $3.68(\mathrm{~d}, 6 \mathrm{H}, J=10.8 \mathrm{~Hz}) ; 3.1(\mathrm{~d}, 2 \mathrm{H}, J=21 \mathrm{~Hz}) ; 1.8(\mathrm{~m}, 2 \mathrm{H}) ; 1.3(\mathrm{~s}, 20 \mathrm{H}) ; 0.88(\mathrm{t}, 3 \mathrm{H})$; MS (ESI) $\mathrm{m} / \mathrm{z} 435.4[\mathrm{M}+\mathrm{Na}]^{+}$.

4-(Tetradecyloxy)benzylphosphonic acid (18): The acid 18 was prepared similar to the GP 1and it was obtained as a white solid $(0.137 \mathrm{gm}, 54 \%) .{ }^{1} \mathrm{H}$ NMR $\left(500 \mathrm{MHz},\left[\mathrm{D}_{6}\right]\right.$ DMSO): $\delta=7.135(\mathrm{~d}, 2 \mathrm{H}) ; 6.82(\mathrm{~d}, 2 \mathrm{H}) ; 3.91(\mathrm{t}, 2 \mathrm{H}) ; 2.8(\mathrm{~d}, 2 \mathrm{H}, J=21 \mathrm{~Hz}) ; 1.69(\mathrm{~m}$, 2H); 1.386 (m, 2H); 1.24 (s, 22H); 0.85 (t, 3H); MS (ESI) m/z 383.0 [M-H]-; Anal calcd. For $\mathrm{C}_{21} \mathrm{H}_{37} \mathrm{NO}_{4} \mathrm{P}: \mathrm{C}, 65.60 ; \mathrm{H}, 9.70$. Found $\mathrm{C}, 65.83 ; \mathrm{H}, 9.81$.

(E)-Methyl-4-(pentadec-1-enyl)benzoate (21): Compound 21 was prepared according to GP 4. ${ }^{1} \mathrm{H}$ NMR $\left(300 \mathrm{MHz}, \mathrm{CDCl}_{3}\right) \delta=7.92-7.5$ overlapping protons $(\mathrm{m}, 4 \mathrm{H}) ; 6.4$ $(\mathrm{m}, 1 \mathrm{H}) ; 5.4(\mathrm{~m}, 1 \mathrm{H}) ; 3.92(\mathrm{~s}, 3 \mathrm{H}) ; 2.1-1.9(\mathrm{~m}, 2 \mathrm{H}) ; 1.7-1.5(\mathrm{~m}, 2 \mathrm{H}) ; 1.3(\mathrm{~s}, 20 \mathrm{H}) ; 0.865$ $(\mathrm{t}, 3 \mathrm{H}) . \mathrm{MS}(\mathrm{ESI}) \mathrm{m} / \mathrm{z} 367.3[\mathrm{M}+\mathrm{Na}]^{+}$.

(E)-4-(Pentadec-1-enyl)phenyl methanol (22): Compound 22 was synthesized according to GP 5. ${ }^{1} \mathrm{H}$ NMR (300 MHz, $\left.\mathrm{CDCl}_{3}\right) \delta=7.6-7.1$ overlapping protons (m, $\left.4 \mathrm{H}\right)$; 6.4-6.2 $(\mathrm{m}, 1 \mathrm{H}) ; 5.5-5.3(\mathrm{~m}, 1 \mathrm{H}) ; 4.67(\mathrm{~s}, 3 \mathrm{H}) ; 2.1-1.9(\mathrm{~m}, 2 \mathrm{H}) ; 1.7-1.5(\mathrm{~m}, 2 \mathrm{H}) ; 1.27(\mathrm{~s}, 20 \mathrm{H})$; $0.895(\mathrm{t}, 3 \mathrm{H}) . \mathrm{MS}(\mathrm{ESI}) \mathrm{m} / \mathrm{z} 339.5[\mathrm{M}+\mathrm{Na}]^{+}$.

Methyl-4-pentadecylbenzoate (23): The compound was verified with Mass spectrometry and carried on to the next step. MS (ESI) $\mathrm{m} / \mathrm{z} 347.3([\mathrm{M}+\mathrm{H}]) ; \mathrm{m} / \mathrm{z} 369.3[\mathrm{M}+\mathrm{Na}]^{+}$.

(E)-Dimethyl-4-(pentadec-1-enyl)benzylphosphonate (25): Compound 25 was obtained according to GP 3. ${ }^{1} \mathrm{H}$ NMR $\left(300 \mathrm{MHz}, \mathrm{CDCl}_{3}\right) \delta=7.3-7.1$ overlapping protons (m, $\left.4 \mathrm{H}\right)$; 6.4-6.2 (m,1H); 5.5-5.3 (m,1H); 3.65 (d, 6H); $3.2(\mathrm{~d}, 2 \mathrm{H}) ; 2.1-1.9(\mathrm{~m}, 2 \mathrm{H}) ; 1.7-1.57$ $(\mathrm{m}, 2 \mathrm{H}) ; 1.27-1.2(\mathrm{~s}, 20 \mathrm{H}) ; 0.895(\mathrm{t}, 3 \mathrm{H}) . \mathrm{MS}(\mathrm{ESI}) \mathrm{m} / \mathrm{z} 431.3[\mathrm{M}+\mathrm{Na}]^{+}$.

(E)-4-(Pentadec-1-enyl)benzylphosphonic acid (18): Compound 18 was prepared similar to GP 1and was obtained as a white powder $(0.047 \mathrm{gm}, 51 \%) .{ }^{1} \mathrm{H}$ NMR $\left(500 \mathrm{MHz},\left[\mathrm{D}_{6}\right]\right.$ DMSO): $\delta=7.281-7.07$ overlapping protons $(\mathrm{m}, 4 \mathrm{H}) ; 6.36-6.22(\mathrm{~m}, 1 \mathrm{H}) ; 5.36(\mathrm{~m}, 1 \mathrm{H})$; 2.93(d, 2H); $2.15(\mathrm{~d}, 2 \mathrm{H}) ; 1.95(\mathrm{~m}, 2 \mathrm{H}) ; 1.57(\mathrm{~m}, 2 \mathrm{H}) ; 1.237(\mathrm{~s}, 20 \mathrm{H}) ; 0.853(\mathrm{t}, 3 \mathrm{H}) . \mathrm{MS}$ (ESI) m/z 379.0 [M-H]-; HRMS (QTOF) for $\mathrm{C}_{22} \mathrm{H}_{37} \mathrm{O}_{3} \mathrm{P}$, calcd: 379.2402; found: 379.2412 .

(4-Pentadecylphenyl)methanol (27): Compound 27 was obtained according to GP 5, verified with Mass spectrometry and carried on to the next step. MS (ESI) m/z 341 $[\mathrm{M}+\mathrm{Na}]^{+}$.

Dimethyl-4-pentadecylbenzylphosphonate (29): Compound 29 was synthesized similar to GP 3. ${ }^{1} \mathrm{H}$ NMR (300 MHz, $\left.\mathrm{CDCl}_{3}\right) \delta=7.4-7.0$ overlapping protons (m, 4H); 3.66-3.63 $(\mathrm{d}, 6 \mathrm{H}, J=15 \mathrm{~Hz}) ; 3.2(\mathrm{~d}, 2 \mathrm{H}) ; 2.6(\mathrm{~m}, 2 \mathrm{H}) ; 1.6(\mathrm{~m}, 2 \mathrm{H}) ; 1.2(\mathrm{~s}, 24 \mathrm{H}) ; 0.895(\mathrm{t}, 3 \mathrm{H}) . \mathrm{MS}$ (ESI) $\mathrm{m} / \mathrm{z} 433[\mathrm{M}+\mathrm{Na}]^{+}$. 
4-Pentadecylbenzylphosphonic acid (30): Compound 30 was obtained according to GP 1 as a white powder $(0.153 \mathrm{gm}, 53 \%) .{ }^{1} \mathrm{H}$ NMR (500 MHz, [D 6 DMSO): $\delta=7.139-7.063$ overlapping protons $(\mathrm{m}, 4 \mathrm{H}) ; 2.91(\mathrm{~d}, 2 \mathrm{H}, J=20 \mathrm{~Hz}) ; 1.52(\mathrm{~m}, 2 \mathrm{H}) ; 1.26(\mathrm{~m}, 2 \mathrm{H})$; $1.15(\mathrm{~s}, 24 \mathrm{H}) ; 0.853(\mathrm{t}, 3 \mathrm{H})$. MS (ESI) m/z 381.0 [M-H] ; Anal Calcd.for $\mathrm{C}_{22} \mathrm{H}_{39} \mathrm{O}_{3} \mathrm{P} ; \mathrm{C}$, 69.08; H, 10.28; Found C, 69.33; H, 10.52.

(E)-methyl-6-(dodec-1-enyl)-2-naphthoate (25a): According to GP 4 compound 25a was prepared. ${ }^{1} \mathrm{H}$ NMR $\left(300 \mathrm{MHz},\left[\mathrm{D}_{6}\right] \mathrm{DMSO}\right): \delta=8.582-7.771$ overlapping protons $(6 \mathrm{H})$; 6.65-6.52 (m, 1H); 5.7-5.2 (m,1H); 3.91-3.90 (s, 3H); 2.1-1.8 (m, 2H); 1.76-1.55(m, 2H); $1.209(\mathrm{~s}, 14 \mathrm{H}) ; 0.856(\mathrm{t}, 3 \mathrm{H})$. MS (ESI) $\mathrm{m} / \mathrm{z} 375.3[\mathrm{M}+\mathrm{Na}]^{+}$.

(E)-Methyl-6-(tridec-1-enyl)-2-naphthoate(25b): Compound 25b was prepared similar to GP 4. ${ }^{1} \mathrm{H}$ NMR $\left(300 \mathrm{MHz}, \mathrm{CDCl}_{3}\right) \delta=8.582-7.771$ overlapping protons $(6 \mathrm{H}) ; 6.65-6.52$ $(\mathrm{m}, 1 \mathrm{H}) ; 5.7-5.2(\mathrm{~m}, 1 \mathrm{H}) ; 3.91-3.90(\mathrm{~s}, 3 \mathrm{H}) ; 2.1-1.8(\mathrm{~m}, 2 \mathrm{H}) ; 1.76-1.55(\mathrm{~m}, 2 \mathrm{H}) ; 1.209$ $(\mathrm{s}, 14 \mathrm{H}) ; 0.856(\mathrm{t}, 3 \mathrm{H})$. MS (ESI) $\mathrm{m} / \mathrm{z} 389.3[\mathrm{M}+\mathrm{Na}]^{+}$.

(E)-6-(Dodec-1-enyl) naphthalen-2-yl-methanol (34a): Compound 34a was obtained according to GP 5. ${ }^{1} \mathrm{H}$ NMR $\left(300 \mathrm{MHz}, \mathrm{CDCl}_{3}\right) \delta=7.9-7.3$ overlapping protons $(6 \mathrm{H})$; 6.6-6.3 (m, 1H); 5.6-5.4 (m,1H); 4.814(s, 2H); 2.35-2.26 (m, 2H); 1.6-1.47(m, 2H); $1.268(\mathrm{~s}, 14 \mathrm{H}) ; 0.9(\mathrm{t}, 3 \mathrm{H})$. MS (ESI) $\mathrm{m} / \mathrm{z} 347.3[\mathrm{M}+\mathrm{Na}]^{+}$.

(E)-6-Tridec-1-enyl-naphthalen-2-yl-methanol (34b): Compound 34b was prepared according to GP 5. ${ }^{1} \mathrm{H}$ NMR $\left(300 \mathrm{MHz}, \mathrm{CDCl}_{3}\right) \delta=7.72-7.27$ overlapping protons $(6 \mathrm{H})$; 6.6-6.3 (m, 1H); 5.6-5.4 (m,1H); 4.75(s, 2H); 2.35-2.26 (m, 2H); 1.6-1.47(m, 2H); $1.268(\mathrm{~s}, 18 \mathrm{H}) ; 0.893(\mathrm{t}, 3 \mathrm{H}) . \mathrm{MS}(\mathrm{ESI}) \mathrm{m} / \mathrm{z} 361.3[\mathrm{M}+\mathrm{Na}]^{+}$.

6-Dodecylnaphthalene-2-carboxylic acid methyl ester (27a): Compound 27a was prepared according to GP 6 and confirmed by Mass spectrometry. MS (ESI) m/z 355 $[\mathrm{M}+\mathrm{H}]^{+}$.

6-Tridecylnaphthalene-2-carboxylic acid methyl ester (27b): Compound 27a was prepared similar to GP 6 and confirmed by Mass spectrometry. MS (ESI) m/z 369.3 $[\mathrm{M}+\mathrm{H}]^{+}$.

(E)-Dimethyl-6-dodec-1-enyl-naphthalen-2-yl-methylphosphonate (37a): Compound 37a was obtained according to GP $3 .{ }^{1} \mathrm{H} \mathrm{NMR}\left(300 \mathrm{MHz}, \mathrm{CDCl}_{3}\right) \delta=7.9-7.3$ overlapping protons $(6 \mathrm{H}) ; 6.6-6.3(\mathrm{~m}, 1 \mathrm{H}) ; 5.6-5.4(\mathrm{~m}, 1 \mathrm{H}) ; 3.778-3.741(\mathrm{~d}, 6 \mathrm{H}, J=21.6 \mathrm{~Hz})$; $3.34-3.267$ (d, $2 \mathrm{H}, J=21.9 \mathrm{~Hz}) ; 2.35-2.26(\mathrm{~m}, 2 \mathrm{H}) ; 1.6-1.47(\mathrm{~m}, 2 \mathrm{H}) ; 1.268(\mathrm{~s}, 14 \mathrm{H}) ; 0.9$ $(\mathrm{t}, 3 \mathrm{H}) . \mathrm{MS}(\mathrm{ESI}) \mathrm{m} / \mathrm{z} 439.3[\mathrm{M}+\mathrm{Na}]^{+}$.

(E)-Dimethyl-6-tridec-1-enyl-naphthalen-2-yl-methylphosphonate (37b): Compound 37b was obtained similar to GP 3. ${ }^{1} \mathrm{H}$ NMR $\left(300 \mathrm{MHz} \mathrm{CDCl}_{3}\right) \delta=7.9-7.3$ overlapping protons $(6 \mathrm{H}) ; 6.6-6.3(\mathrm{~m}, 1 \mathrm{H}) ; 5.6-5.4(\mathrm{~m}, 1 \mathrm{H}) ; 3.778-3.741(\mathrm{~d}, 6 \mathrm{H}, J=21.6 \mathrm{~Hz})$; $3.34-3.267$ (d, $2 \mathrm{H}, J=21.9 \mathrm{~Hz}) ; 2.35-2.26(\mathrm{~m}, 2 \mathrm{H}) ; 1.6-1.47(\mathrm{~m}, 2 \mathrm{H}) ; 1.268(\mathrm{~s}, 16 \mathrm{H}) ; 0.9$ $(\mathrm{t}, 3 \mathrm{H}) . \mathrm{MS}(\mathrm{ESI}) \mathrm{m} / \mathrm{z} 453.3[\mathrm{M}+\mathrm{Na}]^{+}$. 
(E)-6-Dodec-1-enyl-naphthalen-2-yl-methylphosphonic acid (30a): According to GP 1 compound $30 \mathrm{a}$ was prepared and was obtained as a white powder $(0.027 \mathrm{gm}, 52 \%) .{ }^{1} \mathrm{H}$ NMR (500 MHz, [D 6 DMSO): $\delta=7.747-7.329$ overlapping protons $(6 \mathrm{H})$; 6.556$6.630(\mathrm{~m}, 2 \mathrm{H}) ; 3.182(\mathrm{~d}, 2 \mathrm{H}, J=21 \mathrm{~Hz}) ; 2.221(\mathrm{~m}, 2 \mathrm{H}) ; 1.468(\mathrm{~m}, 2 \mathrm{H}) ; 1.255(\mathrm{~s}, 14 \mathrm{H})$; $0.836(\mathrm{t}, 3 \mathrm{H})$. MS (ESI) m/z 387.0 [M-H]-; Anal calcd for $\mathrm{C}_{23} \mathrm{H}_{33} \mathrm{O}_{3} \mathrm{P}: \mathrm{C}, 71.11 ; \mathrm{H}, 8.56$; Found: C, 70.73; H, 9.11.

(E)-6-Tridec-1-enyl-naphthalen-2-yl-methylphosphonic acid (38b): Compound 38b was prepared similar to GP 1 and was obtained as a white powder $(0.117 \mathrm{gm}, 54 \%) .{ }^{1} \mathrm{H} \mathrm{NMR}$ (500 MHz, [D 6 DMSO): $\delta=7.811-7.327$ overlapping protons $(6 \mathrm{H}) ; 6.553-6.433(\mathrm{~m}, 1 \mathrm{H})$; $5.353(\mathrm{~m}, 1 \mathrm{H}) ; 3.123-3.080(\mathrm{~d}, 2 \mathrm{H}, J=21.5 \mathrm{~Hz}) ; 2.730(\mathrm{t}, 2 \mathrm{H}) ; 1.98(\mathrm{~m}, 2 \mathrm{H}) ; 1.64-1.48$ $(\mathrm{m}, 2 \mathrm{H}) ; 1.244(\mathrm{~s}, 14 \mathrm{H}) ; 0.841(\mathrm{t}, 3 \mathrm{H}) . \mathrm{MS}(\mathrm{ESI}) \mathrm{m} / \mathrm{z} 401.0[\mathrm{M}-\mathrm{H}]^{-} ;$HRMS Calcd for $\mathrm{C}_{24} \mathrm{H}_{34} \mathrm{O}_{3} \mathrm{P}, 401.2246$; found: 401.2249 .

6-Dodecylnaphthalen-2-yl-methanol (39a): Compound 39a was synthesized according to GP 5. ${ }^{1} \mathrm{H}$ NMR $\left(300 \mathrm{MHz}, \mathrm{CDCl}_{3}\right) \delta=7.9-7.3$ overlapping protons $(6 \mathrm{H}) ; 4.805(\mathrm{~s}, 2 \mathrm{H})$; 2.817-2.792 (m, 2H); $1.833(\mathrm{~m}, 2 \mathrm{H}) ; 1.372$ (s, 16H); 0.963 (t, 3H). MS (ESI) m/z 325.0 $[\mathrm{M}-\mathrm{H}]-; \mathrm{m} / \mathrm{z} 349.3[\mathrm{M}+\mathrm{Na}]^{+}$.

6-Tridecylnaphthalen-2-yl-methanol (39b): Compound 39b was prepared according to GP 5. ${ }^{1} \mathrm{H}$ NMR $\left(300 \mathrm{MHz}, \mathrm{CDCl}_{3}\right) \delta=7.9-7.3$ overlapping protons $(6 \mathrm{H}) ; 4.798(\mathrm{~s}, 2 \mathrm{H})$; 2.857-2.7 (m, 2H); 1.833-1.6 (m,2H); 1.372 (s, 18H); 0.963 (t, 3H). MS (ESI) m/z 363.6 $[\mathrm{M}+\mathrm{Na}]^{+}$.

2-Bromomethyl-6-dodecylnaphthalene (40a): Compound 40a was obtained according to GP 2. ${ }^{1} \mathrm{H}$ NMR $\left(300 \mathrm{MHz}, \mathrm{CDCl}_{3}\right) \delta=7.9-7.3$ overlapping protons $(6 \mathrm{H}) ; 4.696(\mathrm{~s}, 2 \mathrm{H})$; 2.817-2.792 (m, 2H); $1.833(\mathrm{~m}, 2 \mathrm{H}) ; 1.372(\mathrm{~s}, 18 \mathrm{H}) ; 0.968(\mathrm{t}, 3 \mathrm{H})$.

Dimethyl-6-dodecylnaphthalen-2-yl-methylphosphonate (41a): Compound 41a was prepared to according to GP 3. ${ }^{1} \mathrm{H} \mathrm{NMR}\left(300 \mathrm{MHz}, \mathrm{CDCl}_{3}\right) \delta=7.9-7.3$ overlapping protons $(6 \mathrm{H}) ; 3.691-3.655(\mathrm{~d}, 6 \mathrm{H}, J=10.8 \mathrm{~Hz}) ; 3.359-3.287(\mathrm{~d}, 2 \mathrm{H}, J=21.6 \mathrm{~Hz})$; 2.817-2.792 (m, 2H); 1.833-1.6 (m, 2H); $1.302(\mathrm{~s}, 18 \mathrm{H}) ; 0.893(\mathrm{t}, 3 \mathrm{H})$. MS (ESI) m/z $441.3[\mathrm{M}+\mathrm{Na}]^{+}$.

Dimethyl-6-tridecylnaphthalen-2-yl-methylphosphonate (41b): Compound 41b was prepared according to GP 3 and confirmed by Mass spectrometry MS(ESI) m/z 455.3 $[\mathrm{M}+\mathrm{Na}]^{+}$.

6-Dodecylnaphthalen-2-yl-methylphosphonic acid (42a): Compound 42a was obtained according to GP 1 and was obtained as a white powder $(0.023 \mathrm{gm}, 49 \%)$. ${ }^{1} \mathrm{H}$ NMR (500 $\mathrm{MHz},\left[\mathrm{D}_{6}\right.$ ] DMSO): $\delta=7.637-7.326$ overlapping protons $(6 \mathrm{H}) ; 3.13591-3.064(\mathrm{~d}, 2 \mathrm{H}$, $J=21.3 \mathrm{~Hz}) ; 2.927$ (m, 2H); 1.641 (m, 2H);1.263 (s, 18H); 0.849 (t, 3H). MS (ESI) m/z 389.0 [M-H]-. HRMS calcd for $\mathrm{C}_{23} \mathrm{H}_{34} \mathrm{O}_{3} \mathrm{P}, 389.2246$, found: 389.2237.

6-Tridecylnaphthalen-2-yl-methylphosphonic acid (42b): Compound 42b was obtained according to GP 1 and was obtained as a white powder $(0.036 \mathrm{gm}, 51 \%)$. ${ }^{1} \mathrm{H}$ NMR (500 
MHz, [D 6 DMSO): $\delta=7.637-7.326$ overlapping protons $(6 \mathrm{H}) ; 3.13591-3.064(\mathrm{~d}, 2 \mathrm{H}$, $J=21.3 \mathrm{~Hz}) ; 2.927$ (m, 2H); 1.641 (m, 2H);1.263 (s, 18H); 0.849 (t, 3H). MS (ESI) m/z 403.0 [M-H] . Anal calcd for $\mathrm{C}_{23} \mathrm{H}_{33} \mathrm{O}_{3} \mathrm{P}: \mathrm{C}, 71.26$; H, 9.22; Found: C, 70.82; H, 9.17.

4-Pentadecylbenzaldehyde (43): Pyridinium dichromate (0.827gm, 2.20mmol) was added to a solution of $27(1.00 \mathrm{~g}, 3.139 \mathrm{mmol})$ in $\mathrm{CH}_{2} \mathrm{Cl}_{2}$ and stirred the mixture at $\mathrm{RT}$ for $16 \mathrm{~h}$. The completion of reaction was checked by TLC. The reaction mixture was filtered over a bed of silica gel and filtrate was evaporated under reduced pressure to give compound $43(0.854 \mathrm{~g}, 86 \%)$, which was used without any further purification for the next step. MS (ESI) $\mathrm{m} / \mathrm{z} 339.3[\mathrm{M}+\mathrm{Na}]^{+}$.

Hydroxy-4-pentadecylphenylmethyl phosphonic acid dimethyl ester (44):

Dimethylphosphite $(0.547 \mathrm{~mL})$ and triethyl amine $(0.357 \mathrm{~mL})$ were added to dry compound $43(0.953 \mathrm{~g}, 3.011 \mathrm{mmol})$ at $0^{\circ} \mathrm{C}$. The reaction mixture was stirred at RT for 4 $\mathrm{h}$ and the progress of the reaction was monitored by TLC. The crude mixture was purified on a silica gel column using $\mathrm{CHCl}_{3}: \mathrm{MeOH}(30: 1)$ to get compound 44 in $72 \%$ yield (0.926gm). ${ }^{1} \mathrm{H} \mathrm{NMR}\left(500 \mathrm{MHz}, \mathrm{CDCl}_{3}\right) \delta=7.456-7.149$ overlapping protons $(4 \mathrm{H}) ; 6.040$ $(\mathrm{d}, 1 \mathrm{H}) ; 5.03(\mathrm{~d}, 1 \mathrm{H}, \mathrm{J}=11.5) ; 3.77(\mathrm{~d}, 6 \mathrm{H}, \mathrm{J}=15) ; 2.584(\mathrm{t}, 2 \mathrm{H}), 1.601(\mathrm{~m}, 2 \mathrm{H}) ; 1.358(\mathrm{t}, 2 \mathrm{H})$; $1.34(\mathrm{~s}, 20 \mathrm{H}) ; 0.878(\mathrm{t}, 3 \mathrm{H})$. MS (ESI) $\mathrm{m} / \mathrm{z} 449.3[\mathrm{M}+\mathrm{Na}]^{+}$.

Hydroxy-4-pentadecylphenylmethylphosphonic acid (45): Compound 45 was prepared according to GP 1 .and was obtained as a offwhite powder $(0.093 \mathrm{gm}, 52 \%) ;{ }^{1} \mathrm{H}$ NMR (500 MHz, [D $\mathrm{D}_{6}$ DMSO): $\delta=7.332-7.054$ overlapping protons $(4 \mathrm{H}) ; 6.061(\mathrm{~s}, 1 \mathrm{H}) ; 4.629$ $(\mathrm{d}, 1 \mathrm{H}, J=13.5 \mathrm{~Hz}) ; 2.584$ (overlapping with DMSO, 2H), 1.534(m, 2H); 1.067(s, 22H); 0.838 (t, 3H). MS (ESI) m/z 397.0[M-H]-. HRMS calcd for $\mathrm{C}_{22} \mathrm{H}_{38} \mathrm{O}_{4} \mathrm{P}[\mathrm{M}-\mathrm{H}]$ 397.2508; found 397.2517 .

Fluoro-4-pentadecylphenylmethyl phosphonic acid dimethyl ester (46):To a solution of compound $44(0.122 \mathrm{~g}, 0.286 \mathrm{mmol})$ in ether, diethylaminosulfurtrifluoride (DAST) $(0.046 \mathrm{~g}, 0.286 \mathrm{mmol})$ was added at $0^{\circ} \mathrm{C}$ and stirred the reaction mixture at r.t for $1 \mathrm{~h}$. The reaction was quenched by the addition of ice/water, extracted with ether and the crude residue was purified over column chromatography $(0.076 \mathrm{gm}, 62 \%) .{ }^{1} \mathrm{H}$ NMR $(500 \mathrm{MHz}$, $\left.\mathrm{CDCl}_{3}\right) \delta=7.937(\mathrm{~d}, 2 \mathrm{H}) ; 7.227$ (overlapping protons ,2H); $5.731(\mathrm{dd}, 1 \mathrm{H}, \mathrm{J}=44.5 \mathrm{~Hz})$; $3.747(\mathrm{~d}, 6 \mathrm{H}) ; 2.610(\mathrm{t}, 2 \mathrm{H}) ; 1.602(\mathrm{~m}, 2 \mathrm{H}) 1.228(\mathrm{~s}, 24 \mathrm{H}) ; 0.878(\mathrm{t}, 3 \mathrm{H}) . \mathrm{MS}(\mathrm{ESI}) \mathrm{m} / \mathrm{z}$ $451.1[\mathrm{M}+\mathrm{Na}]^{+}$.

Chloro-4-pentadecylphenylmethyl phosphonic acid dimethyl ester (47): Thionyl chloride $(0.047 \mathrm{~g}, 0.397 \mathrm{mmol})$ was added to a solution of compound $44(0.113 \mathrm{~g}, 0.264 \mathrm{mmol})$ in anhydrous $\mathrm{CH}_{2} \mathrm{Cl}_{2}$ and refluxed the reaction mixture for $1 \mathrm{~h}$. The solvent was evaporated under reduced pressure to afford compound 47. MS (ESI) $\mathrm{m} / \mathrm{z} 445.1\left(\mathrm{M}^{+}\right)$.

Bromo-4-pentadecylphenylmethyl phosphonic acid dimethyl ester (48): Compound 48 was obtained according to GP 2 and it was used for the next step without further purification. 
Fluoro-4-pentadecylphenylmethyl phosphonic acid (49): Compound 49 was obtained according to GP $1(0.04 \mathrm{gm}, 53 \%)$. ${ }^{1} \mathrm{H}$ NMR (500 MHz, [D $]$ DMSO): $\delta=7.308$ (m, overlapping protons, $4 \mathrm{H}) ; 6.669(\mathrm{~s}, 1 \mathrm{H}) ;$,2.610 (overlapping DMSO peak , 2H); 1.602 (m, 2H) 1.228 (s, 24H); 0.878 (t, 3H).MS (ESI) m/z 399.0 [M-H]-. HRMS calcd for $\mathrm{C}_{22} \mathrm{H}_{37} \mathrm{FO}_{3} \mathrm{P}([\mathrm{M}-\mathrm{H}])$ 399.2464; found 399.2461.

Chloro-4-pentadecylphenylmethyl phosphonic acid (50): Compound 50 (0.011gm, 47\%) was prepared similar to GP $1 .{ }^{1} \mathrm{H} \mathrm{NMR}\left(500 \mathrm{MHz}, \mathrm{CDCl}_{3}\right) \delta=7.781$ (m,overlapping protons, 4H); $5.050(\mathrm{~s}, 1 \mathrm{H},) ; 2.580(\mathrm{~m}, 2 \mathrm{H}) ; 1.581(\mathrm{~m}, 2 \mathrm{H}) 1.185(\mathrm{~s}, 24 \mathrm{H}) ; 0.875(\mathrm{t}, 3 \mathrm{H})$. MS (ESI) $\mathrm{m} / \mathrm{z} 415.0(\mathrm{M}+)$. HRMS calcd for $\mathrm{C}_{22} \mathrm{H}_{37} \mathrm{ClO}_{3} \mathrm{P}([\mathrm{M}-\mathrm{H}])$ 415.2169; found: 415.2166 .

Bromo-4-pentadecylphenylmethyl phosphonic acid 51: Compound 51 (0.019gm, 52\%) was prepared according to GP $1 .{ }^{1} \mathrm{H}$ NMR (500 MHz, [D 6 DMSO): $\delta=7.409$ (m,overlapping protons, $4 \mathrm{H}) ; 4.781(\mathrm{~s}, 1 \mathrm{H}) ;$,2.580 (overlapping with DMSO, 2H); 1.515 (m, 2H) $1.225(\mathrm{~s}, 24 \mathrm{H}) ; 0.846(\mathrm{t}, 3 \mathrm{H}) . \mathrm{MS}(\mathrm{ESI}) \mathrm{m} / \mathrm{z} 458.9([\mathrm{M}+]) ; \mathrm{m} / \mathrm{z} 460.9([\mathrm{M}+2])$. HRMS calcd for $\mathrm{C}_{22} \mathrm{H}_{37} \mathrm{BrO}_{3} \mathrm{P}([\mathrm{M}-\mathrm{H}])$ 459.1664; found: 459.1664([M-H]); 461.1660(M+2).

Bis(2-cyanoethyl) 4-pentadecylbenzyl phosphate (52): $1 \mathrm{H}$-tetrazole $(0.149 \mathrm{~g}, 2.134 \mathrm{mmol})$ and bis(2-cyanoethyl) $N, N$-diisopropylphosphoramidite $(0.289 \mathrm{~g}, 1.067 \mathrm{mmol})$ were added to a solution of compound $27(0.170 \mathrm{~g}, 0.534 \mathrm{mmol})$ in $\mathrm{CH}_{2} \mathrm{Cl}_{2}$ and the mixture was stirred for $1 \mathrm{~h}$ followed by addition of hydrogen peroxide $(0.12 \mathrm{ml})$ to give compound 52 . MS (ESI) $\mathrm{m} / \mathrm{z} 505.1([\mathrm{M}+\mathrm{H}])$.

O,O-bis(2-cyanoethyl)-O-4-pentadecylbenzyl phosphorothioate (54): compound 27 $(0.173 \mathrm{~g}, 0.543 \mathrm{mmol})$ was treated with a mixture of $1 H$-tetrazole $(0.0760 \mathrm{~g}, 2.172 \mathrm{mmol})$ and bis(2-cyanoethyl) $N, N$-diisopropylphosphoramidite $(0.371 \mathrm{~g}, 1.086 \mathrm{mmol})$ in anhydrous $\mathrm{CH}_{2} \mathrm{Cl}_{2}$ and stirred for $1 \mathrm{~h}$ followed by addition of sulfur $(0.034 \mathrm{~g}, 1.086 \mathrm{mmol})$ to give compound 54. MS (ESI) $\mathrm{m} / \mathrm{z}$ 543.2([M + H]).

Synthesis of 45 and 47:Compound 52 or 54 (1 equiv) was dissolved in methanol and $1 \mathrm{~N}$ methanolic $\mathrm{KOH}$ (1equiv) was added to the reaction mixture. The completion of the reaction was monitored by TLC. The methanol was evaporated and $1 \mathrm{~N} \mathrm{HCl}$ was added and the compound was extracted with $\mathrm{CHCl}_{3}$. Purification of the crude residue by coloumn chromatography $\left(30: 1 \mathrm{CHCl}_{3}: \mathrm{MeOH}\right)$ gave desired compounds 53 and 55 respectively.

4-pentadecylbenzyl dihydrogen phosphate (53): Compound 53 was obtained as a solid (0.087gm, 77\%). ${ }^{1} \mathrm{HNMR}(500 \mathrm{MHz}, \mathrm{CD} 3 \mathrm{OD}) \delta=7.337-7.123$ (m,overlapping protons, 4H); 5.075 (overlapping with CD3OD peak , 2H,); $2.598(\mathrm{t}, 2 \mathrm{H}) ; 1.593(\mathrm{~m}, 2 \mathrm{H})$ 1.184(s, 24H); 0.890 (t, 3H)MS (ESI) m/z 397.0 [M-H]-. HRMS calcd for $\mathrm{C}_{22} \mathrm{H}_{38} \mathrm{O}_{4} \mathrm{P}$ ([M-H]) 397.2508; Found: 397.2511.

O-4-pentadecylbenzyl O,O-dihydrogen phosphorothioate (55): Compound 55 was obtained as a solid (0.073gm, 83\%). ${ }^{1} \mathrm{HNMR}(500 \mathrm{MHz}, \mathrm{CD} 3 \mathrm{OD}) \delta=7.321-7.129$ 
(m,overlapping protons, 4H); 4.955(d, 2H, $J=4 \mathrm{~Hz}) ; 3.581(\mathrm{t}, 2 \mathrm{H}) ; 2.586(\mathrm{t}, 2 \mathrm{H}) ; 1.580$ (m, 2H); 1.199(s, 24H); 0.889 (t, 3H)MS (ESI) m/z 413.0 [M-H]-. HRMS calcd for $\mathrm{C}_{22} \mathrm{H}_{38} \mathrm{O}_{3} \mathrm{PS}([\mathrm{M}-\mathrm{H}])$ 413.2279; Found: 413.2281 .

\section{Biology}

Lysophosphatidic acid (18:1), LPC 18:1, and S1P were purchased from Avanti Polar Lipids (Alabaster, AL). For calcium mobilization assays, LPA, S1P, and the test compounds were prepared as $1 \mathrm{mM}$ stock solutions in phosphate-buffered saline (PBS) in an equimolar complex with charcoal-stripped, fatty acid free bovine serum albumin (BSA; Sigma, St. Louis, MO). The fluorescent ATX substrate FS-3 was purchased from Echelon Biosciences (Salt Lake City, UT).

\section{Autotaxin Inhibition Screening Assay}

As the first level of screen, $50 \mu \mathrm{l}$ of recombinant-ATX ( $2 \mathrm{nM}$ in final concentration) in assay buffer [(Tris $50 \mathrm{mM}, \mathrm{NaCl} 140 \mathrm{mM}, \mathrm{KCl} 5 \mathrm{mM}, \mathrm{CaCl}_{2} 1 \mathrm{mM}, \mathrm{MgCl}_{2} 1 \mathrm{mM}(\mathrm{pH}$ 8.0)] was mixed with $25 \mu \mathrm{L}$ of FS-3 (Echelon Biosciences Biosciences, Inc., Salt lake city, UT; final concentration $1 \mu \mathrm{M}$ ) and $25 \mu \mathrm{l}$ of test compound dissolved in assay buffer with $40 \mu \mathrm{M}$ bovine serum albumin (Sigma, St. Louis, MO) in 96-well Costar black-well plate. FS-3 fluorescence at excitation and emission wavelengths of 485 and $538 \mathrm{~nm}$, respectively, were monitored using a FLEXstation II (Molecular Devices, Sunnyvale, CA) for $2 \mathrm{~h}$ of incubation at $37^{\circ} \mathrm{C}$. The differences between time 0 and $120 \mathrm{~min}$ were calculated individually and normalized to the vehicle control. The mean \pm SD of triplicate samples was expressed as percentage of ATX activity. The ATX activity in the presence of the test compounds was compared to vehicle using the Student's and $p<0.05$ was considered significant.

\section{Determination of the Mechanism of Autotaxin Inhibition}

The mechanism of inhibition of ATX was determined using recombinant, purified human ATX and FS-3 as recently described. ${ }^{172,173,175}$ Final ATX and FS-3 concentrations were $8.3 \mathrm{nM}$ and $1 \mu \mathrm{M}$, respectively and the assay buffer with $15 \mu \mathrm{M}$ fatty acid free BSA. To calculate $\mathrm{IC}_{50}$ full dose responses were determined for the test compounds. In addition, the mechanism of inhibition of ATX-mediate hydrolysis of FS-3 was determined by varying the concentration $(0.3 \mu \mathrm{M}$ to $20 \mu \mathrm{M})$ of substrate in the presence of three concentrations of each inhibitor $\left(0,0.5 \mathrm{x}\right.$ and $\left.2 \mathrm{x}\left(\mathrm{IC}_{50}\right)\right)$. Kinetic data including $\mathrm{V}_{\max }$ and $\mathrm{K}_{\mathrm{m}}$ were determined using KaleidaGraph 4.0 (version 4.03, Synergy Software, Reading, PA) after the plots of initial velocities versus substrate concentration in the absence or presence of inhibitors were fit to the following equation $y=m_{1} * m_{2} * x /\left(1+m_{2} * x\right)$, where $\mathrm{K}_{\mathrm{m}}=1 / \mathrm{m}_{2}$ and $\mathrm{V}_{\max }=\mathrm{m}_{1}$. The average $\mathrm{K}_{\mathrm{m}}$ for ATX-mediated FS-3 hydrolysis was determined to be $2.3 \mu \mathrm{M}$ and was used in the following calculations. Simultaneous nonlinear regression using WinNonLin ${ }^{\circledR} 6.1$ (Pharsight, Mountain View, CA) was used to 
assign the mechanism of inhibition. ${ }^{172,173,175} \mathrm{~K}_{\mathrm{i}}$ and $\mathrm{K}_{\mathrm{i}}$ ' values (the affinity for free enzyme and enzyme substrate complex, respectively) were determined by calculating the lowest averaged percent residuals for each mechanism derived from curve fitting using the Michaelis-Menten equations for competitive, uncompetitive, mixed-mode, and noncompetitive inhibition.

\section{Calcium Mobilization Assays}

Assays for mobilization of intracellular $\mathrm{Ca}^{2+}$ were performed as described. ${ }^{179,189}$ Test compounds up to a final concentration of $10 \mu \mathrm{M}$ either alone or mixed with respective $\sim \mathrm{EC}_{50}$ concentrations of LPA 18:1 for each of LPA receptor subtype were added to cells stably expressing $\mathrm{LPA}_{1.2 .3 .4 .5}$, GPR87, and P2Y10 LPA receptor subtypes. ${ }^{52}$ The cells were loaded with Fura-2/AM in Krebs buffer containing $0.001 \%$ pluronic acid for $1 \mathrm{~h}$, and rinsed with Krebs buffer before measuring $\mathrm{Ca}^{2+}$ mobilization. The $\mathrm{Ca}^{2+}$ responses were measured using a Flex Station II fluorescent plate reader (Molecular Devices, Sunnyvale, CA). The ratio of peak emissions at $510 \mathrm{~nm}$ after $2 \mathrm{~min}$ of ligand addition was determined for excitation wavelengths of $340 \mathrm{~nm} / 380 \mathrm{~nm}$. All samples were run in triplicate, and assays were performed at least two times for each receptor.

\section{NPP-6 and NPP-7 Inhibition Assay}

Inhibition of NPP6 and NPP7 was evaluated using recombinant, purified proteins, the synthetic substrate para-nitrophenylphosphocholine (pNPPC) and a Synergy II plate reader (BioTek, Winooski, VT) as we have previously described. ${ }^{172,175}$ The final concentration of each enzyme was $8.3 \mathrm{nM}$ and pNPPC was $10 \mu \mathrm{M}$. All analogs were tested at single $10 \mu \mathrm{M}$ concentrations. Absorbance of liberated para-nitrophenol at 405 $\mathrm{nm}$ was determined up to 1 hour (where responses were linear) and was normalized to vehicle control.

\section{MM1 Hepatoma Cell Invasion of Endothelial Monolayers}

The highly invasive MM1 cells originally isolated from the AH130 rat hepatoma cells were a kind gift from (Dr. Michiko Mukai, Osaka University ${ }^{171,183}$ ). These cells were grown in suspension in DMEM supplemented with $10 \%$ fetal bovine serum, $2 \mathrm{mM}$ glutamine, $100 \mathrm{units} / \mathrm{ml}$ penicillin and $10 \mu \mathrm{g} / \mathrm{ml}$ streptomycin. The isolation and culture of mesothelial cells from C57BL/6 mice has been previously described elsewhere HUVECs obtained from VEC Technologies Inc., (Rensselaer, NY, USA) were grown in MCDB131 complete medium containing $10 \%$ fetal bovine serum, $90 \mu \mathrm{g} / \mathrm{ml}$ heparin, $10 \mathrm{ng} / \mathrm{ml}$ EGF, $1 \mu \mathrm{g} / \mathrm{ml}$ hydrocortisone, $0.2 \mathrm{mg} / \mathrm{ml}$ EndoGrowth supplement, 100 units $/ \mathrm{ml}$ penicillin $\mathrm{G}, 100 \mu \mathrm{g} / \mathrm{ml}$ streptomycin and $25 \mu \mathrm{g} / \mathrm{ml}$ amphotericin B (all from VEC Technologies). Tumor cell invasion was performed by seeding $1.3 \times 10^{5}$ HUVECs (passage 7) into each well of a 12 -well plate pre-coated with $0.2 \%$ gelatin (Sigma) and cultured for 2 days to form a confluent monolayer. Mesothelial cells harvested from two-three mice were 
initially plated in 6-well plates and grown to confluency in DMEM medium supplemented with $10 \%$ fetal bovine serum in the presence of 100 units $/ \mathrm{ml}$ penicillin $\mathrm{G}$ and $10 \mu \mathrm{g} / \mathrm{ml}$ streptomycin. When confluent, the mesothelial cells were split into three equal aliquots ( $\sim 5 \times 10^{4}$ cells each) and plated to three wells of a 12-well plate and grown to confluence. For all invasion assays, MM1 cells were pre-stained with $2 \mu \mathrm{g} / \mathrm{ml}$ calcein $\mathrm{AM}$ (Invitrogen, USA) for $2 \mathrm{~h}$, rinsed once, and seeded at a density of $5 \times 10^{4}$ cells $/$ well over the monolayers. Tumor cells were left to invade the HUVEC monolayer for $24 \mathrm{~h}$ in MCDB-131 complete media containing $1 \%$ serum with or without addition of $1.5 \mu \mathrm{M}$ LPC. MM1 cells were plated on the mesothelial monolayers in $2 \%$ fetal bovine serumsupplemented DMEM medium in the presence of 100 units $/ \mathrm{ml}$ penicillin $\mathrm{G}$ and $10 \mu \mathrm{g} / \mathrm{ml}$ streptomycin with or without $1.5 \mu \mathrm{M}$ LPC $(5 \mu \mathrm{M}$ for the mesothelium cells) and invasion was allowed to proceed for $20 \mathrm{~h}$. The day after MM1 cell seeding, non-invaded tumor cells were removed by repeated five rinses of the HUVEC monolayer (three rinses for the mesothelial monolayers) with PBS (containing $\mathrm{Ca}^{2+}$ and $\mathrm{Mg}^{2+}$ ) followed by fixation with $10 \%$ buffered formalin. The number of tumor cells that penetrated the monolayer was photographed under a NIKON TiU inverted microscope using phase-contrast and fluorescence illumination in a minimum of five non-overlapping fields at $100 \mathrm{x}$ magnification. The fluorescent images were overlayed on top of the phase contrast images using the Elements BR software (version 3.1x) and the invaded MM1 cells showing the characteristic flattened morphology in the plane of focus underneath the monolayer were counted. For the invasion assay, LPC dissolved in chloroform was dried, re-dissolved in $1 \mathrm{mM}$ charcoal-stripped BSA in PBS and added immediately to the HUVEC or mesothelium monolayer and co-cultured with MM1 cells with or without the ATX inhibitors. The final BSA concentration was $30 \mu \mathrm{M}$.

\section{B16-F10 Murine Melanoma Metastasis Model}

All animal procedures were approved by the Institutional Animal Care and Use Committee at the University of Tennessee and the M.D. Anderson Cancer Center and were consistent with the Guide for the Care and Use of Laboratory Animals (National Institutes of Health publication 85-23, revised 1985). Eight-week-old female C57Bl/6 mice were injected with $5 \times 10^{4}$ cells/animal via tail veins and divided randomly into 4 groups. Each group then received selective ATX inhibitor (30 or $38 \mathrm{~b}$ ) or dual ATX and LPA receptor antagonist LPA-BP ${ }^{170}$ all at $0.5 \mathrm{mg} / \mathrm{kg} /$ injection or vehicle (PBS with $1 \%$ DMSO) via intraperitoneal injection 30 min after the B16-F10 injection and daily for an additional 10 days. Subsequently, animals in all groups were monitored for another 10 days without treatment. At day 21, all mice were sacrificed and lungs were harvested, inflated, and fixed with $10 \%$ formalin. The number of metastatic nodules on the lung surface was counted. The number of lung nodules was compared to vehicle treated group by one-way ANOVA followed by Newman-Keuls multiple comparison test and $\mathrm{p}<0.05$ was considered significant. 


\section{Chapter 4. Discovery of Non-Lipid LPA Analogues}

The lysophosphatidic acid receptor 2 ( $\mathrm{LPA}_{2}$, also known as endothelial differentiation gene 4, EDG4) is a G-protein coupled receptor (GPCR) activated by lysophosphatidic cid. LPA2 has been shown to be overexpressed in cells from many tumor types including breast, ${ }^{190}$ endometrial, ${ }^{191}$ ovarian, ${ }^{192}$ and gastric, ${ }^{193,194}$ to name a few. LPA 2 has also been shown to play a role in the development of airway inflammation and pathogenesis of asthma. ${ }^{195}$ Agonists at the $\mathrm{LPA}_{2}$ receptors have a proven therapeutic application of being used as a radioprotective agent, whereas antagonists of LPA2 receptors could be potential anticancer agents.

A synthesized analog of lysophosphatidic acid (LPA), octadecenyl thiophosphate (OTP) (Figure 4.1), showed strong radioprotective action by rescuing cells from apoptosis in mice irradiated with lethal doses of $\gamma$-irradiation. ${ }^{196}$ Experiments conducted with knockout mice indicate that the molecular target of OTP is the LPA 2 receptor. Unintended exposure to radiation by means of a nuclear accident, or explosion of a nuclear weapon can have devastating consequences on mankind. Octadecenyl thiophosphate (OTP) significantly reduces mortality following a lethal dose of $\mathrm{LD}_{80 / 30}$ radiation exposure in a mouse model of whole-body irradiation. OTP being a structurally similar analog of LPA, we intended to discover a more druglike, non-lipid compounds that would be equally efficacious in its pharmacological effects as well as have a benefit of being more druglike over OTP. We intended to study the structure activity relationships (SAR) and develop new agonists and antagonists of LPA.

Drug discovery is a multi-step process, with final products often taking more than 10 years to perfect. Finding better and faster methods for identifying promising drug candidates is the goal of many in academia and industry.Computational models of LPA GPCR were developed by Dr.Parrill and her group and that facilitated to identify receptor subtype selective non-lipid antagonists using in silico chemical searches of the NCI Developmental Therapeutics Database. Based on the hits that were obtained as a result of this virtual screening study, compounds from NCI were obtained and screened for their activity as antagonists One of them, NSC \# 16540, was initially found to have an impressive potency of 100nM as LPA2 antagonist. Hence, we decided to synthesize optically pure analogs of NSC \# 16540 depicted in Schemes 4.1 and 4.2. However, these compounds were tested and found to be inactive at the LPA receptor, We verified the data by reordering the original compound from NCI which was also found to be inactive. We then focused our efforts on obtaining compounds from the GRI compound library.

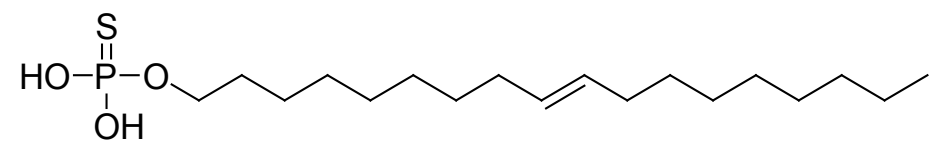

Figure 4.1. Octadecenyl Thiophosphate (OTP). 
<smiles>CCOC(=O)N1C(=O)c2ccccc2C1=O</smiles>

56<smiles>CC(=O)[C@H](N)CCC(=O)O</smiles>

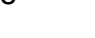
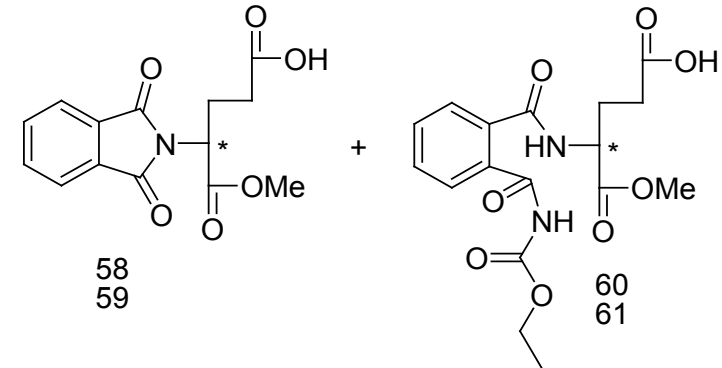

Scheme 4.1. Synthesis of Compounds 58 and 59.

Reagents and conditions: a; THF, $\mathrm{Et}_{3} \mathrm{~N}$, reflux, $16 \mathrm{hr}$.

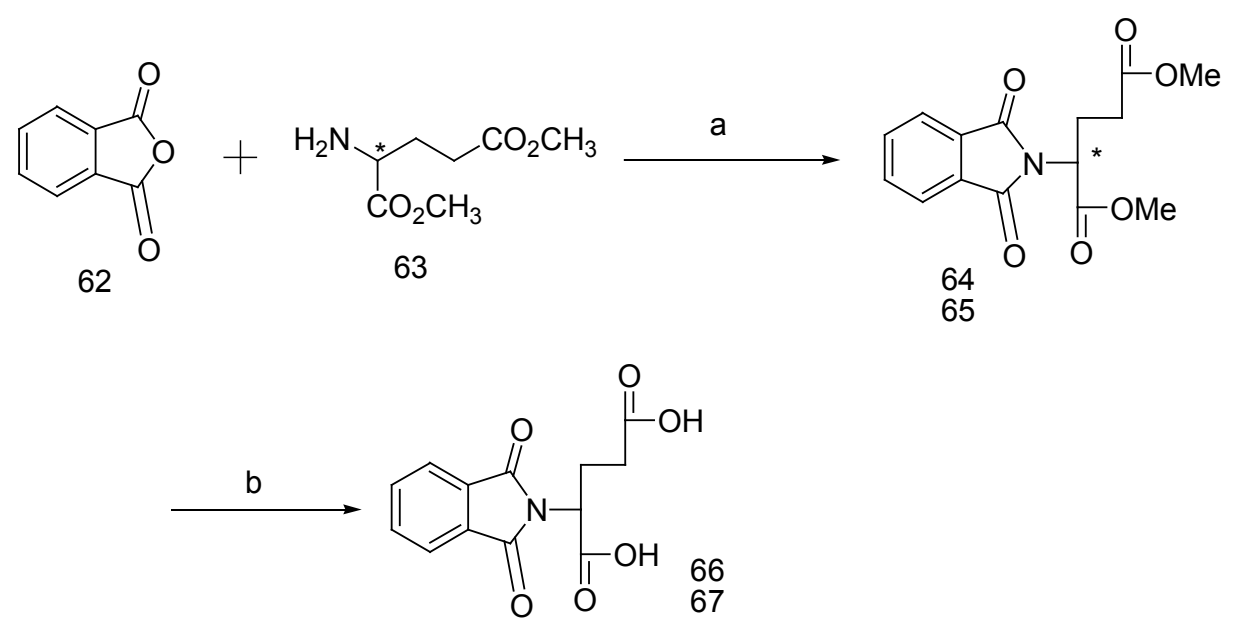

Scheme 4.2. Synthesis of Compounds 64, 65, 66 and 67.

Reagents and conditions: (a) Pyridine, reflux, 16h, 52\%; (b)(i) $\mathrm{LiOH}, \mathrm{THF} / \mathrm{MeOH} / \mathrm{H}_{2} \mathrm{O}$; (ii) $\mathrm{H}^{+}, 72 \%$. 


\section{GRI Compound Library}

A very beneficial, research resource was made available to us by collaboration with Dr. William Seibel from the University of Cincinnati Genome Research Institute: a worldclass compound library and associated high-throughput screening facilities and expertise. We had access to a drug-discovery compound library, high-throughput screening technology, and expertise to use the library, which was called the UC/GRI Compound Library. This library was carefully designed and maintained in order to provide the ability to screen biological targets for novel biochemical tools, probes and drug leads. The resource is larger and more targeted than most comparable resources, such as the NIH compound repository. The bulk of the compounds in the library are known, commercially-available molecules that are very well-characterized. Dr.Tigyi and Dr.Parrill's groups had identified a compound obtained from Hit2Lead, H2L5155239, to be an antagonist at LPA2 $\left(\mathrm{IC}_{50}=36.0 \mathrm{nM}\right)$ and a nonlipid target from the literature ${ }^{197}$ was reported to have an $\mathrm{IC}_{50}=0.017 \mu \mathrm{M}$. These two compound structures were sent to GRI for screening.

\section{Screening of GRI Library}

A similarity search was performed on the two compounds in Table 4.1. After the initial search we were provided with 87 structures from the similarity search results from which we selected 12 compounds based on their structural similarities to the compounds in Table 4.1. Compounds were supplied as $5 \mu \mathrm{L}$ of $10 \mathrm{mM}$ solutions in DMSO in 96-well plates. These 12 compounds were tested on the five LPA receptors (LPA $\left.{ }_{1-5}\right)$ and also against autotaxin in Dr.Tigyis lab. These compounds were also computationally modeled by Dr.Fells and it was noted that the presence of an electron withdrawing group on the naphthylamide was responsible for antagonist activity, whereas the absence of the electron withdrawing group rendered the compounds an agonist effect at the LPA receptors.Along with GRI 125093 (Table 4.2) there was another hit which was identified, GRI 948729. However, it was later established that GRI 948729 (Figure 4.2) was a false positive. The assay was a fluorescence based assay that utilized an indicator dye Fura2AM that monitored the calcium increase/decrease in the assay. Compound 948729 is a fluorescent compound and the fluorescence of the compound interfered with the indicator dye utilized in the assay. This was later confirmed using another calcium indicator, FLIPR $^{\circledR}$ calcium 5 assay kit. The fact that compound 948729 was a false positive was brought to light later and both compounds GRI125093 and 948729 were utilized as structural fingerprints for the next similarity search as shown in Figures 4.3, 4.4, and 4.5. Similarity searching looks for compounds that are most similar to the query compounds and each compound from the database is ranked depending on its similarities. The underlying principal is that structurally similar compounds usually show similar physicochemical properties and biological activities. ${ }^{198}$ Hence it is common to query small molecule database with a probe molecule that possess desirable pharmacological activity to find out other chemically similar database entries. ${ }^{199}$ The similarity search of the UC compounds database was carried out by Dr. Seibel and search parameters that reflected the structural organization of the molecule like the "structural fingerprints", e.g 
Table 4.1. Known LPA Antagonists.

\begin{tabular}{|c|c|c|c|}
\hline Reference & Structure & LPA2 & $\mathrm{LPA}_{1}$ and $\mathrm{LPA}_{3}$ \\
\hline $\begin{array}{l}\text { Bioorganic \& Medicinal } \\
\text { Chemistry Letters } 18 \\
\text { (2008) 1037-1041 }\end{array}$ & & $0.017 \mu \mathrm{M}$ & Not active $>50 \mu \mathrm{M}$ \\
\hline H2L 5155239 & & $\begin{array}{l}\text { Antagonist } \\
\mathrm{Ki}=17.0 \mathrm{nM} \\
\mathrm{IC}_{50}=36.0 \mathrm{nM}\end{array}$ & $\begin{array}{l}\mathrm{LPA}_{1} \text {-no effect } \\
\mathrm{LPA}_{3} \text {-antagonist } \\
22.7 \% \text { inhibition } \\
(30 \mu \mathrm{M})\end{array}$ \\
\hline
\end{tabular}

Table 4.2. GRI Compound 125093.

\begin{tabular}{|c|c|c|c|c|c|c|c|c|}
\hline Compound I.D. & Structure & RH & $\mathbf{L P A}_{1}$ & $\mathbf{L P A}_{2}$ & $\mathrm{LPA}_{3}$ & $\mathrm{LPA}_{4}$ & $\mathrm{LPA}_{5}$ & ATX \\
\hline GRI 125093 & & $\mathrm{NE}$ & $\begin{array}{l}\text { Agonist } \\
(61.0 \%)\end{array}$ & $\begin{array}{l}\text { Agonist } \\
(44.1 \%)\end{array}$ & $\begin{array}{l}\text { Agonist } \\
(66.4 \%)\end{array}$ & $\begin{array}{l}\text { Agonist } \\
(16.4 \%)\end{array}$ & $\begin{array}{l}\text { Agonist } \\
(35.4 \%)\end{array}$ & $\begin{array}{l}29.1 \pm \\
4.4 \% \text { inhibition } \\
(10 \mu \mathrm{M})\end{array}$ \\
\hline
\end{tabular}




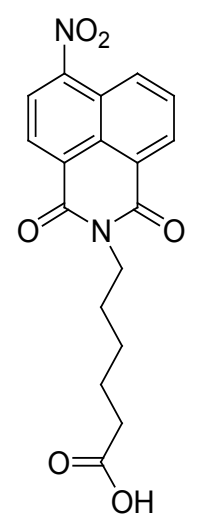

Figure 4.2. GRI 948729.

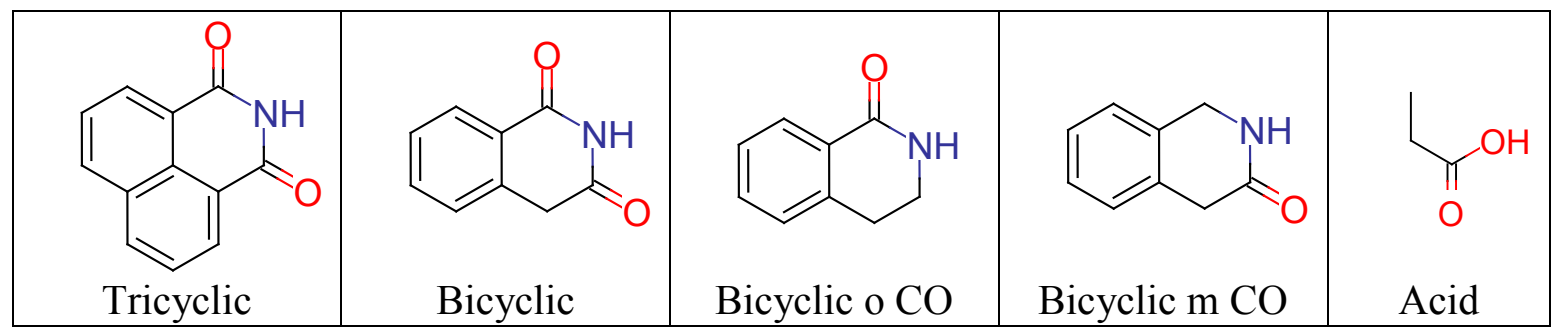

Figure 4.3. Structural Fingerprints for the Similarity Search. 


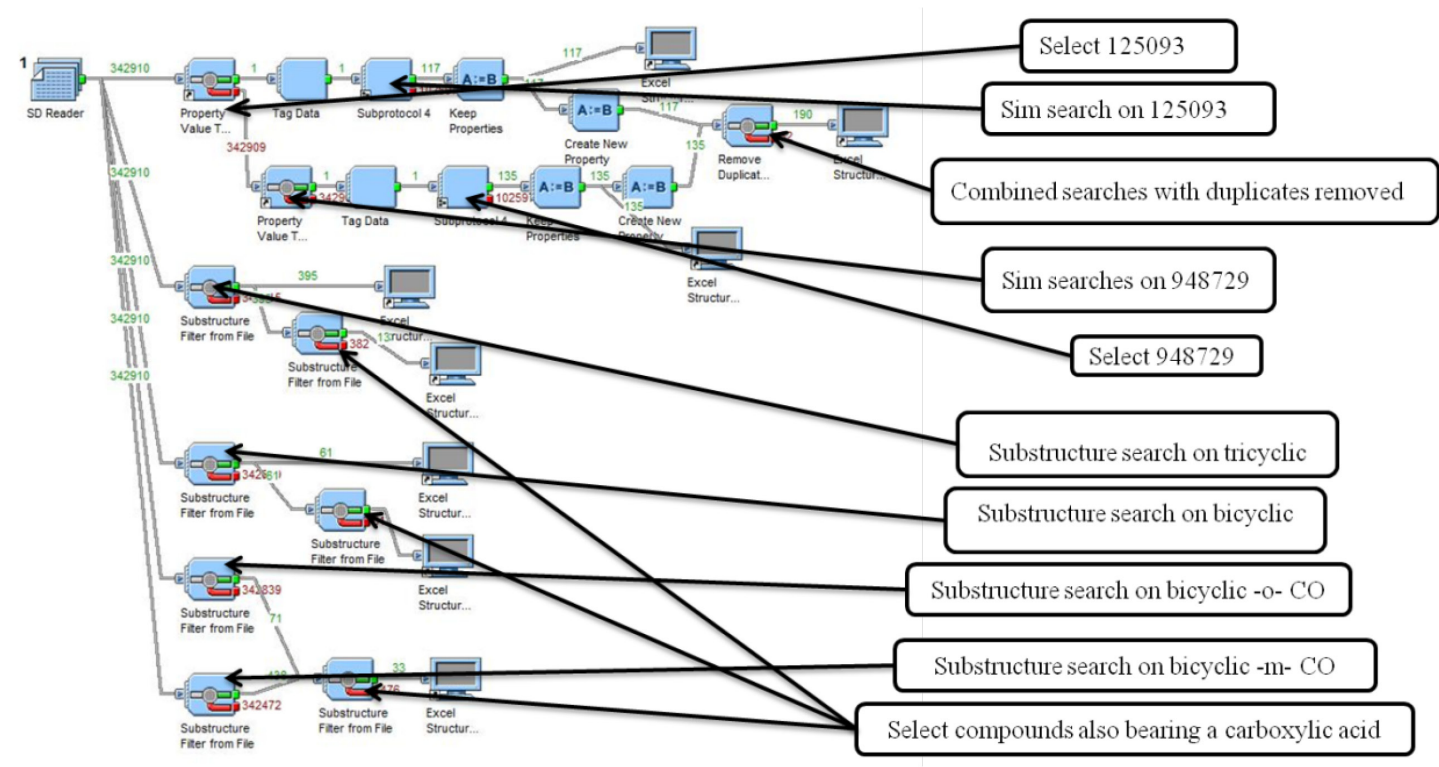

Figure 4.4. Similarity Search Protocol.

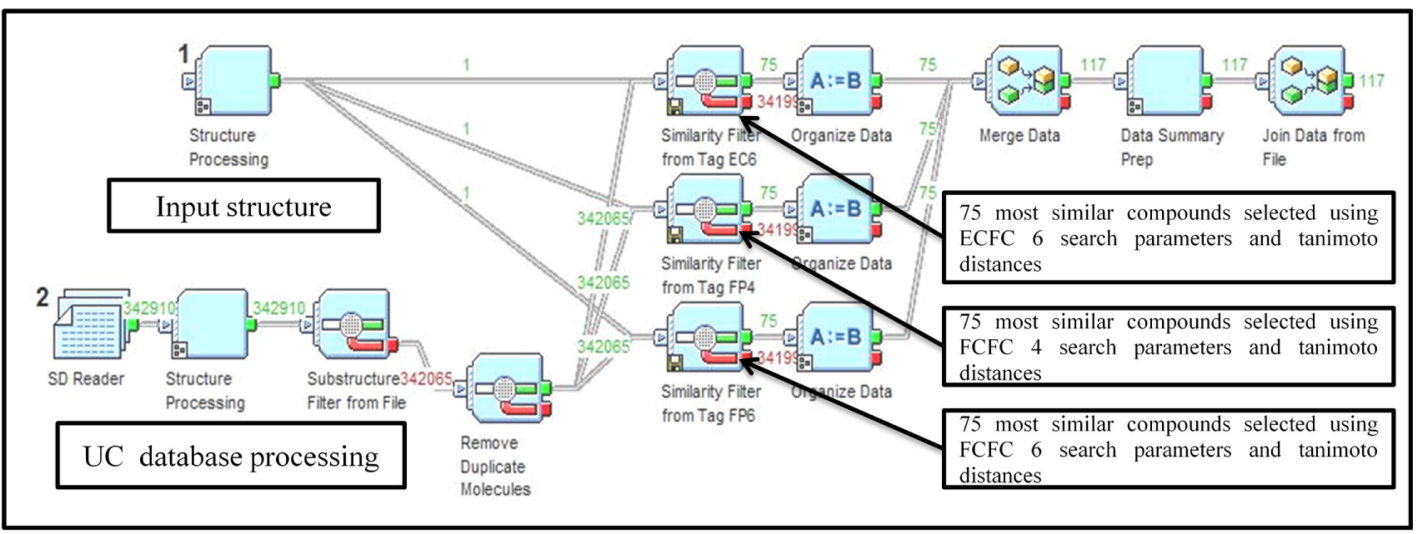

Figure 4.5. GRI Search Protocol.

ECFC6: extended connectivity fingerprints counts over 6 atoms; FCFP4: functional class connectivity fingerprints over 4 atoms; FCFP6: functional class connectivity fingerprints over 6 atoms. 
the existence of a fused tricyclic or bicyclic ring system ring system, presence of an acid moiety etc. these descriptors serve as independent variables in the modern quantitative structure activity relationships and the structural fingerprints used in the search method are showed in Figure 4.3. Tanimoto coefficients were also used in the similarity search and it provides a measure of similarity.

\section{Follow-Up Activities}

Similarity search was carried out on these compounds GRI 125093 and GRI 948729. 117 compounds were similar to these two hits and we selected 15 compounds from this list based on their structural similarities, and were screened at $1 \mu \mathrm{M}$ concentration. The Similarity Searches were conducted via the protocol, which is expanded to provide details of the search in Figure 4.5. With these pharmacological results we planned to synthesize compounds 73, 76 and 78. The synthesis of these compounds is shown in Schemes 4.3, 4.4, and 4.5.

However, these compounds, 73, 76 and 78 were not found to show any activity at the LPA receptors. Further screening of the GRI library lead to the discovery of compound GRI977143 depicted in Table 4.3. to be one of the better agonist at LPA receptor. We decided to make bioisoteric replacements at the carboxylate functional group of GRI 977143 and replace it with a phosphoric acid and thiophosphoric acid. The synthesis is depicted in Scheme 4.6.

Compound 82 was synthesized by the procedure depicted in literature ${ }^{200}$ and compounds $82,83,84,85$ and 86 were synthesized using the similar chemistries as before. In the biological assays these compounds failed to show any substantial activity.

\section{Experimental Section}

\section{Biology}

The Pharmacological assays were carried out in Dr.Tigyis Laboratory.The test compounds were obtained from UC Drug Discovery. The compounds supplied in $10 \mathrm{mM}$ concentrations. LPA receptor promoted intracellular $\mathrm{Ca}^{2+}$ mobilization was measured for LPA receptors in stably expressed cells as previously described. Briefly, cells were plated in 96-well plate and cultured overnight. The following day the $\mathrm{Ca}^{2+}$ assay was run using sing FLEXstation II (Molecular Devices, Sunnyvale, CA). The cells were loaded with fura-2. Changes in the intracellular $\mathrm{Ca}^{2+}$ concentration were then measured by determining the ratio of emitted light intensities at $520 \mathrm{~nm}$ in response to excitation at 340 and $380 \mathrm{~nm}$. The compounds were tested for agonist and antagonist activity. Each assay was run in quadruplicate. $\mathrm{IC}_{50}$ values were determined concentration curves for each compound. 

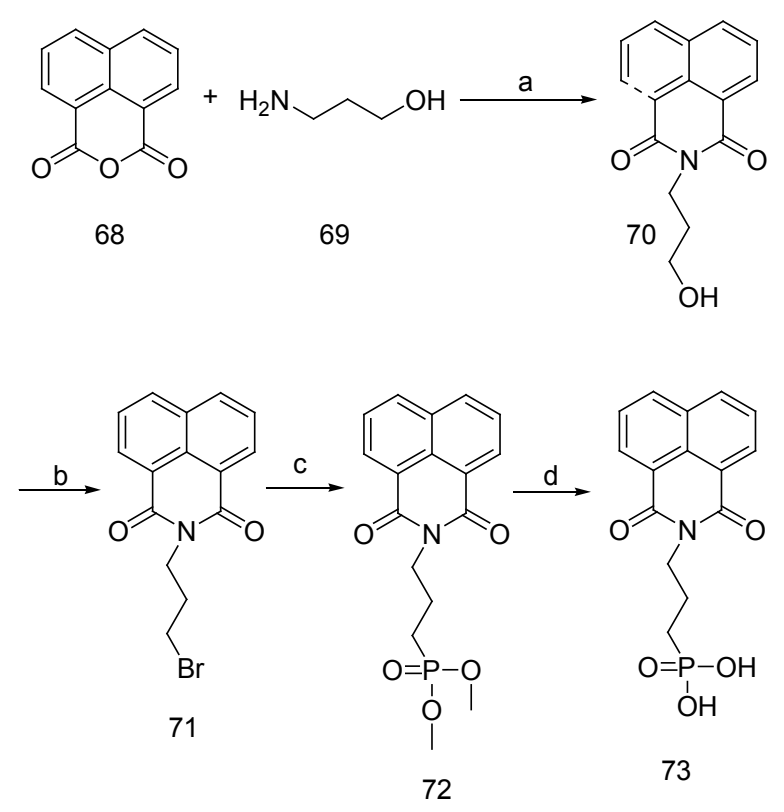

Scheme 4.3. Synthesis of Compound 73.

Reagents and conditions: a) Pyridine, reflux, 5h; b) $\mathrm{PBr}_{3}$,Ether $1 \mathrm{~h}$ c) Trimethylphosphite, reflux, $18 \mathrm{~h}$; d) i) $\mathrm{TMSBr}, \mathrm{CH}_{3} \mathrm{CN}$,reflux, 1h; ii) $\mathrm{MeOH}, 30 \mathrm{~min}$.
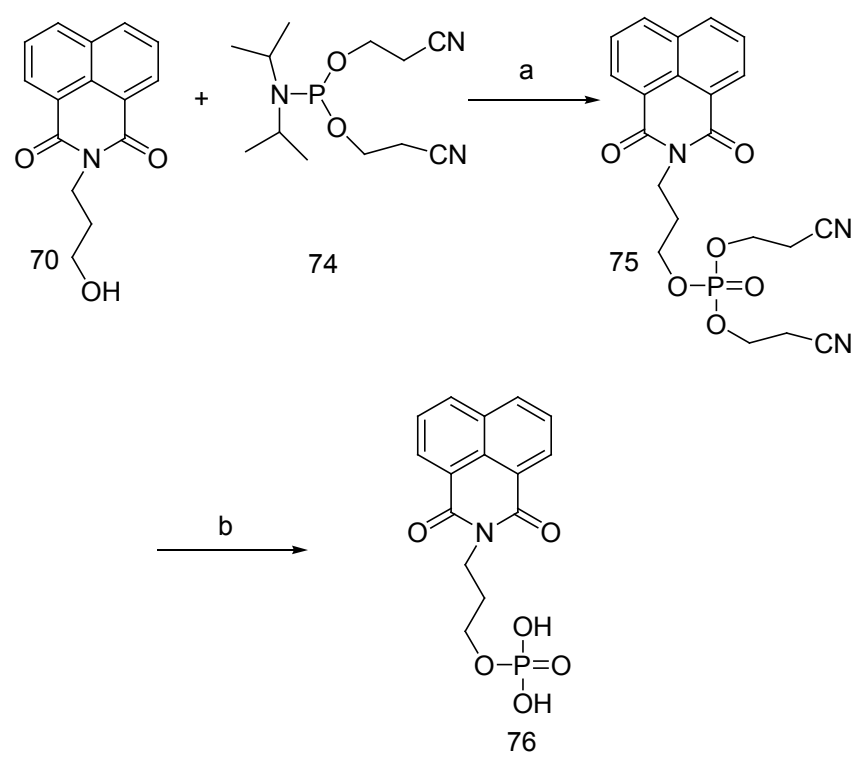

Scheme 4.4. Synthesis of Compound 76.

Reagents and conditions: (a)(i) bis(2-cyanoethyl)- $N, N$-diisopropylphosphoramidite, $1 H$ tetrazole, $\mathrm{CH}_{2} \mathrm{Cl}_{2}$, rt; (ii) $50 \% \mathrm{H}_{2} \mathrm{O}_{2}$; (b) (i) $\mathrm{KOH}, \mathrm{MeOH}$; (ii) dil $\mathrm{HCl}$. 

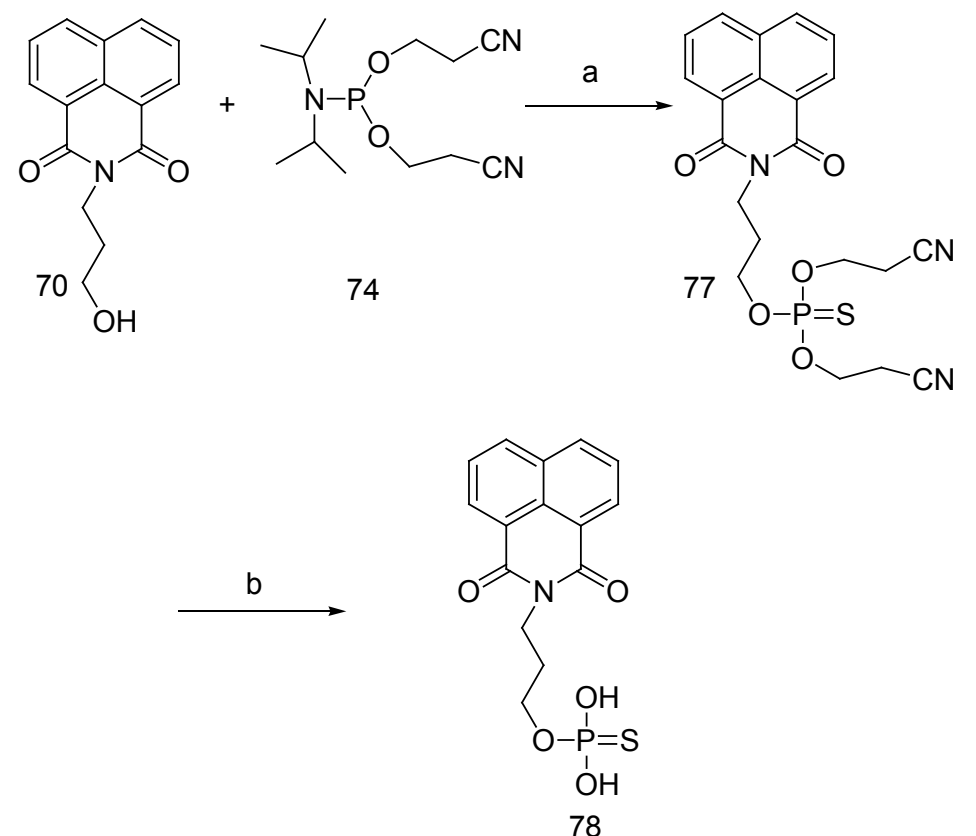

Scheme 4.5. Synthesis of Compound 78.

Reagents and conditions: (a (i) bis(2-cyanoethyl)- $N, N$-diisopropylphosphoramidite, $1 \mathrm{H}$-tetrazole, $\mathrm{CH}_{2} \mathrm{Cl}_{2}$, rt; (ii) sulfur, reflux, 2h; (b) (i) $\mathrm{KOH}, \mathrm{MeOH}$; (ii) dil $\mathrm{HCl}$.

Table 4.3. GRI 977143 Identified as a Lead Compound for LPA Agonist Activity.

\begin{tabular}{|c|c|c|c|}
\hline \multirow[b]{2}{*}{ Identification } & \multirow[b]{2}{*}{ Structure } & \multicolumn{2}{|c|}{ LPA $_{2}$ Activity } \\
\hline & & $\begin{array}{l}\mathrm{EC}_{50} \\
(\mu \mathrm{M})\end{array}$ & $\begin{array}{l}E_{\max } \\
(\%)\end{array}$ \\
\hline OTP & $\begin{array}{c}\mathrm{S} \\
\mathrm{HO}-\mathrm{P}_{\mathrm{I}}-\mathrm{O} \\
\mathrm{OH}\end{array}$ & 0.09 & 100 \\
\hline $\begin{array}{l}\text { GRI977143 } \\
\text { (Compound 2) }\end{array}$ & & 3.3 & 75 \\
\hline
\end{tabular}




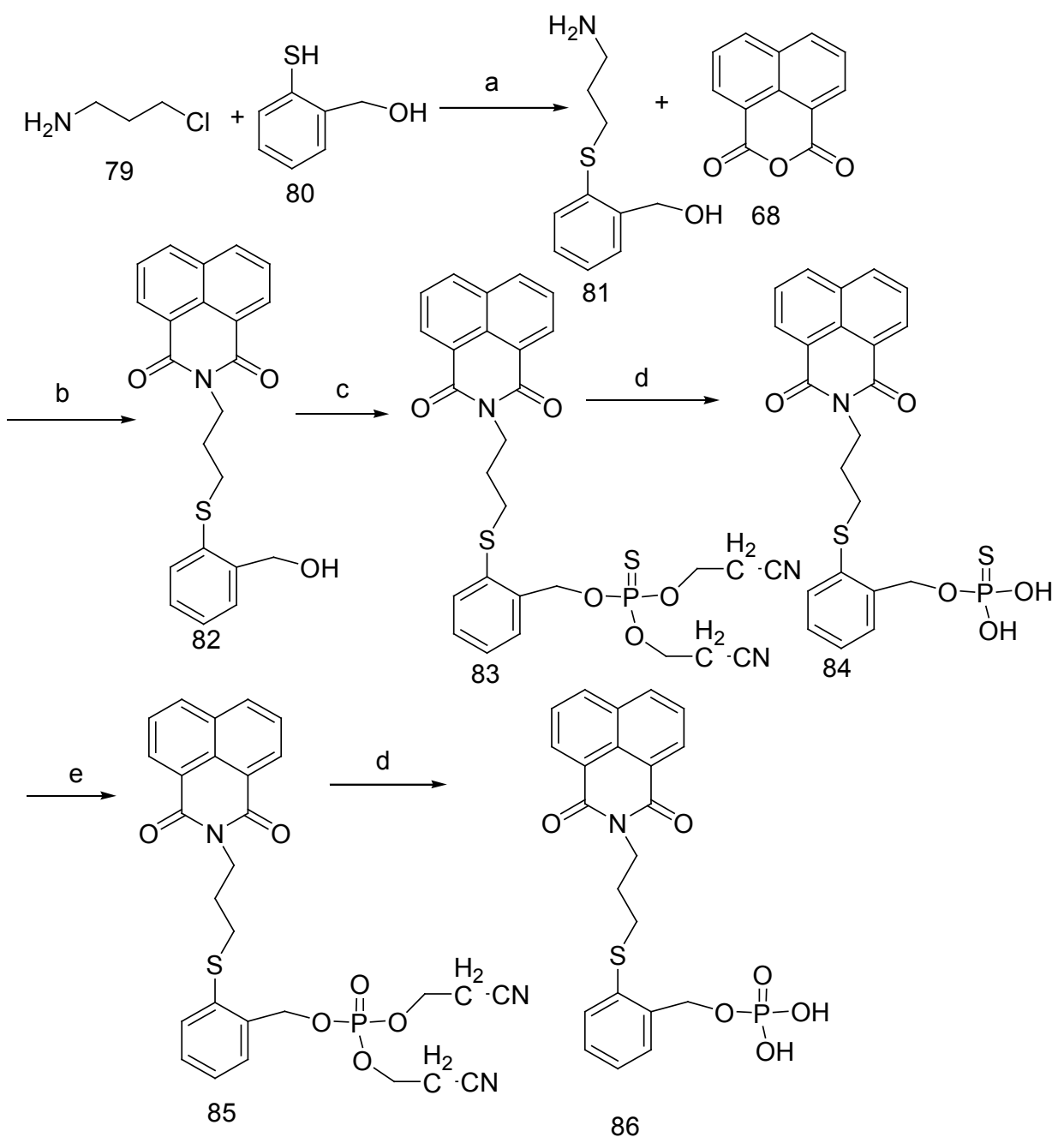

Scheme 4.6. Synthesis of Compound 84 and 86.

Reagents and conditions: a) $\mathrm{NaOH}, \mathrm{MeOH}$; b)Pyridine, Reflux c) (i) bis(2-cyanoethyl)$\mathrm{N}, \mathrm{N}$-diisopropylphosphoramidite, $1 \mathrm{H}$-tetrazole, $\mathrm{CH}_{2} \mathrm{Cl}_{2}$, rt; (ii) sulfur, reflux, $2 \mathrm{~h}$;

(d) (i) $\mathrm{KOH}, \mathrm{MeOH}$; (ii) dil $\mathrm{HCl}$; e) )(i) bis(2-cyanoethyl)-

$\mathrm{N}, \mathrm{N}$-diisopropylphosphoramidite, $1 \mathrm{H}$-tetrazole, $\mathrm{CH}_{2} \mathrm{Cl}_{2}$, rt; (ii) $50 \% \mathrm{H}_{2} \mathrm{O}_{2}$. 


\section{Chemistry}

All starting materials, reagents and solvents were obtained from commercial suppliers and were used without further purification. Reactions were performed under an inert atmosphere of argon, unless otherwise specified. Routine thin-layer chromatography (TLC) was performed on silica gel plates (Analtech, Inc., 250 microns). Flash chromatography was conducted on silica gel (Merck, grade 60, 230-400 mesh). ${ }^{1} \mathrm{H}$ NMR spectra were recorded on a Bruker ARX 300 spectrometer $(300 \mathrm{MHz})$ or Varian spectrometer $(400 \mathrm{MHz})$ using DMSO- $d_{6}$ and $\mathrm{CDCl}_{3}$ as solvents, and spectral data were consistent with assigned structures. Chemical shift values were reported as parts per million $(\delta)$, coupling constants $(J)$ are given in $\mathrm{Hz}$, and splitting patterns are designated as follows: s, singlet; d, doublet; t, triplet; q, quartet; $\mathrm{m}$, multiplet. Mass spectra were collected on a Brucker ESQUIRE electrospray/ion (ESI) trap instrument in the positive and negative modes.

Procedure for the synthesis of compounds 58, 59,60,61: Equimolar quantities of compound 56 and 57 were dissolved in anhydrous THF and 0.3 equivalents of triethylamine was added to the reaction mixture. The reaction was refluxed for $16 \mathrm{~h}$ to give compounds 58 and 59 respectively. Two side products, 60 and 61 were also charachterized from this reaction.

Compound 58: ${ }^{1} \mathrm{H}$ NMR $\left(300 \mathrm{MHz} \mathrm{CD}_{3} \mathrm{OD}\right) ; \delta=7.890(4 \mathrm{H}, \mathrm{m}) ; 4.958(1 \mathrm{H}, \mathrm{m}) ; 3.727$ $(3 \mathrm{H}, \mathrm{s}) ; 2.507-2.572(2 \mathrm{H}, \mathrm{m}) ; 2.446-2.333(2 \mathrm{H}, \mathrm{m})$; ESI MS M-H 289.8.

Compound 59: ${ }^{1} \mathrm{H}$ NMR $\left(300 \mathrm{MHz} \mathrm{CD}_{3} \mathrm{OD}\right) ; \delta=7.890(4 \mathrm{H}, \mathrm{m}) ; 4.958(1 \mathrm{H}, \mathrm{m}) ; 3.727$ $(3 \mathrm{H}, \mathrm{s}) ; 2.507-2.572(2 \mathrm{H}, \mathrm{m}) ; 2.446-2.333(2 \mathrm{H}, \mathrm{m})$; ESI MS M-H 289.8.

Compound 60: ${ }^{1} \mathrm{H}$ NMR (300 MHz CD $\left.{ }_{3} \mathrm{OD}\right) ; \delta=7-685-7.398$ (4H, m); 4.7-4.5(1H, m); $4.160(2 \mathrm{H}, \mathrm{m}) ; 3.737(3 \mathrm{H}, \mathrm{s}) ; 2.511(2 \mathrm{H}, \mathrm{m}) ; 2.3-2.0(2 \mathrm{H}, \mathrm{m}) ; 1.3(3 \mathrm{H}, \mathrm{t}) ; \mathrm{ESI} \mathrm{MS} \mathrm{M}+\mathrm{H}$ $381.1 \mathrm{M}+\mathrm{Na} 403.1$.

Compound 61: ${ }^{1} \mathrm{H}$ NMR $\left(300 \mathrm{MHz} \mathrm{CD}_{3} \mathrm{OD}\right) ; \delta=7-685-7.398(4 \mathrm{H}, \mathrm{m}) ; 4.7-4.5(1 \mathrm{H}, \mathrm{m})$; $4.160(2 \mathrm{H}, \mathrm{m}) ; 3.737(3 \mathrm{H}, \mathrm{s}) ; 2.511(2 \mathrm{H}, \mathrm{m}) ; 2.3-2.0(2 \mathrm{H}, \mathrm{m}) ; 1.3(3 \mathrm{H}, \mathrm{t}) ; \mathrm{ESI} \mathrm{MS} \mathrm{M}+\mathrm{H}$ $381.1 \mathrm{M}+\mathrm{Na} 403.1$.

Synthesis of 64 and 65: Equimolar amounts of L-Glutamic acid and phthalic anhydride were heated under reflux in anhydrous pyridine for $24 \mathrm{hrs}$ (under argon atmosphere). The pyridine was evaporated and the reaction mixture was extracted with chloroform and washed first with $1 \mathrm{~N} \mathrm{HCl}$ and then with $1 \mathrm{~N} \mathrm{NaOH}$ solution. The organic layer was dried over anhydrous sodium sulfate and the solvent was removed under pressure. The residue was purified by column chromatography on silica gel (eluted with Hexanes/Ethylacetate $(1.5: 1)$ to give Phthaloylglutamic dimethyl ester.

Compound 64 :Phthaloylglutamic dimethyl ester.(52.98\% yield) ${ }^{1} \mathrm{H}$ NMR $(300 \mathrm{MHz}$ $\left.\mathrm{CDCl}_{3}\right) ; \delta 2.38-2.41(2 \mathrm{H}, \mathrm{m}), 2.45-2.67(2 \mathrm{H}, \mathrm{m}), 3.623(3 \mathrm{H}, \mathrm{s}), 3.74(3 \mathrm{H}, \mathrm{s}), 4.92-4.95$ $(1 \mathrm{H}, \mathrm{q}), 7.74-7.78(2 \mathrm{H}, \mathrm{m}), 7.86-7.89(2 \mathrm{H}, \mathrm{m})$. 
Compound 65: Phthaloylglutamic dimethyl ester.(44.025\% yield) ${ }^{1} \mathrm{H}$ NMR $(300 \mathrm{MHz}$ $\left.\mathrm{CDCl}_{3}\right) ; \delta 2.40-2.51(2 \mathrm{H}, \mathrm{m}), 2.53-2.69(2 \mathrm{H}, \mathrm{m}), 3.628(3 \mathrm{H}, \mathrm{s}), 3.754(3 \mathrm{H}, \mathrm{s}), 4.91-4.96$ $(1 \mathrm{H}, \mathrm{q}), 7.73-7.78(2 \mathrm{H}, \mathrm{m}), 7.793-7.796(2 \mathrm{H}, \mathrm{m})$.

Synthesis of D and L Phthaloyl Glutamic acid (66,67): To L(or D)-Phthaloylglutamic dimethyl ester, add THF at $0^{\circ} \mathrm{C}$ and then add $1 \mathrm{~N} \mathrm{LiOH}$ dropwise, under argon atmosphere. Stir for $30 \mathrm{~min}$. Solvent was evaporated and extracted with ethylacetate. The Ethylacetate layer was washed with $1 \mathrm{~N} \mathrm{HCl}\left(\mathrm{P}^{\mathrm{H}} 1-2\right)$. The Ethyl acetate was then evaporated in vacuo to give product.

Compound 66: (54.72\% yield) ${ }^{1} \mathrm{H}$ NMR $\left(300 \mathrm{MHz} \mathrm{CDCl}_{3}\right) ; \delta$ 2.07-2.10 $(2 \mathrm{H}, \mathrm{m})$, 2.38-2.51(2H, m), 4.34-4.41(1H, q), 7.43-7.62 (2H, m), 7.77-8.55(2H, m); $12.55(2 \mathrm{H}, \mathrm{s})$ Compound 67: (72.42\% yield) ${ }^{1} \mathrm{H}$ NMR $\left(300 \mathrm{MHz} \mathrm{CDCl}_{3}\right) ; \delta 2.07-2.10(2 \mathrm{H}, \mathrm{m})$, 2.38-2.51(2H, m), 4.34-4.41(1H, q), 7.43-7.62 (2H, m), 7.77-8.55(2H, m); $12.55(2 \mathrm{H}, \mathrm{s})$.

Procedure for the synthesis of 70 and 82: Equimolar quantities of the anhydride and the primary amine were refluxed in pyridine for four hours to give pure products. No further purification was needed.

Compound 70: ${ }^{1} \mathrm{H}$ NMR $\left(300 \mathrm{MHz} \mathrm{CDCl}_{3}\right) ; \delta=8.634-8.613(2 \mathrm{H}, \mathrm{d}, \mathrm{J}=6.3 \mathrm{~Hz}) ; 8.258$ $8.233(2 \mathrm{H}, \mathrm{d}, \mathrm{J}=7.5 \mathrm{~Hz}) ; 7.779(2 \mathrm{H}, \mathrm{t}) ; 4.362(2 \mathrm{H}, \mathrm{t}) ; 3.59(2 \mathrm{H}, \mathrm{t}) ; 3.2-3.1(1 \mathrm{H}, \mathrm{s}) ; 2.002$ $(2 \mathrm{H}, \mathrm{p})$.

Synthesis of 72: Compound 70 was first converted to its bromide derivative by the addition of 0.3 Equivalents of $\mathrm{PBr}_{3}$, and using diethethyl ether as solvent, the reaction was quenched by the addition of water at $0^{\circ} \mathrm{C}$. the compound was extracted and dried over magnesium sulfate. The dry bromide derivative was then taken into a flask and trimethylphosphite was added to it (large excess) and refluxed for $18 \mathrm{~h}$ to obtain compound 72: ${ }^{1} \mathrm{H}$ NMR $\left(300 \mathrm{MHz} \mathrm{CDCl}_{3}\right) ; \delta=8.634-8.613(2 \mathrm{H}, \mathrm{d}, \mathrm{J}=6.3 \mathrm{~Hz})$; 8.258-8.233 (2H, d, J = 7.5Hz); $7.779(2 \mathrm{H}, \mathrm{t}) ; 4.348(2 \mathrm{H}, \mathrm{t}) ; 4.243(2 \mathrm{H}, \mathrm{t}) ; 3.79(6 \mathrm{H}, \mathrm{d}, \mathrm{J}$ $=12) ; 2.177(2 \mathrm{H}, \mathrm{p})$.

Synthesis of 73: To a suspension of phosphonate derivative 72 (1 equiv) in anhydrous acetonitrile, TMSBr (2.5 equiv) was added and the reaction mixture was refluxed for $1 \mathrm{~h}$. The acetonitrile was then evaporated under reduced pressure and $\mathrm{MeOH}$ was added to the residue and stirred for 30 minutes at room temperature. The desired product was obtained in good yield after filtration of $\mathrm{MeOH}$ solution as a white solid. ${ }^{1} \mathrm{H}$ NMR $(300 \mathrm{MHz}$ $\mathrm{dmso}) ; \delta=8.634-8.613(2 \mathrm{H}, \mathrm{d}, \mathrm{J}=6.3 \mathrm{~Hz}) ; 8.258-8.233(2 \mathrm{H}, \mathrm{d}, \mathrm{J}=7.5 \mathrm{~Hz}) ; 7.779(2 \mathrm{H}, \mathrm{t})$; $4.348(2 \mathrm{H}, \mathrm{t}) ; 4.243(2 \mathrm{H}, \mathrm{t}) ; 3.325(2 \mathrm{H}, \mathrm{s}) ; 2.177(2 \mathrm{H}, \mathrm{p})$.

General procedure for 76 and $86: 1 H$-tetrazole ( $2.134 \mathrm{mmol}$ ) and bis(2-cyanoethyl) $N, N$-diisopropylphosphoramidite $(1.067 \mathrm{mmol})$ were added to a solution of compound 70 or $82(0.534 \mathrm{mmol})$ in $\mathrm{CH}_{2} \mathrm{Cl}_{2}$ and the mixture was stirred for $1 \mathrm{~h}$ followed by addition of hydrogen peroxide $(0.12 \mathrm{ml})$ to give compound 77 and 85 respectively. Compound 75 or 85 (1 equiv) was dissolved in methanol and $1 \mathrm{~N}$ methanolic $\mathrm{KOH}$ (1equiv) was added to the reaction mixture. The completion of the reaction was monitored by TLC. The 
methanol was evaporated and $1 \mathrm{~N} \mathrm{HCl}$ was added and the compound was extracted with $\mathrm{CHCl}_{3}$. Purification of the crude residue by coloumn chromatography (30:1

$\mathrm{CHCl}_{3}: \mathrm{MeOH}$ ) gave desired compounds 76 and 86 respectively.

Compound 76: ${ }^{1} \mathrm{H}$ NMR $\left(300 \mathrm{MHz} \mathrm{CD}_{3} \mathrm{OD}\right) ; \delta=8.431-8.407(2 \mathrm{H}, \mathrm{d}, \mathrm{J}=7.2 \mathrm{~Hz})$;

8.241-8.214 (2H, d, J = 8.1Hz); $7.881(1 \mathrm{H}, \mathrm{s}) ; 7.708(2 \mathrm{H}, \mathrm{t}) ; 4.221(2 \mathrm{H}, \mathrm{t}) ; 4.070(2 \mathrm{H}, \mathrm{t})$; $2.033(2 \mathrm{H}, \mathrm{p})$.

Procedure for 78 and $84: 1 H$-tetrazole ( $2.134 \mathrm{mmol})$ and bis(2-cyanoethyl) $\mathrm{N}, \mathrm{N}$ diisopropylphosphoramidite $(1.067 \mathrm{mmol})$ were added to a solution of compound 70 or 82 $(0.534 \mathrm{mmol})$ in $\mathrm{CH}_{2} \mathrm{Cl}_{2}$ and the mixture was stirred for $1 \mathrm{~h}$ followed by addition of sulfur (4Eq)and the reaction mixture was refluxed for $2 \mathrm{hr}$ to give compound 77 and 83 respectively. Compound 77 or 83 (1 equiv) was dissolved in methanol and $1 \mathrm{~N}$ methanolic $\mathrm{KOH}$ (1equiv) was added to the reaction mixture. The completion of the reaction was monitored by TLC. The methanol was evaporated and $1 \mathrm{~N} \mathrm{HCl}$ was added and the compound was extracted with $\mathrm{CHCl}_{3}$. Purification of the crude residue by coloumn chromatography $\left(30: 1 \mathrm{CHCl}_{3}: \mathrm{MeOH}\right)$ gave desired compounds 76 and 86 respectively.

Compound 77: ${ }^{1} \mathrm{H}$ NMR $\left(300 \mathrm{MHz} \mathrm{CDCl}_{3}\right) ; \delta=8.634-8.613(2 \mathrm{H}, \mathrm{d}, \mathrm{J}=6.3 \mathrm{~Hz})$; $8.258-8.233(2 \mathrm{H}, \mathrm{d}, \mathrm{J}=7.5 \mathrm{~Hz}) ; 7.779(2 \mathrm{H}, \mathrm{t}) ; 4.348$ (8H, overlapping protons); 4.243 $(2 \mathrm{H}, \mathrm{t}) ; 2.805(4 \mathrm{H}, \mathrm{t}) ; 2.173(2 \mathrm{H}, \mathrm{p})$.

Compound 78: ${ }^{1} \mathrm{H}$ NMR $\left(300 \mathrm{MHz} \mathrm{CD}_{3} \mathrm{OD}\right) ; \delta=8.431-8.407(2 \mathrm{H}, \mathrm{d}, \mathrm{J}=7.2 \mathrm{~Hz})$; 8.241-8.214 (2H, d, J = 8.1Hz); $7.881(1 \mathrm{H}, \mathrm{s}) ; 7.708(2 \mathrm{H}, \mathrm{t}) ; 4.221(2 \mathrm{H}, \mathrm{t}) ; 4.070(2 \mathrm{H}, \mathrm{t})$; $2.033(2 \mathrm{H}, \mathrm{p})$.

Compound 82: ${ }^{1} \mathrm{H}$ NMR $\left(400 \mathrm{MHz} \mathrm{CDCl}_{3}\right) ; \delta=8.573-8.556(2 \mathrm{H}, \mathrm{d}) ; 8.206-8.185(2 \mathrm{H}$, d); $7.732(2 \mathrm{H}, \mathrm{t}) ; 7.433(2 \mathrm{H}, \mathrm{d}) ; 7.203(2 \mathrm{H}, \mathrm{m}) 4.833(2 \mathrm{H}, \mathrm{s}) ; 4.297(2 \mathrm{H}, \mathrm{t}) ; 3.040(2 \mathrm{H}, \mathrm{t})$; $2.047(2 \mathrm{H}, \mathrm{p})$.

Compound 84: ${ }^{1} \mathrm{H}$ NMR (400 MHz CD $\left.3 \mathrm{OD}\right) ; \delta=8.432(4 \mathrm{H}, \mathrm{m}) ; 7.732(2 \mathrm{H}, \mathrm{t})$; 7.470-7.219 (4H,m); 4.921-4.905 (2H, d); $4.185(2 \mathrm{H}, \mathrm{t}) ; 3.040(2 \mathrm{H}, \mathrm{t}) ; 1.945(2 \mathrm{H}, \mathrm{p})$.

Compound 86: ${ }^{1} \mathrm{H}$ NMR (400 MHz CD $\left.3 \mathrm{OD}\right) ; \delta=8.546-8.390(4 \mathrm{H}, \mathrm{m}) ; 7.732(2 \mathrm{H}, \mathrm{t})$; 7.470-7.219 (4H,m); 4.921-4.905 (2H, d); $4.185(2 \mathrm{H}, \mathrm{t}) ; 3.040(2 \mathrm{H}, \mathrm{t}) ; 1.945(2 \mathrm{H}, \mathrm{p})$.

\section{Conclusion}

Drug discovery is a multi-step process, with final products often taking more than a decade to perfect. Finding better and faster methods for identifying promising drug candidates is the goal of many in academia and industry. A rapid screening method, such as the library provided by the GRI, a high-throughput screening system, adds to the drugdiscovery arsenal. Once identified, potentially useful compounds, or "drug candidates," are then further tested in specific disease models, licensed or sold to biotech or pharmaceutical companies for continued development. This research endeavour has 
enabled us to identify lead molecules of the LPA receptors. The screening of these compounds also unfolded some interesting structure activity relationships. Although I was not able to make potent compounds at the LPA receptors, I believe further optimization of the medicinal chemistry targets will yield better, non lipid analogs of LPA. 


\section{Chapter 5. Discussion of Dissertation}

The first two projects discussed in this dissertation deal with the development of autotaxin inhibitors. These projects play a vital role in the need for continuing research to better understand the pharmacology of cancer and aim at designing newer antineoplastic drugs that would improve the survival and outcomes in cancer patients. The first two projects I have worked on both involved synthesis of autotaxin inhibitors but both focused on different core structures. The first project I worked on focused on the synthesis of stereoisomers of 3-CCPA, which was previously shown to have potent autotaxin inhibitory effect. My second project involved the design of novel benzyl and naphthalene-methyl phosphonic acid inhibitors as autotaxin inhibitors and we were successful in identifying a very potent and promising ATX inhibitor. The third project involved identifying LPA2 analogs by screening the GRI compound library and undertaking the development of non-lipid LPA analogs. The purpose of this chapter is to offer a look into the crucial aspects of each project and to discuss potential future actions that can keep these projects successful.

\section{3-CCPA Project}

This project was discussed in Chapter 2 of this dissertation. It dealt with the synthesis of stereoisomers of 3-CCPA to further understand the therapeutic utility of racemic 3CCPA. 3-carba analogs of CPA lack significant agonist activity at LPA receptors yet are potent inhibitors of ATX activity, LPA production, and A2058 melanoma cell invasion in vitro and B16F10 melanoma cell metastasis in vivo. We found that both the $\mathrm{R}$ and the $\mathrm{S}$ stereoisomer inhibited ATX in vitro as well as the B16F10 melanoma metastasis in vivo with equal efficacy. The two isomers failed to show any significant stereospecificity. However, at the LPA 5 GPCR, the S-stereoisomer (S-3-CCPA) showed significantly higher efficacy. This was the first study indicating the stereospecific agonist action on $\mathrm{LPA}_{5}$ receptors.

\section{Benzyl and Naphthalene-Methyl Phosphonic Acid Inhibitors of Autotaxin Project}

This project was discussed in Chapter 3 of this dissertation. The ATX-LPA-LPA receptor axis is a potential therapeutic target for the management of cancer metastases and therapeutic resistance. Ferry and colleagues described a ATX inhibitor 4-tetradecanoylaminobenzyl phosphonic acid (S32826) that possessed nanomolar activity in vitro. ${ }^{177}$ Unfortunately, S32826 failed to show activity in cellular and in vivo systems. We hypothesized that hydrolysis of the amide bond present in S32826 could be the reason for its instability and thus lack of activity in cellular systems. To overcome the presumed lack of stability of S32826, we designed analogs that were expected to be more stable than the parent compound and we were successful in generating a panel of analogs that inhibit ATX with potencies comparable to that of S32826. These stabilized analogs inhibit ATX via a mixed-mode mechanism in vitro without any effect on the related 
lysophospholipid phosphodiesterases, NPP6 and NPP7 or on LPA receptors (LPAR). Two of these compounds, 30 and 38b inhibited ATX-dependent invasion of rat MM1 hepatoma cells of mesothelial cell and human umbilical cord vascular endothelialcell (HUVEC) monolayers in vitro. In addition, 30 and $38 \mathrm{~b}$ showed a profound reduction in lung foci in vivo using the B16-F10 syngeneic melanoma metastasis model in C57BL/6 mice. Based on these results compounds 30 and $38 \mathrm{~b}$ represent promising leads for further synthetic improvement and also provide proof of principle that ATX inhibitors offer therapeutic utility in the control of cancer metastasis in vivo. Subsequently, we generated analogs of compounds 22 and $38 \mathrm{~b}$ and examined their inhibition of ATX. The modifications were either in the aliphatic chain, the linker of the phosphate moiety, or on the phosphate moiety itself.

The most effective analogs based on the single $10-\mu \mathrm{M}$ dose inhibition assay were extensively characterized to determine $\mathrm{IC}_{50}, \mathrm{~K}_{\mathrm{i}}$, and $\mathrm{K}_{\mathrm{i}}$ ' values against ATX-mediated hydrolysis of FS-3. Replacement of the amide with a sulfonamide (12) reduced potency. Introduction of an ether (18) or alkene (26) connecting the hydrocarbon chain to the benzyl ring decreased the potency compared to the simple aliphatic chain. Linkage of the phosphate moiety in compound 53 through a methyl phosphonate reduced efficacy. However, converting the phosphate to a thiophosphate (55) in this scaffold increased efficacy at $10 \mu \mathrm{M}$ 5.6-fold. $\alpha$-Halogenation of the linker methyl group generally decreased potency of compounds 49,50 , and 51 relative to compound 30 . Insertion of a $\alpha$-hydroxyl group into the linker methylene increased the potency of this analog but it did not surpass that of compound 30 .

Modification of the side chain at position 6 of the naphthalene-2yl-methyl phosphonic acid scaffold showed that the 10-carbon side chain was more effective than the 11 carbon chain and that incorporation of an alkene had differential effects depending on the chain length (decreased efficacy of compound 38a relative to $42 \mathrm{a}$, but increased efficacy of $38 \mathrm{~b}$ over $42 \mathrm{~b}$ ). Analysis of the seven analogs showed that compound 30 in the benzyl phosphonic acid series and compound $38 \mathrm{~b}$ in the naphthalene-methyl phosphonic acids were the most potent analogs with respect to ATX inhibition. Future research should involve synthesis of analogs of compound 30 by varying the carbon chain lengths and designing more molecules so as to provide better insight in the structure activity relationship, unearthing a lead molecule in the quest for the discovery of anti cancer drugs.

\section{Non-Lipid LPA2 Analogs Project}

This project was discussed in Chapter 4 of this dissertation. This project involved various steps like in-silico screening of compounds, selecting and testing the compounds from the GRI library based on the structural similarities, obtaing a hit in pharmacological assays and developing the hit into a lead. Drug discovery is a multi-step process. Finding better and faster methods for identifying promising drug candidates is the goal of many in academia and industry. A rapid screening method, such as the library provided by the GRI, a high-throughput screening system, adds to the drug-discovery arsenal. Once 
identified, potentially useful compounds, or "drug candidates," are then further tested in specific disease models, licensed or sold to biotech or pharmaceutical companies for continued development This research endeavour has enabled us to identify lead molecules of the LPA receptors. The screening of these compounds also unfolded some interesting structure activity relationships. Although I was not able to make potent compounds at the LPA receptors, I believe further optimization of the medicinal chemistry targets will yield better, non lipid analogs of LPA.

\section{Final Thoughts}

During my tenure at graduate school, I have had the pleasure of being able to conduct cutting edge research in an area that shows a clear need for new development. Although my training has been as a synthetic medicinal chemist, my educational experience has allowed me to become a well-rounded scientist.

Medicinal chemistry is an interdisciplinary science. It utilizes knowledge from a variety of scientific fields in order to effectively create a well-rounded scientist. Working as a medicinal chemist involves working in an interdisciplinary environment where collaboration is the key to success. A medicinal chemist is a person who can bridge some of the gaps between chemistry and biology. This ability makes a well-trained medicinal chemist an invaluable asset to any interdisciplinary research team. The projects that I have worked on during my time in graduate school have been projects that have afforded me ample hands-on experience in the chemistry laboratory. I have had the opportunity to expand my knowledge base on a variety of different synthetic techniques. In addition to my expanded chemistry knowledge, I have been able to grow my knowledge on the pharmacological significance for these projects. These projects allowed me to build up a significant knowledge base in the understanding of LPA and its pharmacological significance. The ability to work on projects that required me to expand my knowledge has really benefited me in my quest to become a well-rounded scientist. It is my goal to continue to grow my knowledge base for each project that I undertake during my professional career. 


\section{List of References}

1. Parrill, A. L. Lysophospholipid interactions with protein targets. Biochim. Biophys. Acta 2008, 1781, 540-546.

2. Tigyi, G.; Miledi, R. Lysophosphatidates bound to serum albumin activate membrane currents in Xenopus oocytes and neurite retraction in PC12 pheochromocytoma cells. J. Biol. Chem. 1992, 267, 21360-21367.

3. $\quad$ Baker, D. L.; Morrison, P.; Miller, B.; Riely, C. A.; Tolley, B.; Westermann, A. M.; Bonfrer, J. M.; Bais, E.; Moolenaar, W. H.; Tigyi, G. Plasma lysophosphatidic acid concentration and ovarian cancer. JAMA 2002, 287, 3081-3082.

4. Zhao, Y.; Natarajan, V. Lysophosphatidic acid signaling in airway epithelium: role in airway inflammation and remodeling. Cell Signal. 2009, 21, 367-377.

5. Hama, K.; Bandoh, K.; Kakehi, Y.; Aoki, J.; Arai, H. Lysophosphatidic acid (LPA) receptors are activated differentially by biological fluids: possible role of LPAbinding proteins in activation of LPA receptors. FEBS Lett. 2002, 523, 187-192.

6. Saulnier-Blache, J. S. [Lysophosphatidic acid: a "bioactive" phospholipid]. Med. Sci. (Paris) 2004, 20, 799-803.

7. Murakami-Murofushi, K.; Uchiyama, A.; Fujiwara, Y.; Kobayashi, T.; Kobayashi, S.; Mukai, M.; Murofushi, H.; Tigyi, G. Biological functions of a novel lipid mediator, cyclic phosphatidic acid. Biochim. Biophys. Acta 2002, 1582, 1-7.

8. Tsukahara, T.; Tsukahara, R.; Fujiwara, Y.; Yue, J.; Cheng, Y.; Guo, H.; Bolen, A.; Zhang, C.; Balazs, L.; Re, F.; Du, G.; Frohman, M. A.; Baker, D. L.; Parrill, A. L.; Uchiyama, A.; Kobayashi, T.; Murakami-Murofushi, K.; Tigyi, G. Phospholipase D2-dependent inhibition of the nuclear hormone receptor PPARgamma by cyclic phosphatidic acid. Mol. Cell 2010, 39, 421-432.

9. Baker, D. L.; Fujiwara, Y.; Pigg, K. R.; Tsukahara, R.; Kobayashi, S.; Murofushi, H.; Uchiyama, A.; Murakami-Murofushi, K.; Koh, E.; Bandle, R. W.; Byun, H. S.; Bittman, R.; Fan, D.; Murph, M.; Mills, G. B.; Tigyi, G. Carba analogs of cyclic phosphatidic acid are selective inhibitors of autotaxin and cancer cell invasion and metastasis. J. Biol. Chem. 2006, 281, 22786-22793.

10. Fujiwara, Y. Cyclic phosphatidic acid-a unique bioactive phospholipid. Biochim. Biophys. Acta 2008, 1781, 519-524.

11. Vancura, A.; Haldar, D. Purification and characterization of glycerophosphate acyltransferase from rat liver mitochondria. J. Biol. Chem. 1994, 269, 2720927215. 
12. Bektas, M.; Payne, S. G.; Liu, H.; Goparaju, S.; Milstien, S.; Spiegel, S. A novel acylglycerol kinase that produces lysophosphatidic acid modulates cross talk with EGFR in prostate cancer cells. J. Cell Biol. 2005, 169, 801-811.

13. Das, A. K.; Milam, J. E.; Reddy, R. C.; Hajra, A. K. Facile syntheses of acyl dihydroxyacetone phosphates and lysophosphatidic acids having different acyl groups. J. Lipid Res. 2006, 47, 1874-1880.

14. Mishra, R. S.; Carnevale, K. A.; Cathcart, M. K. iPLA2beta: front and center in human monocyte chemotaxis to MCP-1. J. Exp. Med. 2008, 205, 347-359.

15. Stracke, M. L.; Arestad, A.; Levine, M.; Krutzsch, H. C.; Liotta, L. A. Autotaxin is an N-linked glycoprotein but the sugar moieties are not needed for its stimulation of cellular motility. Melanoma Res. 1995, 5, 203-209.

16. Umezu-Goto, M.; Kishi, Y.; Taira, A.; Hama, K.; Dohmae, N.; Takio, K.; Yamori, T.; Mills, G. B.; Inoue, K.; Aoki, J.; Arai, H. Autotaxin has lysophospholipase D activity leading to tumor cell growth and motility by lysophosphatidic acid production. J. Cell Biol. 2002, 158, 227-233.

17. Tokumura, A.; Majima, E.; Kariya, Y.; Tominaga, K.; Kogure, K.; Yasuda, K.; Fukuzawa, K. Identification of human plasma lysophospholipase D, a lysophosphatidic acid-producing enzyme, as autotaxin, a multifunctional phosphodiesterase. J. Biol. Chem. 2002, 277, 39436-39442.

18. Tsuda, S.; Okudaira, S.; Moriya-Ito, K.; Shimamoto, C.; Tanaka, M.; Aoki, J.; Arai, H.; Murakami-Murofushi, K.; Kobayashi, T. Cyclic phosphatidic acid is produced by autotaxin in blood. J. Biol. Chem. 2006, 281, 26081-26088.

19. van Meeteren, L. A.; Ruurs, P.; Christodoulou, E.; Goding, J. W.; Takakusa, H.; Kikuchi, K.; Perrakis, A.; Nagano, T.; Moolenaar, W. H. Inhibition of autotaxin by lysophosphatidic acid and sphingosine 1-phosphate. J. Biol. Chem. 2005, 280, 21155-21161.

20. Sano, T.; Baker, D.; Virag, T.; Wada, A.; Yatomi, Y.; Kobayashi, T.; Igarashi, Y.; Tigyi, G. Multiple mechanisms linked to platelet activation result in lysophosphatidic acid and sphingosine 1-phosphate generation in blood. J. Biol. Chem. 2002, 277, 21197-21206.

21. Siess, W.; Tigyi, G. Thrombogenic and atherogenic activities of lysophosphatidic acid. J. Cell Biochem. 2004, 92, 1086-1094.

22. Brindley, D. N. Lipid phosphate phosphatases and related proteins: signaling functions in development, cell division, and cancer. J. Cell Biochem. 2004, 92, 900912. 
23. Brindley, D. N.; Waggoner, D. W. Mammalian lipid phosphate phosphohydrolases. J. Biol. Chem. 1998, 273, 24281-24284.

24. Kai, M.; Wada, I.; Imai, S.; Sakane, F.; Kanoh, H. Cloning and characterization of two human isozymes of $\mathrm{Mg} 2+$-independent phosphatidic acid phosphatase. J. Biol. Chem. 1997, 272, 24572-24578.

25. Leung, D. W.; Tompkins, C. K.; White, T. Molecular cloning of two alternatively spliced forms of human phosphatidic acid phosphatase cDNAs that are differentially expressed in normal and tumor cells. DNA Cell Biol. 1998, 17, 377385 .

26. Roberts, R.; Sciorra, V. A.; Morris, A. J. Human type 2 phosphatidic acid phosphohydrolases. Substrate specificity of the type $2 a, 2 b$, and $2 c$ enzymes and cell surface activity of the 2a isoform. J. Biol. Chem. 1998, 273, 22059-22067.

27. Waggoner, D. W.; Gomez-Munoz, A.; Dewald, J.; Brindley, D. N. Phosphatidate phosphohydrolase catalyzes the hydrolysis of ceramide 1-phosphate, lysophosphatidate, and sphingosine 1-phosphate. J. Biol. Chem. 1996, 271, 1650616509.

28. Yokoyama, K.; Baker, D. L.; Virag, T.; Liliom, K.; Byun, H. S.; Tigyi, G.; Bittman, R. Stereochemical properties of lysophosphatidic acid receptor activation and metabolism. Biochim. Biophys. Acta 2002, 1582, 295-308.

29. Thompson, F. J.; Clark, M. A. Purification of a lysophosphatidic acid-hydrolysing lysophospholipase from rat brain. Biochem. J. 1994, 300 ( Pt 2), 457-461.

30. Wang, A.; Dennis, E. A. Mammalian lysophospholipases. Biochim. Biophys. Acta 1999, 1439, 1-16.

31. Wang, A.; Yang, H. C.; Friedman, P.; Johnson, C. A.; Dennis, E. A. A specific human lysophospholipase: cDNA cloning, tissue distribution and kinetic characterization. Biochim. Biophys. Acta 1999, 1437, 157-169.

32. Baker, R. R.; Chang, H. Y. Evidence for two distinct lysophospholipase activities that degrade lysophosphatidylcholine and lysophosphatidic acid in neuronal nuclei of cerebral cortex. Biochim. Biophys. Acta 1999, 1438, 253-263.

33. West, J.; Tompkins, C. K.; Balantac, N.; Nudelman, E.; Meengs, B.; White, T.; Bursten, S.; Coleman, J.; Kumar, A.; Singer, J. W.; Leung, D. W. Cloning and expression of two human lysophosphatidic acid acyltransferase cDNAs that enhance cytokine-induced signaling responses in cells. DNA Cell Biol. 1997, 16, 691-701. 
34. Eberhardt, C.; Gray, P. W.; Tjoelker, L. W. cDNA cloning, expression and chromosomal localization of two human lysophosphatidic acid acyltransferases. Adv. Exp. Med. Biol. 1999, 469, 351-356.

35. Leung, D. W. The structure and functions of human lysophosphatidic acid acyltransferases. Front Biosci. 2001, 6, D944-D953.

36. Hishikawa, D.; Shindou, H.; Kobayashi, S.; Nakanishi, H.; Taguchi, R.; Shimizu, T. Discovery of a lysophospholipid acyltransferase family essential for membrane asymmetry and diversity. Proc. Natl. Acad. Sci. U. S. A 2008, 105, 2830-2835.

37. Shindou, H.; Hishikawa, D.; Harayama, T.; Yuki, K.; Shimizu, T. Recent progress on acyl CoA: lysophospholipid acyltransferase research. J. Lipid Res. 2009, 50 Suppl, S46-S51.

38. Tigyi, G. Aiming drug discovery at lysophosphatidic acid targets. $B r . J$. Pharmacol. 2010, 161, 241-270.

39. Ishii, I.; Fukushima, N.; Ye, X.; Chun, J. Lysophospholipid receptors: signaling and biology. Annu. Rev. Biochem. 2004, 73, 321-354.

40. Noguchi, K.; Ishii, S.; Shimizu, T. Identification of p2y9/GPR23 as a novel G protein-coupled receptor for lysophosphatidic acid, structurally distant from the Edg family. J. Biol. Chem. 2003, 278, 25600-25606.

41. Hecht, J. H.; Weiner, J. A.; Post, S. R.; Chun, J. Ventricular zone gene-1 (vzg-1) encodes a lysophosphatidic acid receptor expressed in neurogenic regions of the developing cerebral cortex. J. Cell Biol. 1996, 135, 1071-1083.

42. An, S.; Dickens, M. A.; Bleu, T.; Hallmark, O. G.; Goetzl, E. J. Molecular cloning of the human Edg2 protein and its identification as a functional cellular receptor for lysophosphatidic acid. Biochem. Biophys. Res. Commun. 1997, 231, 619-622.

43. Fukushima, N.; Ishii, I.; Contos, J. J.; Weiner, J. A.; Chun, J. Lysophospholipid receptors. Annu. Rev. Pharmacol. Toxicol. 2001, 41, 507-534.

44. Fukushima, N.; Kimura, Y.; Chun, J. A single receptor encoded by vzg1/lpA1/edg-2 couples to $\mathrm{G}$ proteins and mediates multiple cellular responses to lysophosphatidic acid. Proc. Natl. Acad. Sci. U. S. A 1998, 95, 6151-6156.

45. Contos, J. J.; Chun, J. Complete cDNA sequence, genomic structure, and chromosomal localization of the LPA receptor gene, lpA1/vzg-1/Gpcr26. Genomics 1998, 51, 364-378. 
46. Meyer zu, H. D.; Jakobs, K. H. Lysophospholipid receptors: signalling, pharmacology and regulation by lysophospholipid metabolism. Biochim. Biophys. Acta 2007, 1768, 923-940.

47. An, S.; Bleu, T.; Hallmark, O. G.; Goetzl, E. J. Characterization of a novel subtype of human $\mathrm{G}$ protein-coupled receptor for lysophosphatidic acid. J. Biol. Chem. 1998, 273, 7906-7910.

48. An, S.; Bleu, T.; Zheng, Y.; Goetzl, E. J. Recombinant human G protein-coupled lysophosphatidic acid receptors mediate intracellular calcium mobilization. Mol. Pharmacol. 1998, 54, 881-888.

49. Bandoh, K.; Aoki, J.; Hosono, H.; Kobayashi, S.; Kobayashi, T.; MurakamiMurofushi, K.; Tsujimoto, M.; Arai, H.; Inoue, K. Molecular cloning and characterization of a novel human G-protein-coupled receptor, EDG7, for lysophosphatidic acid. J. Biol. Chem. 1999, 274, 27776-27785.

50. Lee, C. W.; Rivera, R.; Dubin, A. E.; Chun, J. LPA(4)/GPR23 is a lysophosphatidic acid (LPA) receptor utilizing $\mathrm{G}(\mathrm{s})-, \mathrm{G}(\mathrm{q}) / \mathrm{G}(\mathrm{i})$-mediated calcium signaling and G(12/13)-mediated Rho activation. J. Biol. Chem. 2007, 282, 4310-4317.

51. Lee, C. W.; Rivera, R.; Gardell, S.; Dubin, A. E.; Chun, J. GPR92 as a new G12/13-and Gq-coupled lysophosphatidic acid receptor that increases cAMP, LPA5. J. Biol. Chem. 2006, 281, 23589-23597.

52. Williams, J. R.; Khandoga, A. L.; Goyal, P.; Fells, J. I.; Perygin, D. H.; Siess, W.; Parrill, A. L.; Tigyi, G.; Fujiwara, Y. Unique ligand selectivity of the GPR92/LPA5 lysophosphatidate receptor indicates role in human platelet activation. J. Biol. Chem. 2009, 284, 17304-17319.

53. Kotarsky, K.; Boketoft, A.; Bristulf, J.; Nilsson, N. E.; Norberg, A.; Hansson, S.; Owman, C.; Sillard, R.; Leeb-Lundberg, L. M.; Olde, B. Lysophosphatidic acid binds to and activates GPR92, a G protein-coupled receptor highly expressed in gastrointestinal lymphocytes. J. Pharmacol. Exp. Ther. 2006, 318, 619-628.

54. Tabata, K.; Baba, K.; Shiraishi, A.; Ito, M.; Fujita, N. The orphan GPCR GPR87 was deorphanized and shown to be a lysophosphatidic acid receptor. Biochem. Biophys. Res. Commun. 2007, 363, 861-866.

55. Wetter, J. A.; Revankar, C.; Hanson, B. J. Utilization of the Tango beta-arrestin recruitment technology for cell-based EDG receptor assay development and interrogation. J. Biomol. Screen. 2009, 14, 1134-1141.

56. Gugger, M.; White, R.; Song, S.; Waser, B.; Cescato, R.; Riviere, P.; Reubi, J. C. GPR87 is an overexpressed G-protein coupled receptor in squamous cell carcinoma of the lung. Dis. Markers 2008, 24, 41-50. 
57. Pasternack, S. M.; von, K., I; Aboud, K. A.; Lee, Y. A.; Ruschendorf, F.; Voss, K.; Hillmer, A. M.; Molderings, G. J.; Franz, T.; Ramirez, A.; Nurnberg, P.; Nothen, M. M.; Betz, R. C. G protein-coupled receptor P2Y5 and its ligand LPA are involved in maintenance of human hair growth. Nat. Genet. 2008, 40, 329-334.

58. Shimomura, Y.; Garzon, M. C.; Kristal, L.; Shapiro, L.; Christiano, A. M. Autosomal recessive woolly hair with hypotrichosis caused by a novel homozygous mutation in the P2RY5 gene. Exp. Dermatol. 2009, 18, 218-221.

59. Murakami, M.; Shiraishi, A.; Tabata, K.; Fujita, N. Identification of the orphan GPCR, P2Y(10) receptor as the sphingosine-1-phosphate and lysophosphatidic acid receptor. Biochem. Biophys. Res. Commun. 2008, 371, 707-712.

60. McIntyre, T. M.; Pontsler, A. V.; Silva, A. R.; St Hilaire, A.; Xu, Y.; Hinshaw, J. C.; Zimmerman, G. A.; Hama, K.; Aoki, J.; Arai, H.; Prestwich, G. D. Identification of an intracellular receptor for lysophosphatidic acid (LPA): LPA is a transcellular PPARgamma agonist. Proc. Natl. Acad. Sci. U. S. A 2003, 100, 131136.

61. Tsukahara, T.; Tsukahara, R.; Yasuda, S.; Makarova, N.; Valentine, W. J.; Allison, P.; Yuan, H.; Baker, D. L.; Li, Z.; Bittman, R.; Parrill, A.; Tigyi, G. Different residues mediate recognition of 1-O-oleyllysophosphatidic acid and rosiglitazone in the ligand binding domain of peroxisome proliferator-activated receptor gamma. $J$. Biol. Chem. 2006, 281, 3398-3407.

62. Zhang, C.; Baker, D. L.; Yasuda, S.; Makarova, N.; Balazs, L.; Johnson, L. R.; Marathe, G. K.; McIntyre, T. M.; Xu, Y.; Prestwich, G. D.; Byun, H. S.; Bittman, R.; Tigyi, G. Lysophosphatidic acid induces neointima formation through PPARgamma activation. J. Exp. Med. 2004, 199, 763-774.

63. Panupinthu, N.; Lee, H. Y.; Mills, G. B. Lysophosphatidic acid production and action: critical new players in breast cancer initiation and progression. $B r . J$. Cancer 2010, 102, 941-946.

64. Deng, W.; Shuyu, E.; Tsukahara, R.; Valentine, W. J.; Durgam, G.; Gududuru, V.; Balazs, L.; Manickam, V.; Arsura, M.; VanMiddlesworth, L.; Johnson, L. R.; Parrill, A. L.; Miller, D. D.; Tigyi, G. The lysophosphatidic acid type 2 receptor is required for protection against radiation-induced intestinal injury. Gastroenterology 2007, 132, 1834-1851.

65. E S; Lai, Y. J.; Tsukahara, R.; Chen, C. S.; Fujiwara, Y.; Yue, J.; Yu, J. H.; Guo, H.; Kihara, A.; Tigyi, G.; Lin, F. T. Lysophosphatidic acid 2 receptor-mediated supramolecular complex formation regulates its antiapoptotic effect. J. Biol. Chem. 2009, 284, 14558-14571. 
66. Fang, X.; Yu, S.; LaPushin, R.; Lu, Y.; Furui, T.; Penn, L. Z.; Stokoe, D.; Erickson, J. R.; Bast, R. C., Jr.; Mills, G. B. Lysophosphatidic acid prevents apoptosis in fibroblasts via G(i)-protein-mediated activation of mitogen-activated protein kinase. Biochem. J. 2000, 352 Pt 1, 135-143.

67. Lin, F. T.; Lai, Y. J.; Makarova, N.; Tigyi, G.; Lin, W. C. The lysophosphatidic acid 2 receptor mediates down-regulation of Siva-1 to promote cell survival. $J$. Biol. Chem. 2007, 282, 37759-37769.

68. Yamada, T.; Ohoka, Y.; Kogo, M.; Inagaki, S. Physical and functional interactions of the lysophosphatidic acid receptors with PDZ domain-containing Rho guanine nucleotide exchange factors (RhoGEFs). J. Biol. Chem. 2005, 280, 19358-19363.

69. Zhang, H.; Bialkowska, A.; Rusovici, R.; Chanchevalap, S.; Shim, H.; Katz, J. P.; Yang, V. W.; Yun, C. C. Lysophosphatidic acid facilitates proliferation of colon cancer cells via induction of Kruppel-like factor 5. J. Biol. Chem. 2007, 282, 15541-15549.

70. Zhang, H.; Wang, D.; Sun, H.; Hall, R. A.; Yun, C. C. MAGI-3 regulates LPAinduced activation of Erk and RhoA. Cell Signal. 2007, 19, 261-268.

71. Chu, F.; Borthakur, A.; Sun, X.; Barkinge, J.; Gudi, R.; Hawkins, S.; Prasad, K. V. The Siva-1 putative amphipathic helical region (SAH) is sufficient to bind to BCLXL and sensitize cells to UV radiation induced apoptosis. Apoptosis. 2004, 9, 83-95.

72. Reed, J. C.; Green, D. R. Remodeling for demolition: changes in mitochondrial ultrastructure during apoptosis. Mol. Cell 2002, 9, 1-3.

73. Scorrano, L.; Korsmeyer, S. J. Mechanisms of cytochrome c release by proapoptotic BCL-2 family members. Biochem. Biophys. Res. Commun. 2003, 304, 437-444.

74. Davidson, B.; Goldberg, I.; Gotlieb, W. H.; Kopolovic, J.; Ben-Baruch, G.; Nesland, J. M.; Berner, A.; Bryne, M.; Reich, R. High levels of MMP-2, MMP-9, MT1-MMP and TIMP-2 mRNA correlate with poor survival in ovarian carcinoma. Clin. Exp. Metastasis 1999, 17, 799-808.

75. Davidson, B.; Goldberg, I.; Kopolovic, J.; Lerner-Geva, L.; Gotlieb, W. H.; BenBaruch, G.; Reich, R. MMP-2 and TIMP-2 expression correlates with poor prognosis in cervical carcinoma-- a clinicopathologic study using immunohistochemistry and mRNA in situ hybridization. Gynecol. Oncol. 1999, 73, 372-382. 
76. Schmalfeldt, B.; Prechtel, D.; Harting, K.; Spathe, K.; Rutke, S.; Konik, E.; Fridman, R.; Berger, U.; Schmitt, M.; Kuhn, W.; Lengyel, E. Increased expression of matrix metalloproteinases (MMP)-2, MMP-9, and the urokinase-type plasminogen activator is associated with progression from benign to advanced ovarian cancer. Clin. Cancer Res. 2001, 7, 2396-2404.

77. Contos, J. J.; Fukushima, N.; Weiner, J. A.; Kaushal, D.; Chun, J. Requirement for the lpA1 lysophosphatidic acid receptor gene in normal suckling behavior. Proc. Natl. Acad. Sci. U. S. A 2000, 97, 13384-13389.

78. Li, Y.; Gonzalez, M. I.; Meinkoth, J. L.; Field, J.; Kazanietz, M. G.; Tennekoon, G. I. Lysophosphatidic acid promotes survival and differentiation of rat Schwann cells. J. Biol. Chem. 2003, 278, 9585-9591.

79. Moller, T.; Musante, D. B.; Ransom, B. R. Lysophosphatidic acid-induced calcium signals in cultured rat oligodendrocytes. Neuroreport 1999, 10, 2929-2932.

80. Nogaroli, L.; Yuelling, L. M.; Dennis, J.; Gorse, K.; Payne, S. G.; Fuss, B. Lysophosphatidic acid can support the formation of membranous structures and an increase in MBP mRNA levels in differentiating oligodendrocytes. Neurochem. Res. 2009, 34, 182-193.

81. Weiner, J. A.; Hecht, J. H.; Chun, J. Lysophosphatidic acid receptor gene vzg$1 / \mathrm{pA} 1 / \mathrm{edg}-2$ is expressed by mature oligodendrocytes during myelination in the postnatal murine brain. J. Comp Neurol. 1998, 398, 587-598.

82. Dubin, A. E.; Bahnson, T.; Weiner, J. A.; Fukushima, N.; Chun, J. Lysophosphatidic acid stimulates neurotransmitter-like conductance changes that precede GABA and L-glutamate in early, presumptive cortical neuroblasts. $J$. Neurosci. 1999, 19, 1371-1381.

83. Kingsbury, M. A.; Rehen, S. K.; Contos, J. J.; Higgins, C. M.; Chun, J. Nonproliferative effects of lysophosphatidic acid enhance cortical growth and folding. Nat. Neurosci. 2003, 6, 1292-1299.

84. Estivill-Torrus, G.; Llebrez-Zayas, P.; Matas-Rico, E.; Santin, L.; Pedraza, C.; De, D., I; Del, A., I; Fernandez-Llebrez, P.; Chun, J.; De Fonseca, F. R. Absence of LPA1 signaling results in defective cortical development. Cereb. Cortex 2008, 18, 938-950.

85. Matas-Rico, E.; Garcia-Diaz, B.; Llebrez-Zayas, P.; Lopez-Barroso, D.; Santin, L.; Pedraza, C.; Smith-Fernandez, A.; Fernandez-Llebrez, P.; Tellez, T.; Redondo, M.; Chun, J.; De Fonseca, F. R.; Estivill-Torrus, G. Deletion of lysophosphatidic acid receptor LPA1 reduces neurogenesis in the mouse dentate gyrus. Mol. Cell Neurosci. 2008, 39, 342-355. 
86. Inoue, M.; Xie, W.; Matsushita, Y.; Chun, J.; Aoki, J.; Ueda, H.

Lysophosphatidylcholine induces neuropathic pain through an action of autotaxin to generate lysophosphatidic acid. Neuroscience 2008, 152, 296-298.

87. Wallace, V. C.; Cottrell, D. F.; Brophy, P. J.; Fleetwood-Walker, S. M. Focal lysolecithin-induced demyelination of peripheral afferents results in neuropathic pain behavior that is attenuated by cannabinoids. J. Neurosci. 2003, 23, 3221-3233.

88. Ahn, D. K.; Lee, S. Y.; Han, S. R.; Ju, J. S.; Yang, G. Y.; Lee, M. K.; Youn, D. H.; Bae, Y. C. Intratrigeminal ganglionic injection of LPA causes neuropathic pain-like behavior and demyelination in rats. Pain 2009, 146, 114-120.

89. Siess, W.; Tigyi, G. Thrombogenic and atherogenic activities of lysophosphatidic acid. J. Cell Biochem. 2004, 92, 1086-1094.

90. Siess, W. Athero-and thrombogenic actions of lysophosphatidic acid and sphingosine-1-phosphate. Biochim. Biophys. Acta 2002, 1582, 204-215.

91. Siess, W.; Zangl, K. J.; Essler, M.; Bauer, M.; Brandl, R.; Corrinth, C.; Bittman, R.; Tigyi, G.; Aepfelbacher, M. Lysophosphatidic acid mediates the rapid activation of platelets and endothelial cells by mildly oxidized low density lipoprotein and accumulates in human atherosclerotic lesions. Proc. Natl. Acad. Sci. U. S. A 1999, 96, 6931-6936.

92. Essler, M.; Retzer, M.; Bauer, M.; Zang1, K. J.; Tigyi, G.; Siess, W. Stimulation of platelets and endothelial cells by mildly oxidized LDL proceeds through activation of lysophosphatidic acid receptors and the Rho/Rho-kinase pathway. Inhibition by lovastatin. Ann. N. Y. Acad. Sci. 2000, 905, 282-286.

93. Tigyi, G.; Hong, L.; Yakubu, M.; Parfenova, H.; Shibata, M.; Leffler, C. W. Lysophosphatidic acid alters cerebrovascular reactivity in piglets. Am. J. Physiol 1995, 268, H2048-H2055.

94. Tigyi, G. Physiological responses to lysophosphatidic acid and related glycerophospholipids. Prostaglandins 2001, 64, 47-62.

95. van Corven, E. J.; Groenink, A.; Jalink, K.; Eichholtz, T.; Moolenaar, W. H. Lysophosphatidate-induced cell proliferation: identification and dissection of signaling pathways mediated by G proteins. Cell 1989, 59, 45-54.

96. van Corven, E. J.; van, R. A.; Jalink, K.; van der Bend, R. L.; van Blitterswijk, W. J.; Moolenaar, W. H. Mitogenic action of lysophosphatidic acid and phosphatidic acid on fibroblasts. Dependence on acyl-chain length and inhibition by suramin. Biochem. J. 1992, 281 (Pt 1), 163-169. 
97. Hahn, A.; Heusinger-Ribeiro, J.; Lanz, T.; Zenkel, S.; Goppelt-Struebe, M. Induction of connective tissue growth factor by activation of heptahelical receptors. Modulation by Rho proteins and the actin cytoskeleton. J. Biol. Chem. 2000, 275, 37429-37435.

98. Muehlich, S.; Schneider, N.; Hinkmann, F.; Garlichs, C. D.; Goppelt-Struebe, M. Induction of connective tissue growth factor (CTGF) in human endothelial cells by lysophosphatidic acid, sphingosine-1-phosphate, and platelets. Atherosclerosis 2004, 175, 261-268.

99. Vial, C.; Zuniga, L. M.; Cabello-Verrugio, C.; Canon, P.; Fadic, R.; Brandan, E. Skeletal muscle cells express the profibrotic cytokine connective tissue growth factor (CTGF/CCN2), which induces their dedifferentiation. J. Cell Physiol 2008, $215,410-421$.

100. Pradere, J. P.; Klein, J.; Gres, S.; Guigne, C.; Neau, E.; Valet, P.; Calise, D.; Chun, J.; Bascands, J. L.; Saulnier-Blache, J. S.; Schanstra, J. P. LPA1 receptor activation promotes renal interstitial fibrosis. J. Am. Soc. Nephrol. 2007, 18, 3110-3118.

101. Watanabe, N.; Ikeda, H.; Nakamura, K.; Ohkawa, R.; Kume, Y.; Aoki, J.; Hama, K.; Okudaira, S.; Tanaka, M.; Tomiya, T.; Yanase, M.; Tejima, K.; Nishikawa, T.; Arai, M.; Arai, H.; Omata, M.; Fujiwara, K.; Yatomi, Y. Both plasma lysophosphatidic acid and serum autotaxin levels are increased in chronic hepatitis C. J. Clin. Gastroenterol. 2007, 41, 616-623.

102. Watanabe, N.; Ikeda, H.; Nakamura, K.; Ohkawa, R.; Kume, Y.; Tomiya, T.; Tejima, K.; Nishikawa, T.; Arai, M.; Yanase, M.; Aoki, J.; Arai, H.; Omata, M.; Fujiwara, K.; Yatomi, Y. Plasma lysophosphatidic acid level and serum autotaxin activity are increased in liver injury in rats in relation to its severity. Life Sci. 2007, 81, 1009-1015.

103. Tager, A. M.; LaCamera, P.; Shea, B. S.; Campanella, G. S.; Selman, M.; Zhao, Z.; Polosukhin, V.; Wain, J.; Karimi-Shah, B. A.; Kim, N. D.; Hart, W. K.; Pardo, A.; Blackwell, T. S.; Xu, Y.; Chun, J.; Luster, A. D. The lysophosphatidic acid receptor LPA1 links pulmonary fibrosis to lung injury by mediating fibroblast recruitment and vascular leak. Nat. Med. 2008, 14, 45-54.

104. Xu, M. Y.; Porte, J.; Knox, A. J.; Weinreb, P. H.; Maher, T. M.; Violette, S. M.; McAnulty, R. J.; Sheppard, D.; Jenkins, G. Lysophosphatidic acid induces alphavbeta6 integrin-mediated TGF-beta activation via the LPA2 receptor and the small G protein G alpha(q). Am. J. Pathol. 2009, 174, 1264-1279.

105. Tigyi, G. Aiming drug discovery at lysophosphatidic acid targets. $B r . J$. Pharmacol. 2010, 161, 241-270. 
106. Caverzasio, J.; Palmer, G.; Suzuki, A.; Bonjour, J. P. Evidence for the involvement of two pathways in activation of extracellular signal-regulated kinase (Erk) and cell proliferation by Gi and Gq protein-coupled receptors in osteoblast-like cells. $J$. Bone Miner. Res. 2000, 15, 1697-1706.

107. Grey, A.; Banovic, T.; Naot, D.; Hill, B.; Callon, K.; Reid, I.; Cornish, J. Lysophosphatidic acid is an osteoblast mitogen whose proliferative actions involve $\mathrm{G}(\mathrm{i})$ proteins and protein kinase $\mathrm{C}$, but not P42/44 mitogen-activated protein kinases. Endocrinology 2001, 142, 1098-1106.

108. Lyons, J. M.; Karin, N. J. A role for G protein-coupled lysophospholipid receptors in sphingolipid-induced $\mathrm{Ca} 2+$ signaling in MC3T3-E1 osteoblastic cells. J. Bone Miner. Res. 2001, 16, 2035-2042.

109. Grey, A.; Chen, Q.; Callon, K.; Xu, X.; Reid, I. R.; Cornish, J. The phospholipids sphingosine-1-phosphate and lysophosphatidic acid prevent apoptosis in osteoblastic cells via a signaling pathway involving G(i) proteins and phosphatidylinositol-3 kinase. Endocrinology 2002, 143, 4755-4763.

110. Dziak, R.; Yang, B. M.; Leung, B. W.; Li, S.; Marzec, N.; Margarone, J.; Bobek, L. Effects of sphingosine-1-phosphate and lysophosphatidic acid on human osteoblastic cells. Prostaglandins Leukot. Essent. Fatty Acids 2003, 68, 239-249.

111. Karagiosis, S. A.; Karin, N. J. Lysophosphatidic acid induces osteocyte dendrite outgrowth. Biochem. Biophys. Res. Commun. 2007, 357, 194-199.

112. Goetzl, E. J.; Kong, Y.; Voice, J. K. Cutting edge: differential constitutive expression of functional receptors for lysophosphatidic acid by human blood lymphocytes. J. Immunol. 2000, 164, 4996-4999.

113. Perova, T.; Wasserman, M. J.; Li, P. P.; Warsh, J. J. Hyperactive intracellular calcium dynamics in B lymphoblasts from patients with bipolar I disorder. Int. $J$. Neuropsychopharmacol. 2008, 11, 185-196.

114. Rosskopf, D.; Daelman, W.; Busch, S.; Schurks, M.; Hartung, K.; Kribben, A.; Michel, M. C.; Siffert, W. Growth factor-like action of lysophosphatidic acid on human B lymphoblasts. Am. J. Physiol 1998, 274, C1573-C1582.

115. Satoh, Y.; Ohkawa, R.; Nakamura, K.; Higashi, K.; Kaneko, M.; Yokota, H.; Aoki, J.; Arai, H.; Yuasa, Y.; Yatomi, Y. Lysophosphatidic acid protection against apoptosis in the human pre-B-cell line Nalm-6. Eur. J. Haematol. 2007, 78, 510517. 
116. Idzko, M.; Laut, M.; Panther, E.; Sorichter, S.; Durk, T.; Fluhr, J. W.; Herouy, Y.; Mockenhaupt, M.; Myrtek, D.; Elsner, P.; Norgauer, J. Lysophosphatidic acid induces chemotaxis, oxygen radical production, $\mathrm{CD} 11 \mathrm{~b}$ up-regulation, $\mathrm{Ca} 2+$ mobilization, and actin reorganization in human eosinophils via pertussis toxinsensitive G proteins. J. Immunol. 2004, 172, 4480-4485.

117. Chettibi, S.; Lawrence, A. J.; Stevenson, R. D.; Young, J. D. Effect of lysophosphatidic acid on motility, polarisation and metabolic burst of human neutrophils. FEMS Immunol. Med. Microbiol. 1994, 8, 271-281.

118. Hornuss, C.; Hammermann, R.; Fuhrmann, M.; Juergens, U. R.; Racke, K. Human and rat alveolar macrophages express multiple EDG receptors. Eur. J. Pharmacol. 2001, 429, 303-308.

119. Bagga, S.; Price, K. S.; Lin, D. A.; Friend, D. S.; Austen, K. F.; Boyce, J. A. Lysophosphatidic acid accelerates the development of human mast cells. Blood 2004, 104, 4080-4087.

120. Chan, L. C.; Peters, W.; Xu, Y.; Chun, J.; Farese, R. V., Jr.; Cases, S. LPA3 receptor mediates chemotaxis of immature murine dendritic cells to unsaturated lysophosphatidic acid (LPA). J. Leukoc. Biol. 2007, 82, 1193-1200.

121. Llodra, J.; Angeli, V.; Liu, J.; Trogan, E.; Fisher, E. A.; Randolph, G. J. Emigration of monocyte-derived cells from atherosclerotic lesions characterizes regressive, but not progressive, plaques. Proc. Natl. Acad. Sci. U. S. A 2004, 101, 11779-11784.

122. Panther, E.; Idzko, M.; Corinti, S.; Ferrari, D.; Herouy, Y.; Mockenhaupt, M.; Dichmann, S.; Gebicke-Haerter, P.; Di, V. F.; Girolomoni, G.; Norgauer, J. The influence of lysophosphatidic acid on the functions of human dendritic cells. $J$. Immunol. 2002, 169, 4129-4135.

123. Jin, Y.; Knudsen, E.; Wang, L.; Maghazachi, A. A. Lysophosphatidic acid induces human natural killer cell chemotaxis and intracellular calcium mobilization. Eur. $J$. Immunol. 2003, 33, 2083-2089.

124. Jo, S. H.; Kim, S. D.; Kim, J. M.; Lee, H. Y.; Lee, S. Y.; Shim, J. W.; Yun, J.; Im, D. S.; Bae, Y. S. Lysophosphatidylglycerol stimulates chemotactic migration in human natural killer cells. Biochem. Biophys. Res. Commun. 2008, 372, 147-151.

125. Maghazachi, A. A. G protein-coupled receptors in natural killer cells. J. Leukoc. Biol. 2003, 74, 16-24.

126. Leslie, D. S.; Vincent, M. S.; Spada, F. M.; Das, H.; Sugita, M.; Morita, C. T.; Brenner, M. B. CD1-mediated gamma/delta T cell maturation of dendritic cells. $J$. Exp. Med. 2002, 196, 1575-1584. 
127. Vincent, M. S.; Gumperz, J. E.; Brenner, M. B. Understanding the function of CD1-restricted T cells. Nat. Immunol. 2003, 4, 517-523.

128. Vincent, M. S.; Leslie, D. S.; Gumperz, J. E.; Xiong, X.; Grant, E. P.; Brenner, M. B. CD1-dependent dendritic cell instruction. Nat. Immunol. 2002, 3, 1163-1168.

129. Sieling, P. A.; Porcelli, S. A.; Duong, B. T.; Spada, F.; Bloom, B. R.; Diamond, B.; Hahn, B. H. Human double-negative T cells in systemic lupus erythematosus provide help for IgG and are restricted by CD1c. J. Immunol. 2000, 165, 53385344.

130. DeLibero, L. G.; Donda, A.; Gober, H. J.; Manolova, V.; Mazorra, Z.; Shamshiev, A.; Mori, L. A new aspect in glycolipid biology: glycosphingolipids as antigens recognized by T lymphocytes. Neurochem. Res. 2002, 27, 675-685.

131. Roura-Mir, C.; Catalfamo, M.; Cheng, T. Y.; Marqusee, E.; Besra, G. S.; Jaraquemada, D.; Moody, D. B. CD1a and CD1c activate intrathyroidal T cells during Graves' disease and Hashimoto's thyroiditis. J. Immunol. 2005, 174, 37733780 .

132. Yang, Y.; Mou, L.; Liu, N.; Tsao, M. S. Autotaxin expression in non-small-cell lung cancer. Am. J. Respir. Cell Mol. Biol. 1999, 21, 216-222.

133. Wu, J. M.; Xu, Y.; Skill, N. J.; Sheng, H.; Zhao, Z.; Yu, M.; Saxena, R.; Maluccio, M. A. Autotaxin expression and its connection with the TNF-alpha-NF-kappaB axis in human hepatocellular carcinoma. Mol. Cancer 2010, 9, 71.

134. Liu, S.; Umezu-Goto, M.; Murph, M.; Lu, Y.; Liu, W.; Zhang, F.; Yu, S.; Stephens, L. C.; Cui, X.; Murrow, G.; Coombes, K.; Muller, W.; Hung, M. C.; Perou, C. M.; Lee, A. V.; Fang, X.; Mills, G. B. Expression of autotaxin and lysophosphatidic acid receptors increases mammary tumorigenesis, invasion, and metastases. Cancer Cell 2009, 15, 539-550.

135. Vidot, S.; Witham, J.; Agarwal, R.; Greenhough, S.; Bamrah, H. S.; Tigyi, G. J.; Kaye, S. B.; Richardson, A. Autotaxin delays apoptosis induced by carboplatin in ovarian cancer cells. Cell Signal. 2010, 22, 926-935.

136. Kehlen, A.; Englert, N.; Seifert, A.; Klonisch, T.; Dralle, H.; Langner, J.; Hoang$\mathrm{Vu}, \mathrm{C}$. Expression, regulation and function of autotaxin in thyroid carcinomas. Int. J. Cancer 2004, 109, 833-838.

137. Nouh, M. A.; Wu, X. X.; Okazoe, H.; Tsunemori, H.; Haba, R.; Abou-Zeid, A. M.; Saleem, M. D.; Inui, M.; Sugimoto, M.; Aoki, J.; Kakehi, Y. Expression of autotaxin and acylglycerol kinase in prostate cancer: association with cancer development and progression. Cancer Sci. 2009, 100, 1631-1638. 
138. Masuda, A.; Nakamura, K.; Izutsu, K.; Igarashi, K.; Ohkawa, R.; Jona, M.; Higashi, K.; Yokota, H.; Okudaira, S.; Kishimoto, T.; Watanabe, T.; Koike, Y.; Ikeda, H.; Kozai, Y.; Kurokawa, M.; Aoki, J.; Yatomi, Y. Serum autotaxin measurement in haematological malignancies: a promising marker for follicular lymphoma. Br. J. Haematol. 2008, 143, 60-70.

139. Kishi, Y.; Okudaira, S.; Tanaka, M.; Hama, K.; Shida, D.; Kitayama, J.; Yamori, T.; Aoki, J.; Fujimaki, T.; Arai, H. Autotaxin is overexpressed in glioblastoma multiforme and contributes to cell motility of glioblastoma by converting lysophosphatidylcholine to lysophosphatidic acid. J. Biol. Chem. 2006, 281, 1749217500 .

140. Samadi, N.; Gaetano, C.; Goping, I. S.; Brindley, D. N. Autotaxin protects MCF-7 breast cancer and MDA-MB-435 melanoma cells against Taxol-induced apoptosis. Oncogene 2009, 28, 1028-1039.

141. Goding, J. W.; Grobben, B.; Slegers, H. Physiological and pathophysiological functions of the ecto-nucleotide pyrophosphatase/phosphodiesterase family. Biochim. Biophys. Acta 2003, 1638, 1-19.

142. van Meeteren, L. A.; Moolenaar, W. H. Regulation and biological activities of the autotaxin-LPA axis. Prog. Lipid Res. 2007, 46, 145-160.

143. Gupte, R.; Siddam, A.; Lu, Y.; Li, W.; Fujiwara, Y.; Panupinthu, N.; Pham, T. C.; Baker, D. L.; Parrill, A. L.; Gotoh, M.; Murakami-Murofushi, K.; Kobayashi, S.; Mills, G. B.; Tigyi, G.; Miller, D. D. Synthesis and pharmacological evaluation of the stereoisomers of 3-carba cyclic-phosphatidic acid. Bioorg. Med. Chem. Lett. 2010, 20, 7525-7528.

144. Uchiyama, A.; Mukai, M.; Fujiwara, Y.; Kobayashi, S.; Kawai, N.; Murofushi, H.; Inoue, M.; Enoki, S.; Tanaka, Y.; Niki, T.; Kobayashi, T.; Tigyi, G.; MurakamiMurofushi, K. Inhibition of transcellular tumor cell migration and metastasis by novel carba-derivatives of cyclic phosphatidic acid. Biochim. Biophys. Acta 2007, $1771,103-112$.

145. Tsuda, S.; Okudaira, S.; Moriya-Ito, K.; Shimamoto, C.; Tanaka, M.; Aoki, J.; Arai, H.; Murakami-Murofushi, K.; Kobayashi, T. Cyclic phosphatidic acid is produced by autotaxin in blood. J. Biol. Chem. 2006, 281, 26081-26088.

146. Ferguson, C. G.; Bigman, C. S.; Richardson, R. D.; van Meeteren, L. A.; Moolenaar, W. H.; Prestwich, G. D. Fluorogenic phospholipid substrate to detect lysophospholipase D/autotaxin activity. Org. Lett. 2006, 8, 2023-2026.

147. Hoeglund, A. B.; Bostic, H. E.; Howard, A. L.; Wanjala, I. W.; Best, M. D.; Baker, D. L.; Parrill, A. L. Optimization of a pipemidic acid autotaxin inhibitor. J. Med. Chem. 2010, 53, 1056-1066. 
148. North, E. J.; Osborne, D. A.; Bridson, P. K.; Baker, D. L.; Parrill, A. L. Autotaxin structure-activity relationships revealed through lysophosphatidylcholine analogs. Bioorg. Med. Chem. 2009, 17, 3433-3442.

149. North, E. J.; Howard, A. L.; Wanjala, I. W.; Pham, T. C.; Baker, D. L.; Parrill, A. L. Pharmacophore development and application toward the identification of novel, small-molecule autotaxin inhibitors. J. Med. Chem. 2010, 53, 3095-3105.

150. Durgam, G. G.; Virag, T.; Walker, M. D.; Tsukahara, R.; Yasuda, S.; Liliom, K.; van Meeteren, L. A.; Moolenaar, W. H.; Wilke, N.; Siess, W.; Tigyi, G.; Miller, D. D. Synthesis, structure-activity relationships, and biological evaluation of fatty alcohol phosphates as lysophosphatidic acid receptor ligands, activators of PPARgamma, and inhibitors of autotaxin. J. Med. Chem. 2005, 48, 4919-4930.

151. Gupte, R.; Patil, R.; Liu, J.; Wang, Y.; Lee, S. C.; Fujiwara, Y.; Fells, J.; Bolen, A. L.; Emmons-Thompson, K.; Yates, C. R.; Siddam, A.; Panupinthu, N.; Pham, T. C.; Baker, D. L.; Parrill, A. L.; Mills, G. B.; Tigyi, G.; Miller, D. D. Benzyl and naphthalene methylphosphonic acid inhibitors of autotaxin with anti-invasive and anti-metastatic activity. ChemMedChem. 2011, 6, 922-935.

152. Gaetano, C. G.; Samadi, N.; Tomsig, J. L.; Macdonald, T. L.; Lynch, K. R.; Brindley, D. N. Inhibition of autotaxin production or activity blocks lysophosphatidylcholine-induced migration of human breast cancer and melanoma cells. Mol. Carcinog. 2009, 48, 801-809.

153. Sakagami, H.; Aoki, J.; Natori, Y.; Nishikawa, K.; Kakehi, Y.; Natori, Y.; Arai, H. Biochemical and molecular characterization of a novel choline-specific glycerophosphodiester phosphodiesterase belonging to the nucleotide pyrophosphatase/phosphodiesterase family. J. Biol. Chem. 2005, 280, 2308423093.

154. Duan, R. D.; Bergman, T.; Xu, N.; Wu, J.; Cheng, Y.; Duan, J.; Nelander, S.; Palmberg, C.; Nilsson, A. Identification of human intestinal alkaline sphingomyelinase as a novel ecto-enzyme related to the nucleotide phosphodiesterase family. J. Biol. Chem. 2003, 278, 38528-38536.

155. Wu, J.; Nilsson, A.; Jonsson, B. A.; Stenstad, H.; Agace, W.; Cheng, Y.; Duan, R. D. Intestinal alkaline sphingomyelinase hydrolyses and inactivates plateletactivating factor by a phospholipase C activity. Biochem. J. 2006, 394, 299-308.

156. Tanaka, M.; Okudaira, S.; Kishi, Y.; Ohkawa, R.; Iseki, S.; Ota, M.; Noji, S.; Yatomi, Y.; Aoki, J.; Arai, H. Autotaxin stabilizes blood vessels and is required for embryonic vasculature by producing lysophosphatidic acid. J. Biol. Chem. 2006, $281,25822-25830$. 
157. van Meeteren, L. A.; Ruurs, P.; Stortelers, C.; Bouwman, P.; van Rooijen, M. A.; Pradere, J. P.; Pettit, T. R.; Wakelam, M. J.; Saulnier-Blache, J. S.; Mummery, C. L.; Moolenaar, W. H.; Jonkers, J. Autotaxin, a secreted lysophospholipase D, is essential for blood vessel formation during development. Mol. Cell Biol. 2006, 26, 5015-5022.

158. Fotopoulou, S.; Oikonomou, N.; Grigorieva, E.; Nikitopoulou, I.; Paparountas, T.; Thanassopoulou, A.; Zhao, Z.; Xu, Y.; Kontoyiannis, D. L.; Remboutsika, E.; Aidinis, V. ATX expression and LPA signalling are vital for the development of the nervous system. Dev. Biol. 2010, 339, 451-464.

159. Sutphen, R.; Xu, Y.; Wilbanks, G. D.; Fiorica, J.; Grendys, E. C., Jr.; LaPolla, J. P.; Arango, H.; Hoffman, M. S.; Martino, M.; Wakeley, K.; Griffin, D.; Blanco, R. W.; Cantor, A. B.; Xiao, Y. J.; Krischer, J. P. Lysophospholipids are potential biomarkers of ovarian cancer. Cancer Epidemiol. Biomarkers Prev. 2004, 13, 1185-1191.

160. Xu, Y.; Gaudette, D. C.; Boynton, J. D.; Frankel, A.; Fang, X. J.; Sharma, A.; Hurteau, J.; Casey, G.; Goodbody, A.; Mellors, A.; . Characterization of an ovarian cancer activating factor in ascites from ovarian cancer patients. Clin. Cancer Res. 1995, 1, 1223-1232.

161. Dimova, I.; Raitcheva, S.; Dimitrov, R.; Doganov, N.; Toncheva, D. Correlations between c-myc gene copy-number and clinicopathological parameters of ovarian tumours. Eur. J. Cancer 2006, 42, 674-679.

162. Euer, N.; Schwirzke, M.; Evtimova, V.; Burtscher, H.; Jarsch, M.; Tarin, D.; Weidle, U. H. Identification of genes associated with metastasis of mammary carcinoma in metastatic versus non-metastatic cell lines. Anticancer Res. 2002, 22, $733-740$.

163. Liu, S.; Umezu-Goto, M.; Murph, M.; Lu, Y.; Liu, W.; Zhang, F.; Yu, S.; Stephens, L. C.; Cui, X.; Murrow, G.; Coombes, K.; Muller, W.; Hung, M. C.; Perou, C. M.; Lee, A. V.; Fang, X.; Mills, G. B. Expression of autotaxin and lysophosphatidic acid receptors increases mammary tumorigenesis, invasion, and metastases. Cancer Cell 2009, 15, 539-550.

164. Jazaeri, A. A.; Awtrey, C. S.; Chandramouli, G. V.; Chuang, Y. E.; Khan, J.; Sotiriou, C.; Aprelikova, O.; Yee, C. J.; Zorn, K. K.; Birrer, M. J.; Barrett, J. C.; Boyd, J. Gene expression profiles associated with response to chemotherapy in epithelial ovarian cancers. Clin. Cancer Res. 2005, 11, 6300-6310. 
165. Durgam, G. G.; Tsukahara, R.; Makarova, N.; Walker, M. D.; Fujiwara, Y.; Pigg, K. R.; Baker, D. L.; Sardar, V. M.; Parrill, A. L.; Tigyi, G.; Miller, D. D. Synthesis and pharmacological evaluation of second-generation phosphatidic acid derivatives as lysophosphatidic acid receptor ligands. Bioorg. Med. Chem. Lett. 2006, 16, 633640.

166. Albers, H. M.; van Meeteren, L. A.; Egan, D. A.; van Tilburg, E. W.; Moolenaar, W. H.; Ovaa, H. Discovery and optimization of boronic acid based inhibitors of autotaxin. J. Med. Chem. 2010, 53, 4958-4967.

167. Albers, H. M.; Dong, A.; van Meeteren, L. A.; Egan, D. A.; Sunkara, M.; van Tilburg, E. W.; Schuurman, K.; van, T. O.; Morris, A. J.; Smyth, S. S.; Moolenaar, W. H.; Ovaa, H. Boronic acid-based inhibitor of autotaxin reveals rapid turnover of LPA in the circulation. Proc. Natl. Acad. Sci. U. S. A 2010, 107, 7257-7262.

168. Gajewiak, J.; Tsukahara, R.; Fujiwara, Y.; Tigyi, G.; Prestwich, G. D. Synthesis, pharmacology, and cell biology of sn-2-aminooxy analogues of lysophosphatidic acid. Org. Lett. 2008, 10, 1111-1114.

169. Gajewiak, J.; Tsukahara, R.; Tsukahara, T.; Fujiwara, Y.; Yu, S.; Lu, Y.; Murph, M.; Mills, G. B.; Tigyi, G.; Prestwich, G. D. Alkoxymethylenephosphonate analogues of (Lyso) phosphatidic acid stimulate signaling networks coupled to the LPA2 receptor. ChemMedChem. 2007, 2, 1789-1798.

170. Zhang, H.; Xu, X.; Gajewiak, J.; Tsukahara, R.; Fujiwara, Y.; Liu, J.; Fells, J. I.; Perygin, D.; Parrill, A. L.; Tigyi, G.; Prestwich, G. D. Dual activity lysophosphatidic acid receptor pan-antagonist/autotaxin inhibitor reduces breast cancer cell migration in vitro and causes tumor regression in vivo. Cancer Res. 2009, 69, 5441-5449.

171. Uchiyama, A.; Mukai, M.; Fujiwara, Y.; Kobayashi, S.; Kawai, N.; Murofushi, H.; Inoue, M.; Enoki, S.; Tanaka, Y.; Niki, T.; Kobayashi, T.; Tigyi, G.; MurakamiMurofushi, K. Inhibition of transcellular tumor cell migration and metastasis by novel carba-derivatives of cyclic phosphatidic acid. Biochim. Biophys. Acta 2007, $1771,103-112$.

172. Hoeglund, A. B.; Bostic, H. E.; Howard, A. L.; Wanjala, I. W.; Best, M. D.; Baker, D. L.; Parrill, A. L. Optimization of a pipemidic acid autotaxin inhibitor. J. Med. Chem. 2010, 53, 1056-1066.

173. Hoeglund, A. B.; Howard, A. L.; Wanjala, I. W.; Pham, T. C.; Parrill, A. L.; Baker, D. L. Characterization of non-lipid autotaxin inhibitors. Bioorg. Med. Chem. 2010, $18,769-776$. 
174. North, E. J.; Osborne, D. A.; Bridson, P. K.; Baker, D. L.; Parrill, A. L. Autotaxin structure-activity relationships revealed through lysophosphatidylcholine analogs. Bioorg. Med. Chem. 2009, 17, 3433-3442.

175. North, E. J.; Howard, A. L.; Wanjala, I. W.; Pham, T. C.; Baker, D. L.; Parrill, A. L. Pharmacophore development and application toward the identification of novel, small-molecule autotaxin inhibitors. J. Med. Chem. 2010, 53, 3095-3105.

176. Parrill, A. L.; Baker, D. L. Autotaxin inhibition: challenges and progress toward novel anti-cancer agents. Anticancer Agents Med. Chem. 2008, 8, 917-923.

177. Ferry, G.; Moulharat, N.; Pradere, J. P.; Desos, P.; Try, A.; Genton, A.; Giganti, A.; Beucher-Gaudin, M.; Lonchampt, M.; Bertrand, M.; Saulnier-Blache, J. S.; Tucker, G. C.; Cordi, A.; Boutin, J. A. S32826, a nanomolar inhibitor of autotaxin: discovery, synthesis and applications as a pharmacological tool. J. Pharmacol. Exp. Ther. 2008, 327, 809-819.

178. Kim, Y. C.; Brown, S. G.; Harden, T. K.; Boyer, J. L.; Dubyak, G.; King, B. F.; Burnstock, G.; Jacobson, K. A. Structure-activity relationships of pyridoxal phosphate derivatives as potent and selective antagonists of P2X1 receptors. $J$. Med. Chem. 2001, 44, 340-349.

179. Jiang, G.; Xu, Y.; Fujiwara, Y.; Tsukahara, T.; Tsukahara, R.; Gajewiak, J.; Tigyi, G.; Prestwich, G. D. Alpha-substituted phosphonate analogues of lysophosphatidic acid (LPA) selectively inhibit production and action of LPA. ChemMedChem. 2007, 2, 679-690.

180. Valentine, W. J.; Kiss, G. N.; Liu, J.; E S; Gotoh, M.; Murakami-Murofushi, K.; Pham, T. C.; Baker, D. L.; Parrill, A. L.; Lu, X.; Sun, C.; Bittman, R.; Pyne, N. J.; Tigyi, G. (S)-FTY720-vinylphosphonate, an analogue of the immunosuppressive agent FTY720, is a pan-antagonist of sphingosine 1-phosphate GPCR signaling and inhibits autotaxin activity. Cell Signal. 2010, 22, 1543-1553.

181. Imamura, F.; Horai, T.; Mukai, M.; Shinkai, K.; Akedo, H. Serum requirement for in vitro invasion by tumor cells. Jpn. J. Cancer Res. 1991, 82, 493-496.

182. Imamura, F.; Horai, T.; Mukai, M.; Shinkai, K.; Sawada, M.; Akedo, H. Induction of in vitro tumor cell invasion of cellular monolayers by lysophosphatidic acid or phospholipase D. Biochem. Biophys. Res. Commun. 1993, 193, 497-503.

183. Mukai, M.; Imamura, F.; Ayaki, M.; Shinkai, K.; Iwasaki, T.; MurakamiMurofushi, K.; Murofushi, H.; Kobayashi, S.; Yamamoto, T.; Nakamura, H.; Akedo, H. Inhibition of tumor invasion and metastasis by a novel lysophosphatidic acid (cyclic LPA). Int. J. Cancer 1999, 81, 918-922. 
184. Mukai, M.; Nakamura, H.; Tatsuta, M.; Iwasaki, T.; Togawa, A.; Imamura, F.; Akedo, H. Hepatoma cell migration through a mesothelial cell monolayer is inhibited by cyclic AMP-elevating agents via a Rho-dependent pathway. FEBS Lett. 2000, 484, 69-73.

185. Altman, M. K.; Gopal, V.; Jia, W.; Yu, S.; Hall, H.; Mills, G. B.; McGinnis, A. C.; Bartlett, M. G.; Jiang, G.; Madan, D.; Prestwich, G. D.; Xu, Y.; Davies, M. A.; Murph, M. M. Targeting melanoma growth and viability reveals dualistic functionality of the phosphonothionate analogue of carba cyclic phosphatidic acid. Mol. Cancer 2010, 9, 140.

186. Gierse, J.; Thorarensen, A.; Beltey, K.; Bradshaw-Pierce, E.; Cortes-Burgos, L.; Hall, T.; Johnston, A.; Murphy, M.; Nemirovskiy, O.; Ogawa, S.; Pegg, L.; Pelc, M.; Prinsen, M.; Schnute, M.; Wendling, J.; Wene, S.; Weinberg, R.; Wittwer, A.; Zweifel, B.; Masferrer, J. A novel autotaxin inhibitor reduces lysophosphatidic acid levels in plasma and the site of inflammation. J. Pharmacol. Exp. Ther. 2010, 334, 310-317.

187. Prestwich, G. D.; Xu, Y.; Qian, L.; Gajewiak, J.; Jiang, G. New metabolically stabilized analogues of lysophosphatidic acid: agonists, antagonists and enzyme inhibitors. Biochem. Soc. Trans. 2005, 33, 1357-1361.

188. Jansen, S.; Andries, M.; Vekemans, K.; Vanbilloen, H.; Verbruggen, A.; Bollen, M. Rapid clearance of the circulating metastatic factor autotaxin by the scavenger receptors of liver sinusoidal endothelial cells. Cancer Lett. 2009, 284, 216-221.

189. Durgam, G. G.; Virag, T.; Walker, M. D.; Tsukahara, R.; Yasuda, S.; Liliom, K.; van Meeteren, L. A.; Moolenaar, W. H.; Wilke, N.; Siess, W.; Tigyi, G.; Miller, D. D. Synthesis, structure-activity relationships, and biological evaluation of fatty alcohol phosphates as lysophosphatidic acid receptor ligands, activators of PPARgamma, and inhibitors of autotaxin. J. Med. Chem. 2005, 48, 4919-4930.

190. Kitayama, J.; Shida, D.; Sako, A.; Ishikawa, M.; Hama, K.; Aoki, J.; Arai, H.; Nagawa, H. Over-expression of lysophosphatidic acid receptor-2 in human invasive ductal carcinoma. Breast Cancer Res. 2004, 6, R640-R646.

191. Hope, J. M.; Wang, F. Q.; Whyte, J. S.; Ariztia, E. V.; Abdalla, W.; Long, K.; Fishman, D. A. LPA receptor 2 mediates LPA-induced endometrial cancer invasion. Gynecol. Oncol. 2009, 112, 215-223.

192. Jeong, K. J.; Park, S. Y.; Seo, J. H.; Lee, K. B.; Choi, W. S.; Han, J. W.; Kang, J. K.; Park, C. G.; Kim, Y. K.; Lee, H. Y. Lysophosphatidic acid receptor 2 and $\mathrm{Gi} / \mathrm{Src}$ pathway mediate cell motility through cyclooxygenase 2 expression in CAOV-3 ovarian cancer cells. Exp. Mol. Med. 2008, 40, 607-616. 
193. Shida, D.; Kitayama, J.; Yamaguchi, H.; Hama, K.; Aoki, J.; Arai, H.; Yamashita, H.; Mori, K.; Sako, A.; Konishi, T.; Watanabe, T.; Sakai, T.; Suzuki, R.; Ohta, H.; Takuwa, Y.; Nagawa, H. Dual mode regulation of migration by lysophosphatidic acid in human gastric cancer cells. Exp. Cell Res. 2004, 301, 168-178.

194. Yamashita, H.; Kitayama, J.; Shida, D.; Ishikawa, M.; Hama, K.; Aoki, J.; Arai, H.; Nagawa, H. Differential expression of lysophosphatidic acid receptor-2 in intestinal and diffuse type gastric cancer. J. Surg. Oncol. 2006, 93, 30-35.

195. Zhao, Y.; Tong, J.; He, D.; Pendyala, S.; Evgeny, B.; Chun, J.; Sperling, A. I.; Natarajan, V. Role of lysophosphatidic acid receptor LPA2 in the development of allergic airway inflammation in a murine model of asthma. Respir. Res. 2009, 10, 114.

196. Deng, W.; Shuyu, E.; Tsukahara, R.; Valentine, W. J.; Durgam, G.; Gududuru, V.; Balazs, L.; Manickam, V.; Arsura, M.; VanMiddlesworth, L.; Johnson, L. R.; Parrill, A. L.; Miller, D. D.; Tigyi, G. The lysophosphatidic acid type 2 receptor is required for protection against radiation-induced intestinal injury. Gastroenterology 2007, 132, 1834-1851.

197. Beck, H. P.; Kohn, T.; Rubenstein, S.; Hedberg, C.; Schwandner, R.; Hasslinger, K.; Dai, K.; Li, C.; Liang, L.; Wesche, H.; Frank, B.; An, S.; Wickramasinghe, D.; Jaen, J.; Medina, J.; Hungate, R.; Shen, W. Discovery of potent LPA2 (EDG4) antagonists as potential anticancer agents. Bioorg. Med. Chem. Lett. 2008, 18, 1037-1041.

198. Mark Johnson; Gerry Maggiora. Concepts and Applications of Molecular Similarity. 1-9-1990. Wiley, New York.

199. Karakoc, E.; Cherkasov, A.; Sahinalp, S. C. Distance based algorithms for small biomolecule classification and structural similarity search. Bioinformatics. 2006, 22, e243-e251.

200. Trotter, K. D.; Reglinski, J.; Robertson, K.; Forgie, J. C.; Parkinson, J. A.; Kennedy, A. R.; Armstrong, D. R.; Sowden, R. J.; Spickett, C. M. Structural studies of trans-N2S2 copper macrocycles. Inorganica Chimica Acta 2009, 362, 4065-4072. 


\section{Vita}

Renuka Gupte was born in India in 1981. She finished her bachelor's degree in pharmaceutical sciences in 2003. After receiving her degree, she worked with Dr. M.S. Bhatia and Dr. S.L Bodhankar on projects in medicinal chemistry and pharmacology from year 2003-2004. In fall 2005 she was accepted at the University of Tennessee as a graduate student in the Ph.D. program (Major: Pharmaceutical Sciences). 